An Integrated Analysis of Resilience:

How to Achieve Positive Outgrowths 
(C) Isabella Meneghel, 2014

(c) Cover: Isabella Meneghel, 2014. 


\title{
An Integrated Analysis of Resilience: How to Achieve Positive Outgrowths
}

\author{
Isabella Meneghel \\ Departamento de Psicología Evolutiva, Educativa, \\ Social y Metodología

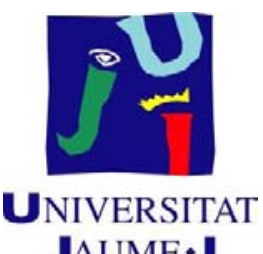 \\ JAUME+I
}

2 de Octubre de 2014

Directoras:

Prof. Dr. Marisa Salanova Soria Dr. Isabel Martínez Martínez 
The current dissertation project was funded by the Universitat Jaume I (PREDOC/2009/54), Spanish Ministry of Economy and Competitiveness (\#PSI2011-22400), Fundació Caixa Castelló-Bancaixa (\#E-2012-22), Fundació Caixa Castelló-Bancaixa (\#E 2013-31), and Consellería de Educación Generalitat Valenciana - Programa Prometeo (PROMETEO/2013/ 025). 
ATE. 

No te rindas que la vida es eso, continuar el viaje, perseguir tus sueños, destrabar el tiempo, correr los escombros y destapar el cielo.

(M. Benedetti) 



\section{An Integrated Analysis of Resilience: \\ How to Achieve Positive Outgrowths}

\begin{tabular}{|c|c|c|}
\hline & Contents & Page \\
\hline Foreword & Prólogo & 11 \\
\hline Chapter 1 & General Introduction & 13 \\
\hline Chapter 2 & $\begin{array}{l}\text { El Camino de la Resiliencia Organizacional - Una revisión teórica } \\
\text { [The Road of Organizational Resilience - A Theoretical Review] }\end{array}$ & 23 \\
\hline Chapter 3 & $\begin{array}{l}\text { J ob-Related Antecedents of Team Resilience and Improved } \\
\text { Performance }\end{array}$ & 51 \\
\hline Chapter 4 & $\begin{array}{c}\text { Feeling Good makes us Stronger: How Team Resilience Mediates } \\
\text { the effect of Positive Emotions on Team Performance }\end{array}$ & 69 \\
\hline Chapter 5 & $\begin{array}{l}\text { How to promote Academic Satisfaction and Performance: } \\
\text { Building Academic Resilience through Coping Strategies }\end{array}$ & 87 \\
\hline Chapter 6 & $\begin{array}{l}\text { Social Context and Resilience as Predictors of J ob Satisfaction } \\
\text { and Performance: A Multilevel Study over time }\end{array}$ & 113 \\
\hline Chapter 7 & General Conclusions & 135 \\
\hline References & & 151 \\
\hline Summaries & Resumen en español - Riassunto in italiano & 181 \\
\hline $\begin{array}{l}\text { Acknowledge } \\
\text { ments }\end{array}$ & Agradecimientos & 185 \\
\hline
\end{tabular}





\section{PRÓLOGO}

Durante los últimos meses de la elaboración de esta tesis, un día, al azar, me encontré con el concepto de kintsukuroi, palabra en japonés que hace referencia al arte tradicional nipón de la "reparación de oro". Cuando los japoneses reparan objetos rotos, enaltecen la zona dañada rellenando las grietas con oro. Ellos creen que cuando algo ha sufrido un daño y tiene una historia, se vuelve más hermoso. En lugar de tratar de ocultar los defectos y grietas, estos se acentúan y celebran, ya que ahora se han convertido en la parte más fuerte y apreciable de la pieza. El resultado es que el objeto no sólo queda reparado, sino que es aún más fuerte y más bello por haber estado roto.

Me quedé fascinada, ¡cuánta analogía con el concepto de resiliencia! Y, de pronto, entendí que esta había sido la motivación de mi tesis, la razón última de este trabajo: aportar mi granito de arena en la comprensión de cómo las personas en las organizaciones son capaces de enfrentarse a la adversidad y rellenar las grietas que aparecen con oro, para acentuar y celebrar lo más fuerte y bello que llevan dentro. Sin saberlo, esto ha sido lo que me ha movido a dar mis primeros pasos en el mundo de la investigación, a emprender el camino desde la trayectoria de la Psicología Positiva.

Llegado el final de la elaboración de la tesis, sé con seguridad que sólo se trata de un punto y seguido. "An Integrated Analysis of Resilience: How to Achieve Positive Outgrowths" no ha sido más que el principio de un largo camino, empezado con alguna vacilación hace 5 años y con un final aún impredecible, pero ciertamente lleno de ilusión y satisfacciones. A lo largo del trabajo que he realizado, espero haber sido capaz de reflejar todo esto y, además del conocimiento generado, compartir mi entusiasmo con el lector que ahora tiene entre sus manos esta tesis.

Tutto il resto era ancora nulla.

Inventarlo - questo sarebbe stato meraviglioso.

(A. Baricco) 


\section{CHAPTER 1}

\section{General Introduction}

Since late 2008 a global recession has upset the entire European economy and, although not all European countries have experienced the economic downturn or statelevel financial problems to the same extent, the economic and financial crisis is affecting working conditions all around Europe in different ways and with a varying scope. In accordance with the European Foundation for the Improvement of Living and Working Conditions (2013), the pattern is one of less work, reduced overall working time, less overtime, rising job insecurity, less choice for workers, wage freezes and wage cuts. There is also greater work intensity, deterioration of work-life balance, increasing stress at work, growth in the informal economy and changes in migration patterns. The impact of the crisis on the EU countries has varied from country to country, those in Southern and Eastern Europe together with Ireland being the ones that report the greatest effects of the crisis. In addition to changes in working conditions, some European countries have also made changes to their legislation on employment protection, such as the Spanish Law of 2012, which increase job stress and insecurity among employees. Indeed, despite the existence of some differences among the European countries, during the crisis years a general tendency toward increasing job insecurity can be observed $(+4.51 \%$; European Foundation for the Improvement of Living and Working Conditions, 2013) and about 20\% of workers report that their mental health in the workplace is at risk (Eurofound, 2012).

These concerns are particularly important given that the European policy agenda up to 2020 is faced with the challenge of maintaining and promoting the health and wellbeing of its human resources. However, in the current economic environment, most organizations are apparently depleting rather than developing human resources by putting workers under great pressure (Tsui, 2013). Research extensively showed that a perceived high level of stress is connected with undesirable organizational outcomes, such as depression, emotional exhaustion, job dissatisfaction, absenteeism, tardiness, reduced turnover, reduced quality and quantity in job performance, counterproductive behavior, accidents, higher health care costs, and low motivation (De Lange, Taris, Kompier, Houtman, \& Bongers, 2004; Morris, Messal, \& Meriac, 2013). In seeking ways to help employees navigate the stressful and ever-challenging work environment, 
it is fundamental to concentrate on developing strengths and capacities in human resources, as well as to recognize the importance of positivity (Avey, Luthans, \& Jensen, 2009). In fact, they face challenges and adversity in organizations on a regular, even daily, basis, and thus it is fundamental for them to manage to absorb the stress that arises from these challenges, and not only to return functioning to a "normal" level but also to learn and grow from adversity in order to emerge stronger than before (Stephens, Heaphy, Carmeli, Spreitzer, \& Dutton, 2013; Sutcliffe \& Vogus, 2003).

Given the characteristics of the current environment, is it possible that some organizations, as well as the individuals and groups of which they are composed, successfully adjust and thrive amidst these conditions? Would it be feasible to enhance the process of overcoming and thriving despite demanding and stressful conditions? If so, what helps the organization and its members in this process? To answer these questions, we propose resilience as a key process that provides insight into how organizations continually achieve desirable outcomes in the midst of adversity, strain, and significant barriers to adaptation or development. For this reason, the importance of resilience in the organizational context will be introduced in the following.

\section{The value of resilience}

The relevance of studying resilience at present is proven by the greater presence it has gained in scientific (peer-reviewed) publications. At the time of writing, the PsycINFO database returns 5209 records pertaining to "resilience", whereas in 2000 a search yielded only 383. Moreover, the number of records in peer-reviewed journals for "organizational resilience" increased from 6 records in 2000 to 144 records at this time. It is obvious that, especially during the last few years of the economic and financial crisis, the concept has increased in popularity and expanded its use and conceptualization to different contexts, such as the organizational one. In fact, in a turbulent, surprising, continuously evolving environment, organizations must often be able to move beyond survival to prosper and thrive (Lengnick-Hall, Beck, \& LengnickHall, 2011). In this sense, recent calls have been made to address the potential role of resilience in order to impact functioning and outcomes in demanding and adaptive circumstances (Kaplan, Laport, \& Waller, 2013).

As the number of studies on resilience has grown, so has the discrepancy in the conceptualizations of resilience as a personal trait versus a dynamic process, often leading to confusion between resiliency as a personality trait (derived from ego- 
resiliency) and resilience as a process (Luthar, Cicchetti, \& Becker, 2000). In accordance with these scholars, we refer to resilience as a dynamic process encompassing positive adaptation within the context of significant adversity. Specifically in the domain of organizations, the concept of resilience has been used to refer to relatively ordinary adaptive processes when encountering unexpected and adverse conditions that result either from large-scale disturbances or the accumulation of several minor disruptions (Sutcliffe \& Vogus, 2003). The resilience approach recognizes the need for flexibility, adaptation, and improvisation in situations characterized by change and uncertainty, as well as the need to find inner strengths and resources in order to cope effectively (Ganor \& Ben-Lavy, 2003; Youssef \& Luthans, 2007). What is more, previous studies proposed that resilience readies and enables individuals, teams, and organizations to respond positively to adverse conditions and to emerge strengthened (Sutcliffe \& Vogus, 2003).

In this regard, resilience must help organizations, as well as their members and teams, to deal with adverse and stressful situations, so that they can be overcome and positive organizational outcomes can be achieved. However, given that in the past research on resilience was mainly related to the developmental and clinical context, and interest in resilience in the organizational context is quite recent, more scientific research is still necessary to clarify several relevant issues concerning resilience in the organization; some of them are addressed through the research challenges dealt with in the current work.

\section{Challenges for resilience research}

This dissertation attempts to contribute to resilience research by attempting to answer some fundamental research questions. They were grouped into three specific research challenges that will serve as a general outline for the primary objectives of the dissertation.

CHALLENGE 1. How can resilience be conceptualized in the organizational context? Besides the traditional focus on individual resilience, is it worth focusing on team or group resilience?

Since individuals represent the most immediate context for examining processes and characteristics, the first steps in research into resilience in the organizational context were focused on the individual level of analysis, i.e., employees' resilience. Nowadays, individuals face challenges and adversity in organizations on a regular basis, and the 
increasing levels of stress and decreasing amounts of recovery time experienced by the members of organizations point to the importance of the development of resilience (Luthans, Vogelgesang, \& Lester, 2006).

Nevertheless, the pressures of global competition, the need to consolidate business models in complex and shifting environments, and the pursuit of continuous innovation have also led to an appraisal of the team as a key element of the basic organizational architecture (Kozlowski \& Bell, 2003). In this context, the joint actions of individuals working together to attain shared goals are viewed as essential to be able to achieve effectiveness and competitive advantage. In many modern organizations, teams have become the method of choice for responding quickly, flexibly and adaptively to technological and market changes, and therefore for improving the organization's chances of survival (Gil, Alcover, \& Peiró, 2005; Richter, West, van Dick, \& Dawson, 2006). Thus, in the same way that organizations are focusing increasingly more on the role and performance of their teams, attention will be directed toward identifying the characteristics and processes that elicit the synergistic benefits team-based work structures are assumed to offer (West, Patera, \& Carsten, 2009), such as team resilience. However, despite its relevance, little research has been conducted on the subject of team resilience (e.g., Bennett, Aden, Broome, Mitchell, \& Rigdon, 2010; West et al., 2009). Extending this line of research would help to improve our knowledge of how both individual and team resilience can make a significant contribution in the organizational context.

CHALLENGE 2. What are the antecedents of resilience in the organizational context? In addition to dispositional antecedents, are there any situational features that help to enhance resilience? Can the antecedents be conceptualized at different levels?

Given the increased consideration attributed to resilience in the organizational context, it is remarkable to see how little attention has been paid to identifying what factors can be considered the antecedents of resilience. Although it is relative, emerging and changing in transaction with specific circumstances and challenges (Staudinger, Marsiske, \& Baltes, 1993), resilience developed and displayed in a certain situation will lead to better preparation for upcoming events (Egeland, Carlson, \& Sroufe, 1993). Therefore, establishing what variables help influence resilience in the organizational context is essential to better prepare responses to future adverse situations. In recent years, scholars have begun to identify some potential factors, but they usually came 
from evidence in clinical or developmental settings and are focused at the individual level. Thus, systematic evidence about the antecedents of resilience in the organizational setting is still lacking.

In order to delineate the specific antecedents that are associated with resilience in the organizational context, it is important to differentiate between two streams of work. First, an important step toward an adequate identification of the antecedents of resilience in organizational contexts is to give more attention to situational features that, jointly with the dispositional ones, can influence resilience. Second, attention will be paid to multilevel antecedents of resilience, thereby going beyond the traditional focus at the individual-level of analysis and taking into consideration team-level factors. Both lines of study should be a very welcome addition to resilience research because they will present a number of potential applications and encourage organizational interventions to increase these sources of resilience, particularly in the context of the current economic crisis, and bounce back from setbacks feeling more resourceful and strengthened and able to continue to thrive.

CHALLENGE 3. What is the real impact of resilience in the organizational context? Does it count in order to achieve better performance?

Undoubtedly, performance is the most widely studied criterion variable in the literature on organizational behavior and human resource management (Bommer, Johnson, Rich, Podsakoff, \& MacKenzie, 1995). Despite the great theoretical interest in linking resilience to performance in the organizational context (Sutcliffe \& Vogus, 2003), to our knowledge the nature of their relationship is mainly speculative and only a few studies provide empirical evidence of any link between them (i.e., Luthans, Avolio, Walumbwa, \& Li, 2005). This initial evidence notwithstanding, there has been no systematic investigation into the resilience-performance relationship. Although the proposition that individual performance could be increased by resilience seems legitimate, additional research is necessary to determine the true performance boundary of resilience.

Furthermore, given that many organizations are adopting team-based structures in which teams are responsible for key organizational outputs instead of relying on functional structures (Beyerlein, Johnson, \& Beyerlein, 1995; McDermott, 1999), organizations are focusing increasingly more frequently on the performance of their teams (Gully, Incalcaterra, Joshi, \& Beaubien, 2002). Recent calls for deeper 
examination of the potential role of variables that may have an impact on team performance in crisis scenarios refer to resilience as a possible candidate (Kaplan et al., 2013). In this regard, Driskell and Salas (1991) emphasized the importance of understanding team performance during stressful situations for at least two reasons: (a) the complexity and variety of the tasks they are required to do often call for team efforts; and (b) team processes affect team outcomes as much as individual processes. However, a theoretical perspective and empirical evidence of the resilience-performance relationship at the team level is still lacking.

Hence, research on the resilience-performance relationship is in need of a new theoretical perspective and empirical evidence in order to gain a deeper understanding of the process that underlies the effect of resilience on performance. Likewise, it also need to be studied over time with the use of different sources to reduce the risk of suffering from common method variance (Podsakoff, MacKenzie, Lee, \& Podsakoff, 2003) and thus obtain more accurate results.

\section{Outline of the dissertation}

The present dissertation aims to advance our current understanding of resilience in the organizational context by shedding light on its antecedents and consequences at different levels of analysis. To this end, an opening theoretical review chapter (Chapter 2) and four empirical studies were designed to address the previously discussed research challenges and questions. Whereas the first two empirical studies (Chapters 3 and 4) goes deeper on resilience conceptualized at the team level (i.e., team resilience), in the last two empirical studies (Chapters 5 and 6) the focus was shifted to the resilience of individuals that composed organizations (i.e., individual resilience). Table 1.1 provides an overview of the challenges addressed by each empirical study. Subsequently, the outline of the dissertation, in terms of the content of each chapter, along with its main objectives and hypotheses, is presented. 
Table 1.1

Overview of research challenges targeted in the chapters of the dissertation

\begin{tabular}{|c|c|c|c|c|c|}
\hline \multirow[b]{3}{*}{$\begin{array}{c}\text { Challenge } \\
1\end{array}$} & \multirow[b]{3}{*}{$\begin{array}{l}\text { Resilience at the individual level } \\
\text { Resilience at the team level }\end{array}$} & \multicolumn{4}{|c|}{ Chapters - empirical studies } \\
\hline & & 3 & 4 & 5 & 6 \\
\hline & & $\mathrm{X}$ & $\mathrm{X}$ & $\mathrm{X}$ & $\mathrm{X}$ \\
\hline \multirow{4}{*}{$\begin{array}{c}\text { Challenge } \\
2\end{array}$} & Dispositional antecedents & & $\mathrm{X}$ & $X$ & \\
\hline & Situational antecedents & $\mathrm{X}$ & & & $\mathrm{X}$ \\
\hline & Individual-level antecedents & & & $X$ & \\
\hline & Team-level antecedents & $\mathrm{X}$ & $\mathrm{X}$ & & $\mathrm{X}$ \\
\hline $\begin{array}{c}\text { Challenge } \\
3\end{array}$ & $\begin{array}{l}\text { Impact on individual performance } \\
\text { Impact on team performance }\end{array}$ & $\mathrm{X}$ & $X$ & $\mathrm{X}$ & $\mathrm{X}$ \\
\hline
\end{tabular}

Chapter 2, entitled 'The Road of Organizational Resilience - A Theoretical Review' is, as its name suggests, a theoretical chapter and presents a systematic overview of the state of the art of resilience research in the organizational context. Although this overview is not meant to be in any way exhaustive, several aspects of resilience research are addressed and it comprises critical issues that have been raised by such research throughout the past decades. Taking its conceptualization as the starting point, the definition of resilience is provided together with its relationship with similar constructs and theoretical frameworks. Antecedents and consequences are then outlined and the main measurements of resilience are reviewed. Moreover, some of the knowledge gaps in resilience research are highlighted along with the conclusion of this chapter, which is the theoretical starting point of this thesis and guides the following four empirical studies.

Chapter 3, entitled 'The Emergence of Team Resilience: Job Related Antecedents and Improved Team Performance', is the first empirical chapter of the present dissertation. In this study, the role of job-related antecedents of team resilience is examined and, in accordance with the taxonomy proposed by the Job DemandsResources Model (JD-R; Demerouti, Bakker, Nachreiner, \& Schaufeli, 2001), the additive and moderating effects of collective job demands and job social resources on team resilience are investigated. Furthermore, the mediating role of team resilience in the relationships between job-related variables and team performance is tested. To 
accomplish this aim, data from 275 work-teams $(\mathrm{N}=1633$ employees) belonging to 52 Spanish organizations are taken into account.

Chapter 4, entitled 'Feeling Good makes us Stronger: How Team Resilience Mediates between Positive Emotions and Team Performance', delves deeper into the role played by collective positive emotions in increasing team resilience. According to the Broaden-and-Build Theory of positive emotions (Fredrickson, 1998; 2001) and taking a step further toward its application at the team level, the predictive role of collective positive emotions on team resilience is examined. Moreover, the mediation role of team resilience between collective positive emotions and team performance as rated by the direct supervisor is tested. In order to test the relationships proposed, data from 216 work-teams $(\mathrm{N}=1076$ employees $)$ and their supervisors in 40 Spanish organizations are used.

Chapter 5, entitled 'How to promote Academic Satisfaction and Performance: Building Academic Resilience through Coping Strategies', is focused on resilience in the academic context in order to know how the organizations of learning, as universities, can support the resilience of its students. The chapter has a twofold aim. Firstly, the validation of an academic resilience scale (Martin \& Marsh, 2006) is performed in a Spanish sample. Secondly, the extent to which different coping strategies impact on academic resilience is examined, with evidence being provided about what kind of strategies - organized into theoretical and empirical based categories - are positively or negatively related with resilience. Moreover, the relationship between academic resilience and objective performance over time is explored, giving evidence that this relationship is mediated by academic satisfaction. To test our hypothesized model, a sample of 870 university students from a Spanish University is considered and a two-wave longitudinal design is used.

Chapter 6, entitled 'Social Context and Resilience as Predictors of Job Satisfaction and Performance: A Multilevel Study over time' is the last empirical study of this dissertation. In this chapter, whether individual work resilience is affected by a variable at a different and higher (work-unit) level is explored, taking into consideration work-units' shared perceptions of social context (Borgogni, Dello Russo, Di Tecco, Alessandri, \& Vecchione, 2011). Furthermore, both individual work resilience and work-units' shared perceptions of social context are examined as antecedents of individual job satisfaction and objective performance over time. Using a two-wave 
longitudinal design, data are collected from 305 employees nested in 67 work-units of a large Italian organization.

Finally, Chapter 7 comprises some overall conclusions from the preceding chapters included in the present dissertation. In this chapter, the most salient results with which to address the previously discussed research challenges and questions are summarized. In doing so, this chapter aims to integrate and discuss the key findings and main contributions of this dissertation, with special attention to research challenges and practical implications. In addition, it identifies the limitations of the studies presented and avenues for future research on resilience. 


\section{CHAPTER 2}

\section{El camino de la Resiliencia Organizacional - Una revisión teórica ${ }^{1}$}

(The Road of Organizational Resilience - A Theoretical Review)

\section{Resumen}

En este trabajo se ha realizado una revisión teórica del concepto de resiliencia en el contexto organizacional, con el objetivo de examinar los estudios empíricos que se han desarrollado en los últimos años para determinar el statu quo del constructo y aclararlo conceptualmente. En primer lugar, se abordan cuestiones como la definición de resiliencia en un intento de aclarar la naturaleza, el alcance y la estructura del constructo. La distinción entre los diferentes niveles de análisis de la resiliencia es un tema de interés y las investigaciones recientes realizadas a nivel individual, de equipo y organizacional han producido aportaciones valiosas en este sentido. De manera sintética se presentan los resultados de la investigación, que ponen de manifiesto cómo la resiliencia está relacionada con una variedad de antecedentes (p. ej. emociones positivas) y consecuencias (p. ej. desempeño), tanto a nivel de análisis individual como agregado, así como los modelos heurísticos de resiliencia organizacional (p. ej. modelo HERO). Por último, se plantean cuestiones por resolver como posibles directrices futuras de investigación sobre resiliencia en la psicología del trabajo y de las organizaciones.

Palabras clave: Resiliencia, Resiliencia Organizacional, Revisión Teórica

\footnotetext{
${ }^{1}$ Chapter 2 is based on: Meneghel, I., Salanova, M., \& Martínez, I. M. (2013). El camino de la Resiliencia Organizacional - Una revisión teórica. Aloma: Revista de Psicologia, Ciències de l'Educació i de l'Esport, 31(2), 13-24.
} 


\section{Introducción}

En un contexto de crisis económico-financiera mundial como la actual, las organizaciones suelen reflexionar más acerca de los resultados finales en términos de mercado o economía que en términos de procesos, decisiones y conductas que dan lugar a dichos resultados. Los comportamientos, tanto individuales como colectivos, que favorecieron o pudieron evitar la crisis pasan generalmente a un segundo plano pero cómo se interpreta la crisis y se responde a ella puede ser una fuente de aprendizaje y fortalecimiento para la organización (Choi, Sung, \& Kim, 2010). Dado que los estímulos estresantes son inevitables en el día a día, la diversidad de respuestas a estos estímulos se tiene que indagar en las diferentes disposiciones y procesos dirigidos a la busqueda del bienestar. El deterioro en términos de calidad de vida, de estrés laboral, de sacrificio personal y familiar (Stephens, Heaphy, Carmeli, Spreitzer, \& Dutton, 2013) así como el incremento del desempleo (Fleig-Palmer, Luthans, \& Mandernach, 2009), por citar algunas peculiaridades, conlleva un mayor grado de complejidad y esfuerzos a la hora de orientar comportamientos y procesos con el fin de vencer las dificultades y generar resultados positivos.

Sin embargo, a pesar de que hoy en día todas las empresas están afectadas de manera importante por la crisis contingente, no todas han respondido o están respondiendo de la misma manera. La razón es que las organizaciones modernas están cambiando en una dirección que se basa cada vez más en el conocimiento psicológico, la experiencia y el talento, así como en la autogestión y la atención a necesidades individuales y colectivas de los empleados, de la organización y de la sociedad en general (Salanova, 2009). Como consecuencia, cabría esperar que algunas empresas salieran de esta crisis resistentes y fuertes, mientras que otras podrían debilitarse e incluso quebrar. En toda esta amalgama de posibilidades entendemos que aquellas organizaciones que mantengan una notable tendencia a renovar y hacerse más fuertes en medio de la crisis se podrían considerar organizaciones resilientes (Salanova, Llorens, Cifre, \& Martínez, 2012).

En términos generales, con el concepto de resiliencia se hace referencia al logro y la conservación de una adaptación positiva en situaciones adversas. Se trata de un proceso que permite a las organizaciones, y a las personas y grupos que las conforman, evitar las tendencias no adaptativas y enfrentarse de manera positiva con lo inesperado (Sutcliffe \& Vogus, 2003). Asimismo, la resiliencia se determina como el proceso a través del cual las organizaciones logran absorber cambios y rupturas, tanto internos 
como externos, sin que por ello se vea afectada su rentabilidad, y llegando incluso a desarrollar una capacidad para, a través de procesos de rápida adaptación, lograr obtener beneficios extras derivados de las circunstancias imprevistas y adversas (Minolli, 2005). Esto es, el estudio de la resiliencia debería dar algunas explicaciones de por qué hay unas organizaciones que, a pesar de las dificultades, dan respuestas positivas con mayor facilidad y por qué resurgen de estas dificultades fortalecidas y con mayor contundencia en sus acciones y resultados (Salanova et al., 2012).

El objetivo del presente trabajo es incidir en los aspectos más destacados de la investigación sobre resiliencia organizacional, efectuando una revisión teórica en el ámbito de la psicología del trabajo y de las organizaciones, a la vez que identificando, a partir de sus resultados, directrices futuras de investigación.

\section{Conceptualización de resiliencia}

La palabra resiliencia deriva del latín resilire, término que significa 'volver atrás, volver a la posición original, resaltar y rebotar'. Es un concepto que procede de la física, donde hace referencia a la capacidad de un material de recobrar su forma original y volver al estado de equilibrio después de someterse a una presión deformadora.

El origen del estudio de la resiliencia en el ámbito de la psicología deriva fundamentalmente de los esfuerzos dirigidos a conocer la etiología y el desarrollo de la psicopatología, especialmente en niños con riesgo de desarrollar psicopatología debido a enfermedades mentales de los padres, conflictos interpersonales, pobreza o una combinación de éstos (Garmezy, 1971; 1974; Werner \& Smith, 1982). El análisis y el estudio sistemático de la resiliencia en los niños han dado la vuelta a muchos supuestos y modelos clásicos centrados en el déficit y en el problema, ya que sugieren que algunos de los supuestos originales sobre la resiliencia estaban, al menos en parte, equivocados. De hecho, los primeros estudios daban a entender que había algo extraordinario o especial en estos niños, a menudo descritos como invulnerables o invencibles. Sin embargo, la investigación ha mostrado evidencia de que la resiliencia es un proceso más normal y frecuente de lo que se pensaba (Masten, 2001).

\subsection{Definición}

En el ámbito de la psicología, a lo largo de los años, la resiliencia ha sido definida de maneras diferentes por parte de distintos autores, pero la mayoría de las definiciones coinciden en resaltar el proceso de adaptación frente a factores perturbadores, de estrés o adversidades. Así por ejemplo, Masten (2001) la define como una estrategia de 
afrontamiento y adaptación positiva frente a riesgos o adversidades significativas, mientras que Luthar, Cicchetti y Becker (2000) la definen como un proceso dinámico que abarca la adaptación positiva dentro del contexto de una adversidad significativa. La Asociación Americana de Psicología (APA, 2009) define la resiliencia como el proceso de adaptación exitosa frente a la adversidad, el trauma, la tragedia, las amenazas o las fuentes significativas de estrés, tales como problemas familiares o en las relaciones interpersonales, graves problemas de salud, así como situaciones de estrés a nivel laboral o financiero.

En general, existe un consenso sobre dos puntos clave: la resiliencia está considerada más como un proceso que como una habilidad, y está reconocida más como un proceso de adaptación específico en cada circunstancia que como una característica estable de la personalidad (Norris, Stevens, Pfefferbaum, Wyche, \& Pfefferbaum, 2008). Es decir, con el término resiliencia se hace referencia a un proceso dinámico que constituye la adaptación positiva en entornos adversos y desfavorables. Condiciones imprescindibles para que dicho proceso se manifieste son la exposición a situaciones amenazantes o adversidades intensas y el logro de una adaptación positiva (Luthar et al., 2000). Por lo tanto, para que se pueda hablar de organizaciones resilientes, las organizaciones deben estar sometidas a una amenaza o riesgo real; de hecho, por definición, sin amenaza no existe resiliencia.

El proceso de resiliencia se caracteriza por la utilización de medidas tanto reactivas como proactivas frente a las adversidades (Longstaff, 2005). Reactivas, porque la resiliencia reconoce que los fracasos, los traumas e incluso los acontecimientos positivos pueden tener un impacto destructivo, incluso en las personas más optimistas y positivas, y de ahí la necesidad de recuperarse. En este sentido, la resiliencia promueve el reconocimiento de este impacto, lo que permite que la persona afectada dedique tiempo, energía y recursos para recuperarse y rebotar, y volver a un punto de equilibrio. Por otro lado, la resiliencia favorece también una preparación de tipo más proactivo de cara a las dificultades, más potencial que responsiva, que tiene el objetivo de anticipar, estructurar y minimizar el impacto de los acontecimientos estresantes que se pueden presentar (Luthans, 2006). Con esa finalidad, la resiliencia proactiva se sirve de varias estrategias, como por ejemplo: la capacidad de toma de decisiones y el mantenimiento de una visión positiva (Riolli \& Savicki, 2003), la emocionalidad positiva provocada estratégicamente a través del uso del humor (Werner \& Smith, 1982), las técnicas de 
relajación (Demos, 1989; Wolin \& Wolin, 1993) y el pensamiento optimista (Kumpfer, 1999).

Finalmente hay que tener en cuenta que las experiencias previas afectan a las experiencias subsiguientes, de manera que la forma en la que una entidad (ya sea la organización, el grupo o la persona) interpreta y responde a los nuevos desafíos depende de las actitudes, las expectativas, los sentimientos y las posibilidades de respuesta derivados de las situaciones precedentes. Esto no pretende indicar que la resiliencia sea estable o que la resiliencia mostrada en cierta situación prediga de una manera determinista y lineal las respuestas resilientes posteriores. La resiliencia es dinámica, emergente y cambiante en relación con las circunstancias y los retos específicos; esto es, la resiliencia demostrada en una situación podría no ser mantenida en el tiempo o transferida a otras circunstancias o desafíos (Staudinger, Marsiske, \& Baltes, 1993). Pero se considera que la resiliencia manifestada en una o más situaciones concretas hace que la persona, el grupo o la organización en general esté más preparada para adaptarse al entorno y a las situaciones que pueden sobrevenir (Egeland, Carlson, \& Sroufe, 1993; Wildavsky, 1988). Con eso no solo se entiende que la organización sobrevive y prospera mediante el logro de un ajuste positivo ante la adversidad actual, sino también que en el proceso de responder fortalece su capacidad para poder adaptarse y prosperar en el futuro.

\subsubsection{Resiliencia individual}

Investigaciones recientes indican que para sobrevivir y prosperar en un contexto de cambio económico y social, las organizaciones necesitan tener empleados motivados y psicológicamente sanos (Salanova, 2008). Hoy en día, las personas se enfrentan a cambios constantes en su entorno laboral, tanto de tipo interno como externo, y la resiliencia podría mostrarse como el recurso clave a la hora de favorecer su adaptación y bienestar. Esto es, las personas resilientes están mejor equipadas para tratar con los estímulos estresantes de los entornos de trabajo constantemente cambiantes, a la vez que están más abiertas hacia nuevas experiencias, son más flexibles ante las demandas cambiantes y muestran mayor estabilidad emocional para afrontar situaciones estresantes (Tugade \& Fredrickson, 2004). En el ámbito laboral, por ejemplo, la resiliencia puede ayudar a los trabajadores a cumplir con las necesidades del cliente, a aprovechar las oportunidades que de otra manera podrían perderse, y a actuar con rapidez y eficacia en situaciones de amenaza y de crisis. 


\subsubsection{Resiliencia colectiva}

Debido a que las personas constituyen el contexto más tangible e inmediato para examinar las fortalezas personales, los pasos iniciales en el estudio de la resiliencia se han llevado a cabo principalmente a nivel individual. Sin embargo, teniendo en cuenta que los individuos están inevitablemente insertos en relaciones sociales (Bandura, 2000; Day, 2000), es razonable pensar que pueden experimentar una influencia importante por parte de algunos procesos grupales. Además, hoy en día los equipos o grupos de trabajo se han convertido en una pieza central de la estructura organizacional porque el trabajo colaborativo y en equipo es cada vez más importante de cara al desempeño global de la organización (West, Patera, \& Carsten, 2009). Por eso resulta interesante indagar el rol y la importancia de la resiliencia a nivel colectivo de grupos y equipos de trabajo.

En el contexto grupal, la resiliencia es definida como el proceso fundamental para proveer al equipo de las capacidades necesarias para rebotar ante fracasos, retrasos, conflictos o cualquier otra amenaza hacia el bienestar del propio equipo (West et al., 2009). La resiliencia colectiva puede, por lo tanto, ser considerada un proceso positivo significativo, puesto que contibuye a la reparación y recuperación de los grupos y equipos cuando se enfrentan a situaciones muy demandantes. Por eso es comprensible que en la investigación reciente se haya hecho hincapié en la necesidad de explorar el papel de las variables que pueden afectar el rendimiento del equipo en situaciones de crisis, sobre todo haciendo referencia al estudio de la resiliencia (Kaplan, Laport \& Waller, 2012).

\subsubsection{Resiliencia organizacional}

El desarrollo de la resiliencia organizacional no es fácil pero, en un entorno turbulento e inestable como el actual, la única ventaja competitiva que tienen las organizaciones es su capacidad para reinventar el modelo de negocio antes de que las circunstancias les obliguen a hacerlo (Hamel \& Välikangas, 2003). Cuando es resiliente, la empresa es capaz de tomar rápidamente ventaja y de anticiparse a las oportunidades o amenazas; las oportunidades son explotadas porque la organización está alerta y orientada a la acción y, en lugar de hacer frente a las oportunidades a través de análisis y observaciones, actúa (Salanova, 2009).

La resiliencia organizacional ha sido definida de manera diferente, pero similar, por parte de distintos autores. Wildavsky (1988) define la resiliencia organizacional como un proceso dinámico de adaptación de la organización que crece y se desarrolla con el tiempo, mientras que Diamond (1996) la define como la capacidad del sistema 
social de responder a los cambios. Finalmente, Lengnick-Hall y Beck (2003) definen la resiliencia organizacional como una mezcla compleja de comportamientos, perspectivas e interacciones que puede ser desarrollada, medida y dirigida.

Como se puede apreciar, de manera similar a lo que ocurre a nivel individual, en todas las definiciones, la resiliencia no es entendida como un atributo estático que las organizaciones poseen o no poseen. Más bien es el resultado de procesos que ayudan a las organizaciones a mantener los recursos de una forma suficientemente flexible, sostenible en el tiempo, almacenable, convertible y maleable como para evitar las tendencias menos adaptativas y hacer frente de manera positiva a lo inesperado.

\subsubsection{Resiliencia académica}

Una mención aparte merece el concepto de resiliencia académica. Las organizaciones del aprendizaje, es decir, las escuelas y universidades, se configuran como el contexto relevante para el desarrollo de la resiliencia académica. Numerosas investigaciones previas han señalado las similitudes que comparten los estudiantes y los empleados en sus respectivos contextos organizacionales, como por ejemplo, encontrarse en una estructura organizada jerárquicamente, deber trabajar en tareas definidas, saber gestionar múltiples actividades, cumplir plazos, trabajar de manera autónoma y también en grupo, así como hacer frente a niveles variables de control y apoyo social (Cotton, Dollard, \& de Jonge, 2002; Rode et al., 2005)

En el contexto académico, la definición de resiliencia es análoga a las que han sido señaladas anteriormente, ya que hace referencia al proceso que permite a los estudiantes lograr resultados exitosos a pesar de circunstancias adversas y desfavorables (Doll \& Lyon, 1998). Por tanto, los estudiantes que demuestran mayor resiliencia son aquellos que tienen altos niveles de desempeño a pesar de la presencia de eventos y condiciones estresantes (Leary \& De Rosier, 2012).

Los estudios que se ocupan de la resiliencia académica tienden a concentrarse en los grupos situados en condiciones adversas (ej., la pobreza y la violencia), bajo rendimiento crónico, específicas sub-poblaciones étnicas y la interacción entre etnia y el bajo rendimiento, así como los estudiantes con dificultades de aprendizaje (Martin \& Marsh, 2006; Morales, 2008). Por lo tanto, generalmente las investigaciones sobre resiliencia académica se refieren a un porcentaje relativamente pequeño de estudiantes y que experimentan una adversidad intensa. Sin embargo, la resiliencia académica es relevante para todos los estudiantes porque en algún momento todos pueden experimentar un cierto nivel de escaso rendimiento, de adversidad, cambios o tensiones. 


\subsection{Resiliencia y su relación con conceptos afines}

Existe en la literatura una discrepancia sobre la conceptualización de resiliencia porque es considerada por algunos autores como un rasgo de personalidad mientras que por otros como un proceso dinámico. La confusión sobre esta importante distinción es debida, al menos en parte, al concepto de ego-resiliency desarrollado por Block y Block (1980) y que se refiere a una característica personal del individuo. En su definición original, la ego-resiliency abarca un conjunto de rasgos que reflejan el ingenio en general, la solidez de carácter y la flexibilidad de funcionamiento en respuesta a las distintas circunstancias ambientales. Sin embargo, los conceptos de ego-resiliency y resiliencia difieren en dos dimensiones principales. En primer lugar, se entiende por ego-resiliency una característica de la personalidad del individuo, mientras que la resiliencia es un proceso de desarrollo dinámico. En segundo lugar, la ego-resiliency no supone la exposición efectiva a adversidades importantes, mientras que la resiliencia, por definición, lo hace.

Asimismo, es importante hacer referencia a la relación entre el concepto de resiliencia y el de hardiness, este último introducido en el campo de la medicina por Kobasa, Maddi y Kahn (1982). Los autores encontraron que había diferencias significativas entre personas expuestas a situaciones muy estresantes: mientras que algunas de ellas desarrollaban enfermedades, otras sentían bienestar; y atribuyeron estos cambios a una resistencia o fortaleza en la persona. Las diferencias entre los conceptos de resiliencia y hardiness son bastante borrosas, debido a que los dos conceptos están muy relacionados entre sí. Mientras autores como Bonanno (2004) sugiere que hardiness es una de las múltiples trayectorias que favorecen la resiliencia, así como la auto-superación y las emociones positivas, otros autores inciden en que se trata de un constructo muy similar y que la palabra hardiness ha ido perdiéndose en favor de la palabra resiliencia (Collins, 2008). En nuestra opinión, es importante mantener diferenciados los dos conceptos en cuanto a que hardiness está concebida más como un rasgo de personalidad relativamente estable, mientras que la resiliencia es más dinámica.

De acuerdo con Bonanno (2004), es asimismo importante distinguir el concepto de resiliencia del concepto de recuperación, ya que representan trayectorias distintas. La recuperación está caracterizada por una trayectoria que prevé una modificación temporal del funcionamiento normal del individuo debido al comienzo de una psicopatología, como por ejemplo la depresión o el trastorno de estrés post-traumático. 
Este estado puede ser más o menos prolongado en el tiempo y está caracterizado por un retorno gradual a la normalidad funcional. Por el contrario, la resiliencia refleja un proceso caracterizado por una trayectoria relativamente estable en las funciones vitales durante toda la evolución: las personas con mayor resiliencia pueden experimentar perturbaciones transitorias en su funcionamiento normal, pero en general muestran una trayectoria estable de funcionamiento saludable, así como la capacidad de probar experiencias y emociones positivas. Además, la perspectiva de la resiliencia incluye el desarrollo de nuevas capacidades y una mayor habilidad para crear nuevas oportunidades (Lengnick-Hall, Beck, \& Lengnick-Hall, 2011).

En sentido opuesto se encuentra la vulnerabilidad, la cual es definida como antónimo de la resiliencia. Algunos investigadores han sugerido que, a lo largo del mismo continuo, ese constructo podría ser el polo opuesto a la resiliencia (Fergusson, Beautrais, \& Horwood, 2003). Se entiende por vulnerabilidad el proceso que lleva al incremento de la probabilidad de un resultado negativo e inadecuado frente a situaciones de exposición al riesgo. El resultado de vulnerabilidad sería por tanto la disfunción persistente, es decir, el resultado opuesto al funcionamiento renovado y adaptado típico de la resiliencia.

Finalmente, en algunas ocasiones, puede haber una confusión entre la resiliencia y ajuste positivo, afrontamiento y autoeficacia. Cada uno de estos constructos está muy relacionado con la resiliencia pero es distinto, de manera que no pueden ser utilizados como sinónimos. Con ajuste positivo y afrontamiento, por ejemplo, se hace referencia a los resultados de la resiliencia. Aunque, investigaciones previas han mostrado que la resiliencia se basa en parte en la autoeficacia; de hecho, una persona resiliente es a menudo definida como una persona que tiene un opinión saludable de sí misma y se siente eficaz y decidida (Hunter \& Chandler, 1999). Algunos de los adjetivos habitualmente utilizados para describir la autoeficacia también se utilizan para describir la resiliencia: fuerte, maleable, resistente a pesar de los obstáculos, adaptable y determinado (e.g., Bandura, 1997).

En conclusión, queremos remarcar que los conceptos analizados en este apartado en ocasiones se han considerados equivalentes a la resiliencia, en otras son considerados elementos centrales de la misma y en otras como opuestos. Sin embargo, creemos que es básico tener clara la caracterización de cada uno de ellos, así como los elementos de distinción, de cara a realizar investigaciones sólidas y coherentes sobre resiliencia. 


\section{Marco teórico en el estudio de la resiliencia organizacional}

La investigación en el ámbito organizacional a menudo hace referencia a la resiliencia, sin embargo su estudio resulta fragmentado ya que no existe un marco teórico de referencia claro (Sutcliffe \& Vogus, 2003). No obstante, algunos enfoques de la teoría organizativa pueden ofrecer explicaciones y fundamentación teórica para una mejor comprensión de la resiliencia organizacional. Desde luego, contar con una teoría de referencia podría proporcionar información valiosa sobre cómo las organizaciones, así como las personas y los grupos que las componen, logran alcanzar resultados deseables en medio de la adversidad, la tensión y los obstáculos a la adaptación o desarrollo. En este apartado se señalan brevemente algunas teorías de referencia: la teoría de aprendizaje organizacional y la teoría ecológica.

\subsection{Teoría de aprendizaje organizacional}

Una de las teorías a través de la cual se puede estudiar el tema de la resiliencia organizacional es la teoría del aprendizaje organizacional (Argyris, 1993; Schein, 1993; Senge, 2006). Esta teoría pone el acento en la capacidad de aprendizaje como la fuente de supervivencia a largo plazo de las organizaciones; así la premisa básica en la que se basa esta perspectiva es que el aprendizaje es la única ventaja competitiva sostenible a largo plazo. Desde esta perspectiva teórica, el aprendizaje es "un mecanismo fundamental por el cual las organizaciones, como sistemas abiertos, interactúan con su entorno, procesan información, y se adaptan a las cambiantes condiciones externas e internas" (Kuchinke, 1995, p. 308).

Bajo esta visión, la capacidad de las organizaciones de promover cambios en respuesta a los desafíos del entorno donde éstas se desarrollan es la fuente de su perdurabilidad a largo plazo. Por lo tanto, la posibilidad o voluntad de aprender se vislumbra como la única forma de responder al mundo cambiante y el sello distintivo de las organizaciones del mañana (Appelbaum \& Gallagher, 2000; Yeo, 2002).

\subsection{Teoría ecológica}

En línea con las premisas de la teoría ecológica (Holling, 1996), es importante estudiar las organizaciones en el contexto en que están situadas, y de ese modo evaluar su interacción con el mismo. De acuerdo con esta teoría, las organizaciones se configuran como sistemas que poseen la flexibilidad para adaptarse a las circunstancias cambiantes y encontrar nuevos equilibrios durante y después de la crisis (Adger, 2000). Esto es debido a que, al igual que las personas, tampoco las organizaciones existen 
como entes aislados ya que interactúan con, y están influidas por, el contexto psicológico, social y ambiental (ecológico). Por lo tanto, el contexto puede contribuir a determinar diferentes factores de riesgo, pero también puede proporcionar protección para mejorar la probabilidad de resultados positivos (Greene, 2002). Por ejemplo, un contexto organizacional caracterizado por la recesión económica puede ser considerado un factor de riesgo, pero al mismo tiempo se puede contar con un clima de apoyo social entre los miembros de la organización que actúe como factor de protección promoviendo una mejor adaptación a la situación y, por lo tanto, incremente la posibilidad de enfrentarse a ella para obtener resultados positivos.

Como conclusión, cabe destacar que las teorías presentadas pueden ser utilizadas como anclaje teórico en el estudio de la resiliencia organizacional, cada una haciendo hincapié en sus propias cuestiones clave, es decir: el aprendizaje organizacional y la interacción con el contexto, respectivamente. Sin embargo, un mayor desarrollo teórico del concepto sería deseable y necesario (Sutcliffe \& Vogus, 2003).

\section{Antecedentes y consecuencias de la resiliencia en contexto organizacional}

El estudio de la resiliencia en el ámbito organizacional es relativamente reciente, por lo tanto no existe una extensa base de evidencia empírica que defina cuáles son los antecedentes y las consecuencias de la resiliencia en dicho contexto. Sin embargo, se han detectado algunas variables que han demostrado tener un efecto positivo sobre su desarrollo, delineándole también algunas consecuencias positivas tanto para el trabajador como para la organización de pertenencia. A continuación, se señalarán las variables más importantes relacionadas con la resiliencia.

\subsection{Antecedentes de tipo personal}

A continuación se presentarán los antecedentes de tipo personal de la resiliencia que se han considerado más relevantes para esta revisión, es decir: la autoeficacia, las emociones positivas y las estrategias de coping.

\subsubsection{Autoeficacia}

Bandura (1997) establece la relación entre resiliencia y autoeficacia exponiendo que las personas con un alto nivel de autoeficacia son más resilientes cuando se enfrentan a condiciones adversas. Las personas más autoeficaces mantienen elevadas creencias en sus capacidades para superar la adversidad. Esa relación es explicada por el autor a través de la auto-reflexión, según la cual, habitualmente, los éxitos llegan tras 
llevar a cabo esfuerzos renovados después de intentos fracasados. Por eso es de gran importancia la eficacia personal en el desarrollo de las resiliencia (Bandura, 1998).

De manera similar, a nivel de equipo, la percepción de eficacia colectiva afecta positivamente a los niveles de resiliencia del grupo frente a las adversidades (Bandura, 2000). De acuerdo con estas directrices, se han encontrado correlaciones significativas entre autoeficacia y resiliencia tanto a nivel individual (Luthans, Avolio, Avey \& Norman, 2007) como colectivo (West et al., 2009). Sin embargo, es necesario estudiar más en profundidad dicha relación para determinar con mayor exactitud su naturaleza, en cuanto a que los estudios correlacionados no nos dan indicaciones acerca de la causalidad y podría ser que haya una influencia recíproca entre las dos variables.

\subsubsection{Emociones positivas}

La teoría Broaden-and-Build de las emociones positivas (Fredrickson, 1998; 2001) propone que éstas son una forma de adaptación avanzada que funciona para crear recursos duraderos. A diferencia de las emociones negativas, que estrechan la atención y la cognición para hacer frente a una amenaza inmediata (Carver, 2003), las emociones positivas tienen el potencial para calmar el estado de excitación generado por las emociones negativas y ampliar la atención de la persona, así como su pensamiento y los repertorios conductuales. Resultados previos demuestran que las emociones positivas producen patrones de pensamiento que son especialmente inusuales, flexibles, creativos, abiertos a la información y eficientes (p. ej., Isen, 2000). A lo largo del tiempo, estos modos de pensar ampliados crean recursos físicos, intelectuales y sociales, tales como la resiliencia.

En línea con esos supuestos, estudios previos han demostrado que las personas más resilientes son aquellas que utilizan estrategias que provocan emociones positivas para regular las situaciones emocionales negativas. Por ejemplo, durante incrementos de los niveles de estrés, utilizan el humor, utilizan técnicas de relajación y tienen pensamientos optimistas (Tugade \& Fredrickson, 2004). Esta relación ha mostrado efectos positivos tanto a nivel psicológico -ya que las emociones positivas están relacionadas con mayores niveles de resiliencia, que a su vez favorece el crecimiento de los recursos personales, como por ejemplo, optimismo, bienestar subjetivo y tranquilidad tras la crisis (Fredrickson, Tugade, Waugh, \& Larkin, 2003)- como a nivel fisiológico, ya que las emociones positivas favorecen que las personas más resilientes obtengan una recuperación cardiovascular más rápida (Tugade \& Fredrickson, 2004). La relación entre emociones positivas y resiliencia ha sido replicada también a nivel 
grupal en los equipos de trabajo, mostrándose evidencias de que las emociones positivas colectivas tienen una influencia sobre la resiliencia grupal (ver capítulo 4 de la presente disertación).

La relación entre emociones positivas y resiliencia se confirma también en el tiempo generando espirales positivas ascendentes en las que las emociones positivas y la resiliencia se influyen y se generan la una a la otra (Cohn, Fredrickson, Brown, Mikels, \& Conway, 2009). Es decir, así como las emociones positivas conducen a niveles más altos de resiliencia, la resiliencia actúa también generando emociones positivas, de manera que, ante situaciones estresantes, las personas más resilientes generan y emplean las emociones positivas para hacerle frente.

\subsubsection{Estrategias de coping}

Diferentes estudios han resaltado la importancia de las estrategias de coping (es decir, de afrontamiento) a la hora de hacer frente a situaciones adversas y estresantes, y favoreciendo de esa forma el desarrollo de la resiliencia (p.ej., Clauss-Ehlers, 2008; Fletcher \& Sarkar, 2013; Leipold \& Greve, 2009). Aunque a menudo los dos términos se han usado de manera intercambiable, es importante matizar su diferenciación para entender por qué las estrategias de coping se pueden considerar antecedentes de la resiliencia. Mientras con el término coping se hace referencia a un conjunto de estrategias cognitivas y conductuales usadas por el individuo con el fin de manejar las demandas de una situación estresante (Folkman \& Moskowitz, 2004), con resiliencia se hace referencia a la adaptación exitosa frente a estas situaciones (Campbell-Sills, Cohan, \& Stein, 2006). Es decir, las estrategias de coping se pueden considerar un abanico de diferentes técnicas, diversas en cuanto a objetivos y orientación, cuya aplicación más o menos adecuada puede favorecer o no el desarrollo de la resiliencia. La investigación desarrollada hasta el momento, ha puesto en evidencia que la tradicional distinción entre estrategias de coping, enfocadas a la tarea y enfocadas a la regulación de las emociones negativas (Folkman \& Lazarus, 1980), se puede considerar un buen punto de salida para predecir el desarrollo de la resiliencia. La evidencia empírica nos dice que, mientras las estrategias de coping enfocadas a la tarea tienen una relación positiva con la resiliencia, la relación entre las estrategias de coping enfocadas a la regulación de las emociones negativas y la resiliencia es negativa (Campbell-Sills et al., 2006). Eso es, enfrentarse de manera activa y con un enfoque a la resolución de los problemas favorece la resiliencia, mientras que abstenerse o desvincularse de la resolución de los mismos es perjudicial. 
Más recientemente, la distinción tradicional entre estrategias de coping ha sido puesta en discusión debido a la evidencia empírica recogida a lo largo de años de investigación en este campo, a lo largo de los cuales se han identificado unas estrategias de coping enfocadas a la regulación de las emociones positivas (Folkman \& Moskowitz, 2004). Específicamente, se hace referencia a estrategias de tipo cognitivo que se utilizan para gestionar el significado de las situaciones y regular la experiencia de emociones positivas. De acuerdo a esta nueva propuesta, se ha examinado el rol de las estrategias de coping enfocadas a la regulación de las emociones positivas como antecedentes de la resiliencia, y los resultados indican que estas estrategias tienen una relación positiva con la misma (ver capítulo 5 de la presente disertación).

\subsection{Antecedentes relacionados con la organización}

A continuación se presentarán los antecedentes de la resiliencia relacionados con el contexto organizacional considerados más relevantes para esta revisión, es decir, las relaciones interpersonales, las demandas y los recursos laborales.

\subsubsection{Relaciones interpersonales}

Un creciente cuerpo de evidencia empírica apoya la idea de que las relaciones interpersonales positivas son un requisito importante para el desarrollo de la resiliencia, tanto a nivel individual como de equipo (Stephens et al., 2013). Por ejemplo, diferentes autores evidencian la importancia de mantener y mejorar las relaciones con y entre los empleados durante situaciones de crisis para asegurar el compromiso y productividad (p. ej., Gittell, Cameron, Lim, \& Rivas, 2006). Eso es debido a que las relaciones interpersonales pueden ayudar a desarrollar, acumular y facilitar el acceso a recursos importantes, reducir el impacto de las situaciones amenazantes y proveer información clarificadora que reduce la incertidumbre (Stephens et al., 2013). Por lo tanto, las organizaciones, así como las personas y los grupos que la componen, emplean las relaciones personales como fuente de fuerza en situaciones adversas (Kahn, 2005), pero también como medios para fortalecer sus capacidades (Sutcliffe \& Vogus, 2003).

Sin embargo, no todas las relaciones son igual de importantes para el desarrollo de la resiliencia. De hecho, las relaciones pueden tanto facilitar como entorpecer el compartir de informaciones, los procesos de aprendizaje y el desarrollo de soluciones adaptativas para los problemas que se presentan (p.ej., Paulus \& Nijstad, 2003). La investigación sugiere que las relaciones positivas y de alta calidad son las más 
importantes, ya que a través de éstas es más fácil comprender las situaciones adversas y tejer la mejor manera de enfrentarse a ellas (Carmeli, Friedman, \& Tishler, 2013).

\subsubsection{Demandas y recursos laborales}

De acuerdo con la reconocida taxonomía propuesta por el modelo demandasrecursos laborales (Demerouti, Bakker, Nachreiner, \& Schaufeli, 2001), las condiciones físicas, sociales y/u organizacionales del trabajo pueden ser clasificadas en dos macrocategorías: las demandas y los recursos laborales. En cuanto a las demandas, se definen como las condiciones que requieren un esfuerzo mantenido (físico, social $\mathrm{y} / \mathrm{u}$ organizacional) por parte de la persona y están asociadas a un coste físico y/o psicológico (mental o emocional). En cambio, los recursos se definen como las condiciones que favorecen la consecución de las metas en cuanto a que estimulan el crecimiento y el desarrollo personal y profesional (Bakker \& Demerouti, 2007).

Considerando las demandas y los recursos laborales como antecedentes de la resiliencia en los equipos de trabajo, se ha demostrado que hay una relación positiva entre los recursos laborales de tipo social (es decir, clima de apoyo social y coordinación) y la resiliencia grupal, mientras que no se aprecia un efecto directo de las demandas (sobrecarga cuantitativa, conflicto y ambigüedad de rol). Sin embargo, se ha determinado un efecto de moderación de las demandas en la relación entre recursos y resiliencia. Eso significa que el efecto de los recursos sobre la resiliencia se ve disminuido cuando los equipos se enfrentan a altas demandas laborales, es decir: a mayor cantidad de demandas laborales, más débil será la relación entre recursos y resiliencia (ver capítulo 3 de la presente disertación).

\subsection{Consecuencias personales y organizacionales}

En este apartado se presentarán las principales consecuencias de la resiliencia; a saber: el desempeño, las actitudes hacia el trabajo y la mejor reincorporación al mercado laboral.

\subsubsection{Desempeño}

Mientras algunos investigadores sugieren que la resiliencia favorece el retorno al nivel "normal" de funcionamiento después de enfrentarse a una situación estresante (Masten et al., 1999), otros indican que puede haber un incremento en el desempeño debido al desarrollo de la resiliencia (Luthar, 1991). Ambas perspectivas teóricas están avaladas por un número todavía limitado de estudios empíricos, en los que se ha puesto en evidencia que en algunos casos la resiliencia está positivamente relacionada con un 
mejor desempeño laboral (p. ej., Luthans, Avolio, Walumbwa, \& Li, 2005), mientras que en otros esta relación no es significativa (p. ej., Youssef \& Luthans, 2007). Incluso a lo largo de la presente disertación, se han obtenido resultados divergentes: mientras que se ha hallado una relación positiva directa entre la resiliencia de los equipos de trabajo y el desempeño grupal (ver capítulos 3 y 4), esta relación no se ha encontrado a nivel individual (ver capítulos 5 y 6).

Aunque es importante tener en consideración que la resiliencia fomenta estrategias de afrontamiento tanto reactivas como proactivas de cara a situaciones complejas y amenazantes (Longstaff, 2005), lo que favorece un esfuerzo extra que se puede traducir en un incremento del desempeño, consideramos que más investigación es necesaria para determinar con más precisión si la influencia de la resiliencia sobre el desempeño es directa o está mediada por alguna otra variable.

\subsubsection{Actitudes hacia el trabajo}

El estudio de Youssef y Luthans (2007) muestra evidencia de que la resiliencia de los empleados tiene un impacto positivo en la satisfacción, el compromiso y la felicidad en el trabajo. La relación entre resiliencia y satisfacción se replica en ámbito laboral y académico a lo largo de la presente disertación (ver capítulos 5 y 6) y estos resultados son coherentes con los supuestos de la resiliencia, ya que se considera una variable importante a la hora de percibir y determinar interpretaciones positivas de factores de riesgo que, de otra manera, serían interpretadas sólo como amenazas (Masten, 2001). Resultados muy interesantes se hallaron a través del estudio de Liossis, Shochet, Millear y Biggs (2009), en el cual se demostró que desarrollando la resiliencia en personas adultas por medio de programas formativos específicos se producen consecuencias positivas relacionadas con el bienestar de la persona, tanto a nivel personal como laboral. En el ámbito laboral, encontraron que los participantes, en comparación con el grupo control, mostraron un incremento de las creencias de eficacia acerca de las estrategias de afrontamiento en el trabajo, de la satisfacción en la conciliación familiatrabajo, del ajuste entre demandas laborales y familiares, así como un incremento de optimismo, satisfacción y vigor en el trabajo. Además, las personas señalaron niveles inferiores de estrés y menor agotamiento. En conjunto, las personas que participaron en este programa se sentían más seguras y optimistas acerca de sus habilidades, tenían más energía, sentían mayor satisfacción por el trabajo y experimentaban menos conflictos entre familia y trabajo, tanto al finalizarlo como transcurridos cinco meses. 


\subsubsection{Reincorporación al mercado laboral}

Investigaciones recientes revelan que hoy en día las empresas pueden ofrecer cada vez menos estabilidad laboral para sus empleados (Brown, 2005), situación que en algunos países se encuentra agravada por la actual crisis económica y la alta tasa de desempleo alcanzada. Con el fin de favorecer la reincorporación de las personas desempleadas al mercado laboral, estudios novedosos proponen que la resiliencia actúa como variable clave, ya que ofrece explicaciones acerca del porqué las personas que están buscando trabajo son capaces de superar los rechazos para seguir con su búsqueda hasta el momento de reincorporarse al mercado laboral (Fleig-Palmer et al., 2009). Por lo tanto, un enfoque práctico para favorecer la reincorporación al mercado laboral de las personas desempleadas debe hacer hincapié en el rol de la resiliencia, ya que se configura como un proceso clave para enfrentarse a las adversidades relativas al desempleo y para favorecer la búsqueda de nuevas experiencias, retos y oportunidades (Reivich \& Schatte, 2002).

\section{Antecedentes y consecuencias de la resiliencia organizacional}

En el estudio de la resiliencia organizacional se han propuesto diferentes antecedentes, o conjuntos de los mismos, que contribuyen a su desarrollo. Es decir, en condiciones adversas, la resiliencia organizacional se desarrolla siempre y cuando estén presentes unos recursos latentes (los antecedentes) que pueden ser activados, combinados y reorganizados (Vogus \& Sutcliffe, 2007). Seguidamente se detallan tres propuestas diferentes desarrolladas en la literatura, así como sus consecuencias para las organizaciones. Finalmente, se presentará un modelo integrador más reciente que considera antecedentes y consecuencias en las organizaciones resilientes.

\subsection{Antecedentes}

\subsubsection{Propuesta de Horne y Orr}

Horne y Orr (1998) sugieren que hay siete directrices o pautas dentro de una organización que, empleadas en un enfoque general de sistemas, contribuyen a la resiliencia organizacional: comunidad, competencia, conexiones, compromiso, comunicación, coordinación y consideración. Comunidad se refiere a la comprensión por parte de los empleados de la finalidad, la visión, la misión y los valores de la organización. La competencia hace referencia a las habilidades de los empleados para satisfacer las demandas de los entornos cambiantes. Conexiones se dirige al apoyo social dentro de la organización, que permite a las organizaciones responder bajo 
presión. El compromiso es la capacidad de todas las unidades de la organización para trabajar en equipo durante los períodos de cambio. La comunicación se centra en el intercambio de información relevante durante los períodos de cambio. Coordinación se refiere a los esfuerzos para adaptar todo el sistema con el fin de lograr resultados eficaces. Por último, la consideración se refiere a la adaptación y acomodación del factor humano en la vida de la organización diaria.

Los autores recomiendan que estas pautas deban ser evaluadas a nivel general, ya que conjuntamente ayudan a la organización a cumplir sus objetivos en tiempos de crisis. Esto es, se debe emplear un enfoque general de sistemas para entender cómo se desarrolla la resiliencia a nivel organizacional. Eso porque, a nivel organizacional, tales pautas conducen a resultados favorables a través de la facilitación del procesamiento de la información en condiciones de estrés. En lugar de desorientarse y ofuscarse por situaciones agudas o crónicas de estrés, las organizaciones que cuentan con las siete pautas señaladas anteriormente son capaces de absorber y transformar las condiciones estresantes en beneficio de la organización en su conjunto.

\subsubsection{Propuesta de Gittel, Cameron, Lim y Rivas}

En un estudio efectuado en las diez compañías aéreas americanas más importantes después de los ataques del 11 de septiembre de 2001, los autores identifican cuatro condiciones imprescindibles para lograr resultados positivos después de una situación adversa (Gittell et al., 2006). La primera es que se mantengan y mejoren las relaciones interpersonales con los empleados, para de esa forma, asegurar su compromiso organizacional y productividad. También se resalta la importancia tanto de contar con un modelo de negocio apropiado para el contexto como de tener buenos recursos financieros, medidos a través del flujo de caja y de los bajos niveles de deuda. Finalmente, los autores destacan la importancia de una estrategia enfocada a evitar los despidos, debido a sus efectos nefastos sobre la rentabilidad, la calidad del producto y del servicio, la innovación y el clima organizacional (Cameron, 1998). Además, la violación del contrato psicológico originada por la reducción de la plantilla (Rousseau, 1995) es causa de desconfianza y antagonismo entre los trabajadores, de manera que los despidos provocan muchas veces un deterioro en las relaciones interpersonales.

Es decir, las organizaciones se enfrentan de manera más eficaz a las crisis cuando evitan los despidos, mantienen fuertes relaciones interpersonales, cuentan con suficientes recursos financieros y cuando disponen de un modelo de negocio que se adecua a las necesidades de su entorno competitivo. Además, dichos recursos tienden a 
reforzarse mutuamente entre sí, de manera que establecen espirales virtuosas que contribuyen al desarrollo de la resiliencia organizacional.

\subsubsection{Propuesta de Carthey, De Leval y Reason}

En la acepción de Carthey, De Leval y Reason (2001), los conceptos de resiliencia y vulnerabilidad pueden ser representados como los extremos de un hipotético espacio, llamado espacio de seguridad. Los extremos del eje horizontal de este espacio se identifican con la máxima resiliencia y con la máxima vulnerabilidad. Dependiendo de la manera más o menos eficaz de enfrentarse a los riesgos humanos y técnicos asociados con su actividad diaria, las organizaciones suelen estar posicionadas y moverse a lo largo de este espacio de resiliencia-vulnerabilidad.

Los autores indican que el objetivo más realista para las empresas no es el de distanciarse del polo de vulnerabilidad por sufrir cero eventos adversos, sino más bien hacer frente a dichos eventos y alcanzar el máximo nivel de resiliencia posible. Para conseguirlo, las organizaciones se deben guiar a lo largo de este espacio a través de tres precursores intrínsecos de la cultura organizacional: compromiso, competencia y conocimiento. El compromiso cuenta con dos componentes: motivación y recursos, sean monetarios o prácticas percibidas por parte de la organización. La competencia hace referencia a las habilidades para identificar los riesgos, las diferentes estrategias de protección, y para establecer una estructura organizacional suficientemente flexible y adaptativa. Finalmente, con conocimiento se hace referencia a cómo la organización atribuye sentido a los riesgos y peligros, manteniendo un estado de inteligente cautela aun en ausencia de resultados negativos. Asimismo, las organizaciones pueden contar con dos tipos de ayuda para moverse hacia la resiliencia. Por un lado, con medidas de tipo reactivo, es decir, derivadas de la recopilación y análisis de los incidentes críticos con la finalidad de descubrir modelos recurrentes de causas y efectos. Por otro lado, con medidas proactivas centradas en identificar y determinar con anticipación aquellos factores o situaciones que pueden contribuir a accidentes futuros y necesitan corrección.

\subsection{Consecuencias}

En líneas generales, se considera que la resiliencia permite a las organizaciones, así como a las personas y grupos que las componen, enfrentarse de manera positiva a las situaciones adversas (Sutcliffe \& Vogus, 2003). Sin embargo, no existe acuerdo en la investigación para definir cuáles son los resultados y/o consecuencias de la resiliencia para la organización (Lengnick-Hall et al., 2011; Somers, 2009). 
Para algunos autores, que consideran la resiliencia organizacional en términos más pasivos, ésta se caracteriza por enfrentarse a las situaciones adversas y volver a los resultados esperados antes de dicha situación, para lograr así la supervivencia de la organización. La consecuencia principal es que la organización restablece un equilibrio con la nueva realidad y sigue manteniendo sus resultados (p. ej., Gittell et al., 2006; Sutcliffe \& Vogus, 2003). En cambio, para otros autores, la resiliencia organizacional va más allá de la recuperación y, por haber aprovechado las situaciones como oportunidades, incluye el desarrollo de nuevas habilidades y capacidades para responder a los cambios y lograr oportunidades más rápido que sus competidores, así como el logro de resultados más positivos. De acuerdo con esta perspectiva, las organizaciones más resilientes serán las que mejoren su rendimiento y prosperen después de enfrentarse a las situaciones adversas (p. ej., Lengnick-Hall \& Beck, 2003; Longstaff, 2005).

\subsection{Una propuesta de integración: el modelo HERO}

El modelo HERO - HEalthy and Resilient Organizations (Salanova et al., 2012) se propone como un modelo heurístico integrado que describe el funcionamiento de las organizaciones saludables y resilientes. Las autoras definen las HERO como organizaciones que hacen esfuerzos sistemáticos, planificados y proactivos para mejorar los procesos y los resultados de sus empleados, equipos y de la organización misma. Además, dichas organizaciones son resilientes porque mantienen un ajuste positivo en condiciones desafiantes, se recuperan de las situaciones adversas y conservan un nivel de funcionamiento $\mathrm{y}$ de buenos resultados a pesar de encontrarse en entornos estresantes.

El modelo HERO está determinado por tres elementos clave que, desarrollándose de forma sistemática e interactiva, determinan el éxito saludable y resiliente de la organización: (1) recursos y prácticas organizacionales para estructurar y gestionar los procesos de trabajo (p. ej., autonomía, etc.) que influirían en el desarrollo de (2) empleados/equipos saludables que muestran elevados niveles de bienestar (p. ej., resiliencia, etc.) y que en conjunto generarán (3) resultados organizacionales saludables (p. ej., desempeño in- y extra- rol, etc.). Una organización resiliente tiene como objetivo que sus productos y sus servicios sean de excelencia, y que sean óptimas las relaciones de la organización con el ambiente extra-organizacional, la comunidad cercana y la sociedad en general. El modelo se muestra gráficamente en la figura 2.1. Es importante resaltar que la relación entre dichos elementos influye en los procesos de trabajo en la 
dirección de mejora constante en el tiempo (Salanova et al., 2012). De acuerdo con este modelo, la resiliencia cobra importancia a todos los niveles de la organización: individual y grupal, como característica que determina empleados y equipos resilientes, así como organizacional, ya que el objetivo de este modelo es el de precisar las características y las consecuencias de una organización que es resiliente en contextos adversos.

Figura 2.1. Modelo HERO

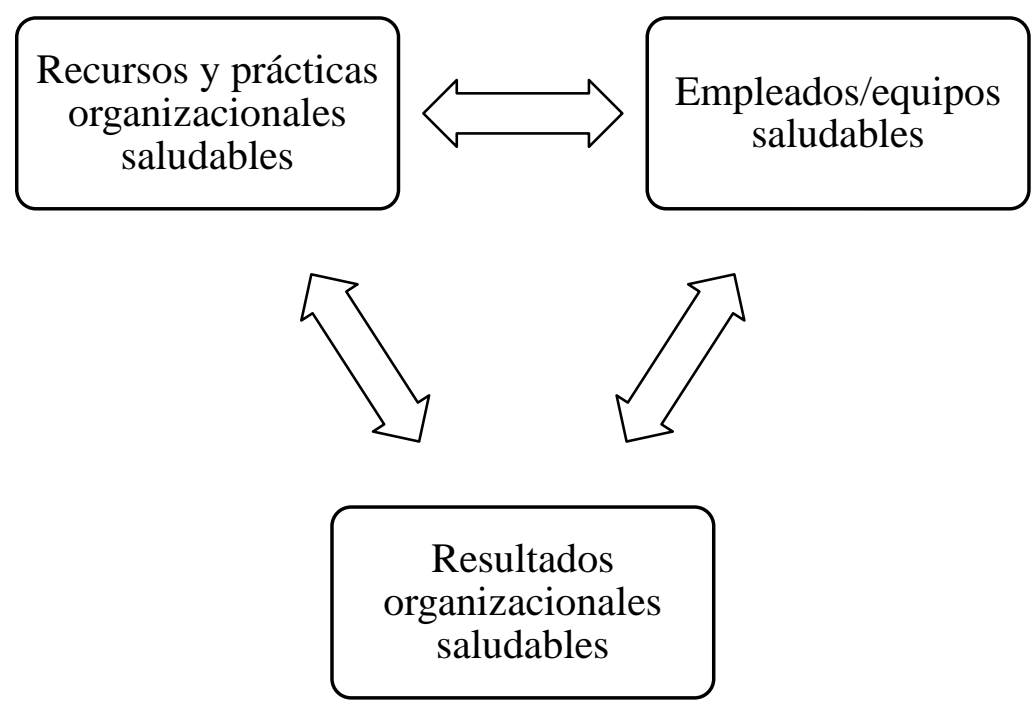

\section{Evaluación de la Resiliencia}

Las herramientas de evaluación más utilizadas para medir la resiliencia son indudablemente los cuestionarios de auto-informe y son, por ende, donde existen más propuestas. Por tanto, la presente revisión teórica se centra únicamente en ese tipo de herramienta, específicamente en los cuestionarios de auto-informe que más investigación han generado y que permiten evaluar la resiliencia con suficientes garantías de calidad. Sin embargo, existen otras herramientas de evaluación como el check-list (ej., Checklist for assessing institutional resilience, CAIR; Carthey et al., 2001).

\subsection{RS: Resilience Scale}

Confeccionado por Wagnild y Young en 1993 a raíz de los resultados de un estudio cualitativo, este cuestionario mide la resiliencia a través de 25 ítems y una escala de respuesta tipo Likert de 7 puntos que oscila entre 1 (en desacuerdo) y 7 (de acuerdo). Diferencia dos dimensiones de la resiliencia: competencia personal y 
aceptación de uno mismo y de la vida. Todos los ítems están redactados de forma positiva, por lo tanto las puntuaciones más altas reflejan mayor resiliencia, y se han desarrollado a partir de las declaraciones de los participantes en el estudio original cualitativo, que incluye a 24 mujeres que habían logrado adaptarse con éxito a situaciones muy adversas (Wagnild \& Young, 1990). La escala ha sido validada con 810 sujetos y el alpha de la escala es .91. La dimensión de competencia personal se evalúa con ítems como: "Puedo superar momentos difíciles debido a la experiencia", mientras que la dimensión de aceptación de uno mismo y de la vida se evalúa con ítems como: "Normalmente me tomo las cosas con calma".

Estudios más recientes centrados en el ámbito laboral han utilizado y adaptado 6 ítems del RS para medir la resiliencia individual en el Psychological Capital Questionnaire, o PCQ (Luthans, Youssef, \& Avolio, 2007). Un ejemplo de ítem es: "Por lo general me tomo con calma las cosas estresantes en el trabajo". Esta última escala también ha sido adaptada a nivel colectivo para los equipos de trabajo por West y colaboradores (2009). Un ejemplo de ítem es: "En nuestro equipo se suelen gestionar las dificultades del trabajo de una manera u otra".

\subsection{CD-RISC: Connor Davidson Resilience Scale}

Este instrumento fue creado por Connor y Davidson en 2003 y se compone de 25 ítems distribuidos en 5 dimensiones: competencia personal, confianza en la intuición y tolerancia a la adversidad, aceptación del cambio, control e influencias espirituales. Tiene una escala de respuesta tipo Likert de 5 puntos que oscilan entre 0 (nada de acuerdo) y 4 (muy de acuerdo). La puntuación máxima es de 100 puntos: cuanto mayor sea la puntuación mayor será el nivel de resiliencia. La escala ha sido validada con 806 sujetos y el alpha de la escala es .89. La primera dimensión refleja la noción de competencia personal, altos estándares y tenacidad con ítems como: “Incluso cuando las cosas parecen sin esperanza, no me doy por vencido". La segunda dimensión corresponde a confiar en los instintos, la tolerancia a los sentimientos negativos y el fortalecimiento de los efectos del estrés y se mide con ítems como: "Puedo manejar los sentimientos desagradables". La dimensión 3 se refiere a la aceptación positiva del cambio y relaciones seguras con ítems como: "Puedo hacer frente a lo que venga". La cuarta dimensión se relacionó con el control, con ítems como: "Tengo control sobre mi vida". La ultima dimensión se refiere a las influencias espirituales con ítems como: "Las cosas pasan por una razón". 


\subsection{BRS: Brief Resilience Scale}

El cuestionario ha sido confeccionado por Smith y colaboradores (2008) y cuenta con 6 ítems y una sola dimensión que evalúa la capacidad de rebotar o recuperarse del estrés. Los autores señalan que la mayoría de las medidas de resiliencia, en lugar de evaluar específicamente la resiliencia como el proceso de resistencia, de recuperación y adaptación al estrés, se han centrado en el examen de los recursos o factores de protección que podrían facilitar la resiliencia. Por tanto, las medidas anteriores de resiliencia parecían proporcionar una puntuación resumen de los recursos que apoyan la resiliencia. En cambio, esta breve escala fue desarrollada con el objetivo de diseñar una medida de resultado para evaluar la capacidad de rebotar o recuperarse del estrés.

Incluye el mismo número de ítems redactados en positivos y negativos para reducir los efectos de la deseabilidad social y el sesgo de respuesta positiva. La escala de respuesta es tipo Likert con 5 puntos de anclaje que oscilan entre 1 (nada de acuerdo) y 5 (muy de acuerdo). La escala ha sido validada en cuatro muestras diferentes, y el alpha de la escala oscila entre .80 y .91. Un ejemplo de ítem es: "Tiendo a recuperarme rápidamente después de momentos difíciles".

\subsection{Cuestionario HERO de resiliencia grupal}

Este instrumento ha sido elaborado y validado por Salanova y colaboradoras en 2012 para medir la resiliencia grupal en ámbito laboral. Cuenta con 7 ítems inspirados en los principios de resiliencia organizacional propuestos por Mallak (1998) y cuyo referente es el equipo de trabajo. Es decir, los ítems hacen referencia a la percepción individual acerca de la resiliencia del propio equipo. La escala de respuesta es de tipo Likert con 7 puntos de anclaje que oscilan entre 0 (nunca) y 6 (siempre). Un ejemplo de ítem dirigido a los empleados para que puntúen sobre la resiliencia del equipo en el que trabajan es: "Ante situaciones de incertidumbre y crisis, nos adaptamos a los cambios que van surgiendo de forma positiva, y además nos hacemos más "fuertes" cuando los superamos". La escala ha sido validada con 710 empleados de diferentes empresas y sectores económicos, siendo el alpha de la escala .83.

En este apartado se han presentado los cuatro instrumentos para la medición de la resiliencia considerados más relevantes por parte de los autores, ya sea porque son los que tradicionalmente han generado más investigación (i.e., RS y CD-RISC), ya sea por el enfoque más centrado en medir la resiliencia como capacidad de rebotar o recuperarse del estrés (i.e., BRS) mientras que los dos anteriores se enfocan más en los 
recursos de la resiliencia, o finalmente por el enfoque novedoso y actual en los equipos de trabajo (i.e., cuestionario HERO de resiliencia grupal).

\section{Conclusiones}

Aunque ya se han realizado algunos esfuerzos en la investigación sobre resiliencia en la psicología del trabajo y de las organizaciones, desde el desarrollo del concepto hasta ahora nuevos modelos conceptuales e investigaciones siguen animando este campo. Como resultado de esta revisión, queremos resaltar que la resiliencia en el contexto laboral es un concepto complejo sobre el cual, sobre todo en épocas de crisis como la actual, se reflexiona y debate mucho; sin embargo, quedan todavía muchos aspectos por estudiar. La falta de consenso sobre algunas características que la definen, así como la confusión que genera el no distinguirla de otros conceptos similares como la ego-resiliency o la recuperación, son cuestiones que hay que tener presentes para avanzar en el estudio de la resiliencia.

El creciente interés en la resiliencia a nivel individual y colectivo en el contexto laboral está contribuyendo a clarificar cuáles son los antecedentes para el desarrollo de la misma, así como cuáles son los resultados o consecuencias más relevantes de este proceso en los empleados y grupos que conforman las organizaciones. Como se ha delineado a lo largo de esta revisión, los antecedentes de la resiliencia en el contexto laboral más investigados hasta el momento son de tipo personal, como por ejemplo las emociones positivas o la autoeficacia. Se han realizado también algunos esfuerzos para estudiar los antecedentes relacionados con la organización y/o las características del trabajo, por ejemplo investigando el rol de algunas demandas y de algunos recursos laborales; sin embargo, la investigación es todavía escasa y a nuestro parecer insuficiente. Se necesita por tanto una mayor investigación para determinar con mayor precisión qué características de la organización y del trabajo influyen en el desarrollo de la resiliencia de trabajadores y equipos de trabajo. En cuanto a las consecuencias de la resiliencia, se aprecia un mayor énfasis en su estudio, y se han determinado resultados relevantes tanto para los empleados y los grupos así como para la misma organización. Por ejemplo, consecuencias tales como son el desempeño y las actitudes laborales tienen un efecto positivo para la organización, pero también son medidas del bienestar de los trabajadores.

Además, tal como se ha resaltado, las investigaciones se han dirigido también al estudio directo de la resiliencia organizacional para avanzar en nuestro conocimiento 
acerca del porqué hay algunas organizaciones que sucumben ante situaciones adversas, mientras que hay otras que las superan y se hacen todavía más fuertes. Sin embargo, un estudio más sistemático de antecedentes y consecuencias de la resiliencia organizacional quedan como asignaturas pendientes y se convierten en un reto futuro para delinear estrategias de desarrollo en las organizaciones, así como en los empleados y grupos que las conforman. Como se ha evidenciado a lo largo de esta revisión, cada modelo propone sus propios determinantes clave para el desarrollo de la resiliencia organizacional, y en raras ocasiones hay coincidencia entre los mismos a través de diferentes modelos. Los avances en esa dirección se configuran como fundamentales también para establecer con claridad el valor añadido de la resiliencia en las organizaciones, hasta el momento argumentado más a nivel conceptual y teórico que con evidencias empíricas. En este sentido, un adelanto se ha realizado a través del desarrollo del modelo HERO, ya que propone un sistema integrado de antecedentes y consecuencias laborales que caracterizan a las organizaciones saludables y resilientes.

Por lo que respecta a las herramientas de evaluación de la resiliencia, actualmente se dispone de diferentes instrumentos destinados a evaluar la resiliencia en general; sin embargo, muy pocos son específicos para el contexto laboral. Además, tampoco hemos podido encontrar una herramienta de evaluación específica para la Resiliencia a nivel organizacional. El último de los cuestionarios descritos -el de HERO- parece prometedor en cuanto a que está enfocado al contexto organizacional y más específicamente a los equipos de trabajo que lo conforman. Sin embargo, se necesita más investigación para confirmar sus propiedades psicométricas, ya que es un instrumento bastante reciente.

Como conclusión, en el presente trabajo se ha realizado una revisión teórica del concepto de resiliencia en el contexto organizacional, con el objetivo de examinar los estudios empíricos que se han llevado a cabo en los últimos años para determinar el statu quo del constructo. A pesar de los estudios realizados hasta la fecha, queda todavía mucho camino por recorrer en el estudio y la comprensión de qué variables determinan que una organización, así como los empleados y los equipos que la componen, sean capaces de enfrentarse a situaciones adversas y lograr una adaptación exitosa para salir más fuertes y resistentes. En el siguiente y último apartado de este trabajo, se sugieren unas futuras líneas de investigación y preguntas que quedan por resolver. 


\subsection{Retos para la investigación futura}

A partir del análisis realizado y lo expuesto anteriormente, es indudable que unos resultados más sistemáticos y específicos sobre el estudio de la resiliencia en el contexto laboral permitirían establecer con más claridad cuáles son los factores que están relacionados con el desarrollo de la resiliencia de empleados, grupos y organizaciones. De esta manera, consideramos que hay unos aspectos más destacables y que necesitan mayor desarrollo en la investigación. Para ello, a continuación se detallan algunos retos futuros:

Reto 1. Es evidente la necesidad de confirmación empírica de los supuestos modelos de resiliencia organizacional, con el objetivo de establecer cuáles son los determinantes y las consecuencias de la resiliencia. ¿Es posible crear un modelo integrador que determine qué variables favorecen el desarrollo de la resiliencia en la organización? ¿Cuáles son los efectos o las consecuencias de la resiliencia sobre resultados organizacionales objetivos y observables, tales como, por ejemplo, la productividad, el absentismo y los indicadores económicos-financieros?

Reto 2. Se ha evidenciado la importancia de algunos determinantes de tipo personal en el desarrollo de la resiliencia en el contexto laboral, a nivel tanto individual como colectivo. Esos determinantes, ¿serían siempre los mismos en los dos niveles de análisis? ¿Podemos decir que hay unos mismos antecedentes que favorecen tanto la resiliencia individual como la resiliencia colectiva? Y también, ¿hay unos antecedentes de tipo personal específicos que influyen solo a nivel individual o solo a nivel colectivo?

Reto 3. Queda mucho trabajo para distinguir determinantes de tipo laboral $\mathrm{u}$ organizacional que influyen en el desarrollo de la resiliencia individual y colectiva. Por ejemplo, ¿hay algunas prácticas organizacionales que favorecen el desarrollo de la resiliencia? Más allá de las relaciones interpersonales, ¿influyen también recursos de tarea o estructurales?

Reto 4. Un enfoque multinivel que tome en consideración simultáneamente los diferentes niveles de la resiliencia en las organizaciones (es decir: individual, colectiva y organizacional) sería indispensable para establecer si existen relaciones entre los mismos, así como posibles efectos y relaciones trasnivel. Por ejemplo, ¿la resiliencia organizacional incrementa la resiliencia de los equipos y de los empleados que componen la organización? Y al revés, ¿la resiliencia de los empleados y de los equipos es importante para fomentar la resiliencia de la organización? 
Reto 5. Conjuntamente, a través de estudios de diseño longitudinal, sería interesante examinar los cambios en el tiempo en la relación entre resiliencia y las variables con ella relacionadas, sean antecedentes o consecuencias. A excepción de algunos resultados puntuales, carecemos de datos acerca de una posible retroalimentación entre la resiliencia y las variables a ella relacionadas. Por ejemplo, ¿hay retroalimentación entre la resiliencia y los resultados positivos (es decir, el desempeño, el compromiso), de tal forma que la resiliencia favorezca los resultados positivos y éstos, a su vez, el desarrollo de la resiliencia? 


\title{
CHAPTER 3
}

\section{Job-Related Antecedents of Team Resilience and Improved Team Performance ${ }^{2}$}

\begin{abstract}
The purpose of this study is to investigate the potential role of team resilience as the psychological mechanism that explains how job demands and job social resources are related to and enhance team performance. Self-reported questionnaires were distributed to 1633 employees, nested in 275 teams from 52 Spanish SMEs. Aggregated scores were employed for a team-level SEM analysis. Results support a partial mediation model in which job social resources affect team resilience, and in turn impact team performance. No significant effects were found for job demands affecting team resilience. However, the demands $\times$ resources interaction influences team resilience, and thus the impact of resources on team resilience was attenuated by demands. In the same way, the demands $\times$ resources interaction influences team performance. Thus, job social resources are related to team performance, but team resilience is a significant mediator. Further research should investigate the effects of different job demands on team resilience. In terms of practical implications, the results suggest that managers should focus on developing job social resources to augment team resilience and team performance. They also could benefit from understanding how team resilience could be developed, given that team resilience aids to achieve positive team outcomes.
\end{abstract}

Key words: Resilience, Team Resilience, Team Performance, Job Social Resources, Job Demands, Structural Equation Modeling

${ }^{2}$ Chapter 3 has been submitted for publication as: Meneghel, I., Martínez, I. M., \& Salanova, M. Job-Related Antecedents of Team Resilience and Improved Team Performance. Personnel Review. 


\section{Introduction}

The current organizational environment is frequently described as more unstable, complicated, and threatening than it has been in the past. Organizations, as well as the individuals and the teams that they are composed of, often have to face complex environments characterized by hyper-competition and rapid changes (Stephens, Heaphy, Carmeli, Spreitzer, \& Dutton, 2013; Sutcliffe \& Vogus, 2003). As a result, companies have often to shift their focus, and form and develop strategies to temporarily shut down, decrease production, or reduce costs (Avey, Luthans, \& Jensen, 2009), especially in situations like the current financial crisis. Thus, for organizations as well as their teams and members, it has become increasingly more important to develop the ability to effectively respond and promote positive adaptation to changes. Now then, why do some organizations survive by adapting while others fail? Recent calls have been addressed regarding the need to explore the potential role of variables that may have an impact on organizational performance in crisis scenarios, especially referring to resilience (Kaplan, Laport, \& Waller, 2012; Linnenluecke \& Griffiths, 2010). In fact, the resilience approach recognizes this need for flexibility, adaptation, and improvisation in situations characterized by change and uncertainty, as well as the need to find inner strengths and resources in order to cope effectively (Ganor \& Ben-Lavy, 2003; Youssef \& Luthans, 2007).

In the same way organizations are focusing increasingly more on the performance of their teams (Gully, Incalcaterra, Joshi, \& Beaubien, 2002), attention will be directed toward identifying the characteristics and processes that elicit the synergistic benefits assumed by team-based work structures (West, Patera, \& Carsten, 2009). However, despite teams' relevance in the lives of organizations, little research has been conducted on team-level resilience. If resilience matters for performance, what helps teams in organizations be and become resilient? Given that resilience development is also characterized by contexts of significant adversity (Masten \& Reed, 2002), a natural starting point for research is to establish criteria for ascertaining the presence of conditions that pose a threat (Sutcliffe \& Vogus, 2003). In addition, research suggests that resilience is facilitated by the existence and quality of interpersonal relationships (e.g., Gittel, Cameron, Lim, \& Rivas, 2006; Riolli \& Savicki, 2003). For example, the interactive, relational processes among team members can facilitate (or hinder) the 
sharing of information, learning processes, and the development of adaptive solutions to problems (Stephens et al., 2013).

To test the link between adverse conditions and resilience, as well as between interpersonal relationships and resilience, and how they affect team performance, we used the Job Demands-Resource (JD-R) model (Demerouti, Bakker, Nachreiner, \& Schaufeli, 2001) as a guiding framework. We suggest that job demands (i.e., quantitative overload, role conflict, and ambiguity) are linked to resilience since, to a certain extent, they represent adverse conditions in the organizational setting. In this case, because the sample held different jobs, we examine three kinds of demands that are present across various jobs and organizations (Gruman \& Saks, 2011). Furthermore, we focus on two kinds of job social resources (i.e., social support climate and team coordination) because research suggests that high-quality relationships are particularly valuable for resilience, since individuals and the teams they comprise are better able to collectively comprehend difficult situations and figure out the best way to deal with them (Carmeli, Friedman, \& Tishler, 2013). Thus, the proposed process that leads to positive team performance is as follows: the joining of high job social resources and high job demands leads to teams' resilience, which in turn relates to better team performance.

The present study extends previous research in several ways. First, given that teams comprised in organizations necessarily face setbacks and challenges in pursuing positive outcomes, we argue that positive outcomes are facilitated when teams develop resilience. Second, although earlier studies have examined mainly psychological predictors of resilience (i.e., positive emotions, see Algoe \& Fredrickson, 2011), we also included job antecedents - specifically, demands and resources - as potential antecedents. Finally, we proposed team resilience as a significant psychological mechanism to link job demands and resources on the one hand, and team performance on the other. Our results are aimed to suggest relevant guidelines for managers and HRM professionals to achieve positive team performance under adverse situations, like the current crisis scenario.

\section{Defining Team Resilience}

In the domain of organizations and management, the concept of resilience has been used by researchers and practitioners to refer to relatively ordinary adaptive processes when encountering unexpected, adverse conditions that result either from 
large-scale disturbances or the accumulation of several minor disruptions (Sutcliffe \& Vogus, 2003). Resilience may be considered as much an individual characteristic as a social factor in teams or organizations. Evidence shows that, in a similar way to individuals acting alone, individuals performing as teams tend to display somewhat regular patterns of behavior and processes (Stewart, 2010). Consistent with social identity theory (Tajfel \& Turner, 1985), individuals identify with their team and internalize its values and norms, which lead to homogeneity in attitudes and behavior. In our study we focus on team resilience, defined as "the capacity to bounce back from failure, setbacks, conflicts, or any other threat to wellbeing that they may experience" (West et al., 2009, p. 253). It should be highlighted that team resilience differs from other similar constructs like team potency and team efficacy because these constructs may be considered antecedents or evocative of team resilience, because "the sense of confidence generated by high levels of efficacy and potency is believed to help teams persevere in the face of adversity" (Gully et al., 2002, p. 819).

\section{Theoretical model and hypotheses}

The first aim of this study is to determine how team resilience is related to team performance, measured as in-role and extra-role performance, or task and contextual performance, respectively (Goodman \& Svyantek, 1999). We assumed that team resilience has a positive relationship with team performance because, in the same manner as individuals, highly resilient teams are likely to be creative, adaptive to change, and persistent in dealing with adversity (Luthans, Avolio, Walumbwa, \& Li., 2005), and additionally they tend to use setbacks as "springboards" or opportunities for growth (Tugade \& Fredrickson, 2004). For these reasons, they improved their work performance. Hence, we expect:

Hypothesis 1: Team resilience is positively associated with team performance.

The second aim of this study is to examine which work characteristics assist to develop resilience and, consequently, enhance their performance. According to the JD$\mathrm{R}$ model, the variety of psychosocial work characteristics can be classified into two broad groups, job demands and job resources, which incorporate different specific demands and resources depending on the context under study (detailed information can be found in Bakker \& Demerouti, 2007; Demerouti et al., 2001). As pointed out in the JD-R model, the presence of job resources stimulates personal growth and development, thus facilitating the accomplishment of work goals. This could be explained following 
the Conservation of Resources (COR) Theory (Hobfoll, 1989, 2002, 2011), which suggests that employees and groups are motivated to obtain, retain, and protect resources. A central assumption in COR theory is that people use their resources to deal with stressful conditions and protect themselves from negative outcomes. Accordingly, people with greater resources (for example, more social support from their colleagues) are less vulnerable to stress, whereas those with fewer resources (for example, less supportive colleagues) are more vulnerable to stress (Bakker, 2010). Moreover, COR theory postulates that individuals and groups strive to accumulate resources over time, and this accumulation creates "resource caravans". That is, resources tend not to exist in isolation, but rather they aggregate such that, for instance, employees working in a resourceful work environment are likely to reinforce their own resilience. In this sense, the presence of resources is crucial for the development of resilience. This process moves with increased strength as groups obtain resources, so they can look for new challenges, thereby improving their performance in order to meet the organization's assignments. Applying this logic to the study, we suggest that job social resources (i.e., social support climate and team coordination) develop team resilience and that both increase performance. Therefore we propose the following:

Hypothesis 2: Team resilience partially mediates the relationship between job resources and team performance.

Following the propositions of the JD-R model, job demands lead to threatening and stressful situations. Intuitively, one might suspect that job demands should not be important in predicting team resilience. However, as noted earlier, resilience does not refer to invulnerability in the face of stress, but rather to the ability to recover from stressful conditions. As highlighted by different authors, implicit within the notion of resilience is the exposure to significant threat or adversity (e.g., Luthar et al., 2000; Powley, 2009), and thus research on resilience needs to recognize and determine the stress or adversity encountered (Sutcliffe \& Vogus, 2003). That is, given that stressful situations are a key condition for developing resilience (Masten \& Reed, 2002), we posit that teams with higher job demands (i.e., quantitative overload, role conflict and ambiguity) will report higher resilience. No direct effect is expected between job demands and performance, and this implies that the impact of job demands on performance could be mediated by resilience. Taken together, these theoretical linkages lead to the following hypothesis: 
Hypothesis 3: Team resilience fully mediates the relationship between job demands and team performance.

In addition to the main effects of job demands and resources, the JD-R model proposes that the interaction between job demands and job resources is also significant for expected outcomes. Particularly, it suggests that job resources may buffer the negative impact of job demands and also that job resources gain their salience when job demands are high (Bakker \& Demerouti, 2007). In this study, we based on this last assumption and suggest that job resources gain their positive potential on resilience particularly when teams are confronted with high job demands. In fact, is in stressful situations when resilience needs to be developed and a strengthened relationship between resources and resilience is expected. In line with this proposition, we argue that job demands could moderate the relation between job resources and resilience. Thus, we expect:

Hypothesis 4: Job demands moderate the positive relationship between job resources and resilience such that when demands are high, resources have a stronger relationship with resilience.

\section{Method}

\section{Sample and Procedure}

The sample consisted of 1633 employees nested in 275 teams from 52 Spanish companies (Small and Medium Enterprises - SME). Thirty-five companies belonged to the service sector (66.3\% of employees), twelve to industry (27.2\% of employees), four to construction ( $4.3 \%$ of employees), and one to agriculture (2.3\% of employees). The size of the teams ranged from 2 to 44 employees, with an average of 5.94 ( $\mathrm{SD}=5.74$ ). Of the participants, $55.8 \%$ were male, and $83.6 \%$ of them had an open-ended employment contract. The average job tenure in the organization was 6.85 years $(\mathrm{SD}=6.59)$.

In order to collect the data, we previously contacted the key stakeholders in each organization (i.e., CEOs, Human Resources Managers, and Risk-and-Safety Prevention Managers) to explain the purpose and requirements of the study. Secondly, we explained that participation in this study was voluntary, that only aggregated data would be reported, and that all identifying information would be removed. Employees were considered to be members of a team when they had the same supervisor and set of standards and principles in order to achieve common goals, although they had 
interdependent tasks. In order to recognize membership of the team, we included a matched code number on the front page of the questionnaires. Finally, each employee who had been in the enterprise for at least six months was given a copy of the questionnaire, because it was found that team resilience is related to team outcomes only after teams have had extensive prior interaction (West et al., 2009).

\section{Measures}

The variables were measured with previously validated scales and reworded using “teams" as a reference (Salanova et al., 2012). Internal consistency (Cronbach's $\alpha$ ) for the scales reached the cut-off point of .70 (Nunally \& Bernstein, 1994). All items were scored on a 7-point scale ranging from 0 (never/completely disagree) to 6 (always/completely agree).

Job demands. Three job demands were measured, each composed of three items: quantitative overload (Beehr, Walsh, \& Taber, 1976; e.g., "In my team, we have more work than we can really do"), role ambiguity (Rizzo, House, \& Lirtzman., 1970; e.g., "In my team, we have disorganized tasks"), and role conflict (Rizzo et al., 1970; e.g., "In my team, we do tasks which we do not agree on"). Alphas were $.86, .83$, and .82 respectively.

Job resources. Two job resources were measured, each composed of three items: social support climate (Van Muijen et al., 1999; e.g., "In my team, our immediate supervisor attends our personal problems"), and team coordination (Salanova et al., 2012; e.g., "My team is well-coordinated"). Alphas were .76 and .77, respectively.

Team Resilience. Team resilience was measured with a scale composed of seven items, each of them based on one of Mallak's (1998) principles for implementing resilience in organizations, for example: perceive experiences constructively, perform positive adaptive behaviors, and develop tolerance for uncertainty. Conversely to previous measures of team resilience (see e.g., West et al., 2009), this scale was developed specifically referring to teams in an organizational context. A sample item is: "In difficult situations, my team tries to look for the positive side". The alpha value was .83 .

Team Performance. We use the three-item Goodman and Svyantek (1999) scales, reworded at the team level for both in-role (e.g., "My team performs all the functions and tasks demanded by the job"), and extra-role performance (e.g., "We perform roles 
that are not formally required but which improve the organizational reputation"). Alphas were .83 and .74 , respectively.

\section{Data Aggregation}

All measures used have the team as the referent and aggregated scores were employed for a team-level analysis. According to multilevel theory, these are defined as Referent-Shift Consensus Composition (Chan, 1998), meaning that there is a shift in the referent prior to consensus assessment. To statistically demonstrate within-team agreement and between-team differences, we conducted several tests: the Average Deviation Index $\left(\mathrm{AD}_{\mathrm{M}(\mathrm{J})}\right)$ was used to assess within-group agreement; the intraclass correlation coefficient - ICC(1) - was used to assess reliability; and one-way analyses of variance (ANOVA) were used to test for the existence of statistically significant differences between teams. Conventionally, an $\mathrm{AD}_{\mathrm{M}(\mathrm{J})}$ equal to or less than 1 is considered sufficient evidence of team agreement (Burke et al., 1999), whereas values greater than .05 for ICC(1) are considered sufficient evidence to justify aggregation (Bliese, 2000). Moreover, an ANOVA $F$ value that is statistically significant is a condition that justifies the aggregation of scores at the team level (Kenny \& LaVoie, 1985). From our measurements, the $\mathrm{AD}_{\mathrm{M}(\mathrm{J})}$ and $\mathrm{ICC}(1)$ indices were found to range from .57 to 1.00 and from .10 to .25 , respectively. One-way ANOVA $F$ values ranged from 1.66 to $2.96(p<.001)$. Thus, we found empirical justification for aggregation.

\section{Fit Indices}

In order to test the hypotheses, we used Structural Equation Modeling (SEM) by AMOS 19.0 (Arbuckle, 2010). Maximum likelihood estimation methods were used by computing the absolute and relative indices of goodness-of-fit (Marsh et al., 1996), i.e., the $\chi^{2}$ Goodness-of-Fit Statistic and the Root Mean Square Error of Approximation (RMSEA), as well as the Normed Fit Index (NFI), the Incremental Fit Index (IFI), the Tucker-Lewis Index (TLI), and the Comparative Fit Index (CFI). Values below .06 for RMSEA indicate a good fit. For the remaining indices, values greater than .90 indicate a good fit, whereas values greater than 95 indicate superior fit (Hu \& Bentler, 1999).

\section{Results}

\section{Descriptive analyses}

Table 3.1 shows means, standard deviations, aggregation statistics, and correlations of all the study variables. Most of the correlations are significant and in the 
Table 3.1

Means, standard deviations, aggregation indices, reliability, and correlations for the study variables

\begin{tabular}{lccccccccccc}
\hline & $M(S D)$ & $I C C(1)$ & $A D_{M(J)}$ & 1 & 2 & 3 & 4 & 5 & 6 & 7 & 8 \\
\hline 1. Quantitative overload & $3.04(1.55)$ & .24 & .94 & $. .83)$ & $.46^{* *}$ & $.46^{* *}$ & -.09 & $-.17^{* *}$ & $-.16^{* *}$ & $-.28^{* *}$ & $-.18^{* *}$ \\
2. Role ambiguity & $1.44(1.47)$ & .25 & .83 & $.47^{* *}$ & $(.82)$ & $.69^{* *}$ & $-.32^{* *}$ & $-.37^{* *}$ & $-.30^{* *}$ & $-.32^{* *}$ & $-.25^{* *}$ \\
3. Role conflict & $2.06(1.47)$ & .21 & .93 & $.45^{* *}$ & $.70^{* *}$ & $(.83)$ & $-.36^{* *}$ & $-.36^{* *}$ & $-.38^{* *}$ & $-.35^{* *}$ & $-.28^{* *}$ \\
4. Social support climate & $3.69(1.58)$ & .24 & 1 & $-.13^{* *}$ & $-.34^{* *}$ & $-.35^{* *}$ & $. .77)$ & $.48^{* *}$ & $.39^{* *}$ & $.29^{*}$ & $.36^{* *}$ \\
5. Coordination & $4.63(1.21)$ & .11 & .80 & $-.16^{* *}$ & $-.34^{* *}$ & $-.30^{* *}$ & $.46^{* *}$ & $(.76)$ & $.45^{* *}$ & $.38^{* *}$ & $.40^{* *}$ \\
6. Team resilience & $4.41(.95)$ & .15 & .75 & $-.17^{* *}$ & $-.31^{* *}$ & $-.32^{* *}$ & $.37^{* *}$ & $.42^{* *}$ & $(.85)$ & $.52^{* *}$ & $.53^{* *}$ \\
7. In-role performance & $4.89(.85)$ & .10 & .57 & $-.17^{* *}$ & $-.29 * *$ & $-.29 * *$ & $.22^{* *}$ & $.43^{* *}$ & $.49^{* *}$ & $(.81)$ & $.69^{* *}$ \\
8. Extra-role performance & $4.84(.96)$ & .16 & .69 & $-.12^{* *}$ & $-.24 * *$ & $-.24 * *$ & $.35^{* *}$ & $.45^{* *}$ & $.52^{* *}$ & $.61 * *$ & $(.72)$
\end{tabular}

Notes: Correlations are presented at the individual-level $(\mathrm{N}=1633$, below the diagonal) and at the team-level $(\mathrm{N}=275$, above the diagonal). Coefficient alpha reliability is listed in the diagonal in parentheses.

$* p<.05 ; * * p<.01$ 
expected direction. However, there was an unexpected result consisting in the negative correlations between job demands and resilience.

Because data were self-reported from one source, there are potential concerns that the results might be influenced by common method variance. Using AMOS 20.0, we conducted a Harman's one-factor test (Podsakoff, MacKenzie, Lee, \& Podsakoff, 2003), which failed to demonstrate a single factor. The results revealed a poor fit of the onefactor model to the data: $\chi^{2}(350)=2014.492, \mathrm{RMSEA}=.132, \mathrm{NFI}=.483, \mathrm{IFI}=.530$, $\mathrm{TLI}=.446, \mathrm{CFI}=.523$. To confirm these results, additional analyses were performed following the procedure recommended by Podsakoff and colleagues (2003). This approach involves adding to the researcher's theoretical model a first-order factor with all of the measures as indicators. The results revealed that the model fit improved, although none of the path coefficients corresponding to relationships between the indicators and the general method factor were significant. This finding suggested that while method bias may be present, it do not significantly affect results or conclusions (Conger, Kanungo, \& Menon, 2000).

\section{Hypothesis testing}

According to Brown (2006), in cases in which it may be necessary to use single indicators in a SEM, measurement error can be readily incorporated into a dimensional indicator by fixing its unstandardized error to some non-zero value, calculated on the basis of the measure's sample variance estimate and known psychometric information. Thus, we fixed the unstandardized error of the indicator of resilience with the formula: variance* $(1-\alpha)$.

To compute SEM, we used the aggregated database. Firstly, two competitive models were tested. First, we tested our full mediation research model (M1). This model tested the fully mediating effects of team resilience between job demands - resources on one hand and performance on the other. The results of M1, as depicted in Table 3.2, show that the fully mediating model fits the data well. The path from job resources to resilience was positive and statistically significant, as was the path from resilience to team performance. However, the path from job demands and resilience was not statistically significant. Then, we tested a competitive partial mediation model (M2) that allowed direct paths from (i) job demands to performance; and (ii) job resources to performance. Model 2 had a statistically better fit than M1, $\Delta \chi^{2}{ }_{\text {M1-M2 }}(2)=11.512$, $p<.01$. Thus, Model 2, represented in Figure 3.1, was the best-fitting model. 
Table 3.2

Results of mediated and moderated SEM analyses $(N=275$ Teams $)$

\begin{tabular}{ccccccccc}
\hline Model & $\chi 2$ & df & RMSEA & NFI & IFI & TLI & CFI & $\Delta \chi 2$ \\
\hline M1 & 38.005 & 17 & .067 & .953 & .973 & .955 & .973 & \\
M2 & 26.493 & 15 & .053 & .967 & .985 & .972 & .985 & M1-M2 $(2)=11.512, p<.01$ \\
M3 & 63.152 & 24 & .077 & .924 & .952 & .926 & .951 & \\
M4 & 45.500 & 22 & .062 & .945 & .971 & .952 & .971 & M3-M4(2) = 17.652, $p<.001$ \\
M5 & 30.518 & 19 & .047 & .963 & .986 & .973 & .986 & M4-M5(3) = 14.982, $p<.005$ \\
\hline
\end{tabular}

Note. $\chi^{2}=$ Chi-square; $\mathrm{df}=$ Degree of freedom; RMSEA = Root Mean Square Error of Approximation; NFI $=$ Normed Fit Index; IFI $=$ Incremental Fit Index; TLI $=$ TuckerLewis Index; CFI = Comparative Fit Index

To assess the mediating paths, the Sobel (1988) test was used. Results from this test supported the mediating role of resilience between job resources and team performance, $\mathrm{Z}=4.66, \mathrm{p}<.001$. However, the mediating role of resilience between job demands and team performance was not supported, $\mathrm{Z}=.90, \mathrm{p}=.37$. We also performed the four steps for testing for mediation proposed by Baron and Kenny (1986). According to these steps: (1) the independent variables should be related to the dependent variable; (2) the independent variables should be related to the mediator; (3) the mediator should be related to the dependent variable, controlling for the independent variables; and (4) for full mediation, the effect of the independent variables on the dependent variable is reduced to non-significance when the mediator's effect on the dependent variable is taken into account. If the fourth condition is not met, partial mediation is concluded. As previously noted, the Sobel test did not support the mediating role of resilience between job demands and team performance, and the paths from job demands to team resilience/performance were not significant, so we do not report the results of Baron and Kenny's steps for the job demands paths, but only for job resources. There was a significant positive effect of job resources on performance, $\beta=.56, \mathrm{p}<.001$, and on resilience, $\beta=.60, \mathrm{p}<.001$. When both job resources and resilience were included as predictors in the regression equation, job resources still predicted performance, $\beta=.27, p<.05$, as did resilience, $\beta=.48, p<.001$. These 
Figure 3.1. The final model with standardized path coefficients $(N=275)$. Dotted lines show no significant paths.

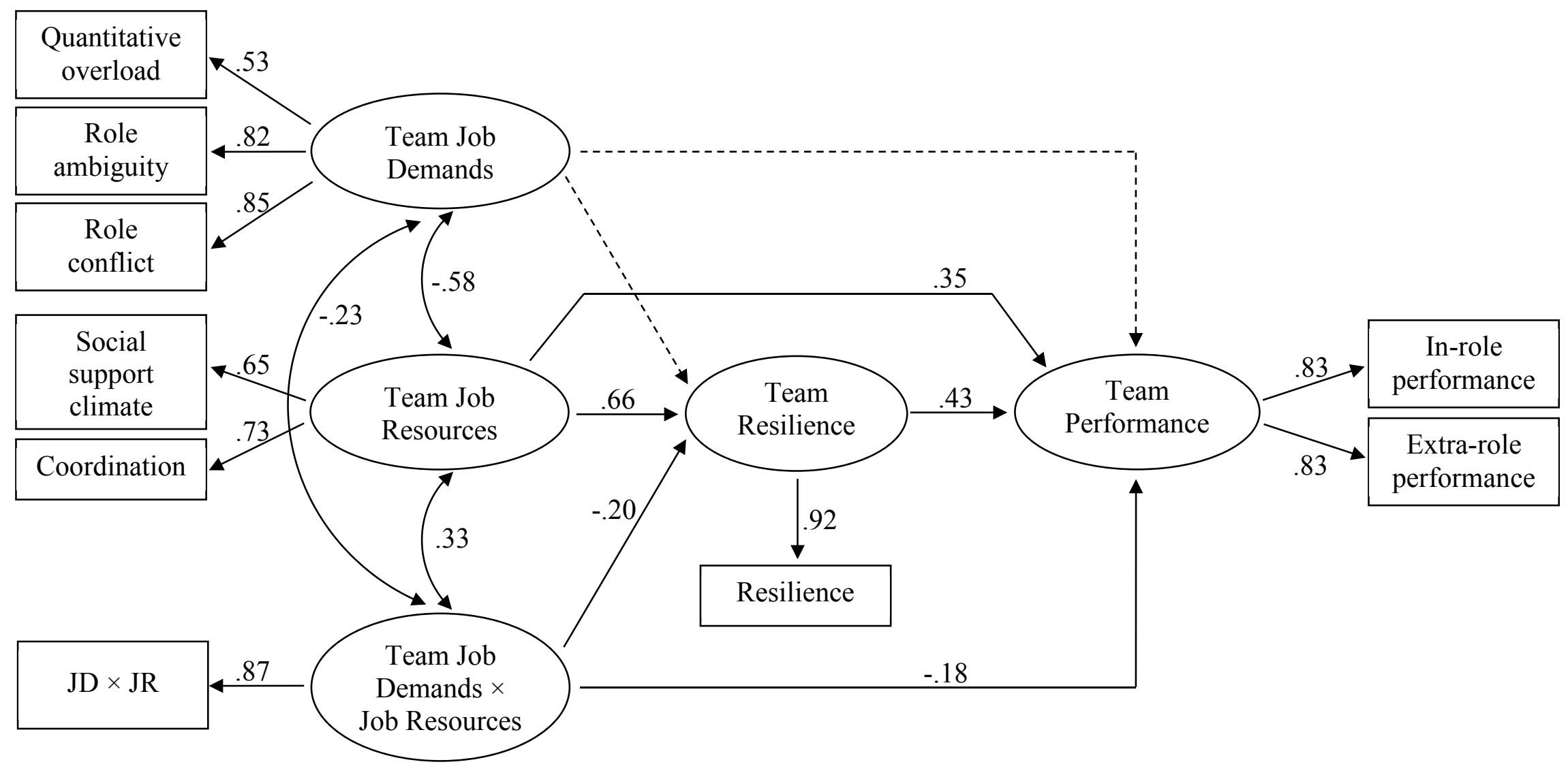


results suggest that the effect of job resources on performance was partially mediated by resilience.

Then, to explore the validity of the moderation hypothesis, we conducted MSEM in order to test the First Stage Moderation Model (Edwards \& Lambert, 2007). The procedure outlined by Ping (1995), as reported in Cortina, Chen and Dunlap (2001), was followed to conduct the analyses. A significant interaction effect is supported when the path coefficient from the latent interaction factor to the latent endogenous factor is significant. Our MSEM analysis included three exogenous latent factors (job demands, job resources, and their interaction), a mediating latent factor (team resilience), and an endogenous latent factor (team performance). Table 3.2 reports the results of this analysis (M3). The interaction factor showed a weak but statistically significant path in the unexpected direction, $\gamma=-.14, \mathrm{p}<.05$. Overall, the fit of Model 3 was not really adequate. This misfit was mainly due to the substantial relationship between the interaction factor and its component factors, which were not eliminated by the preliminary centering operations (Cortina et al., 2001). Thus, we freed all the covariance between the latent exogenous factors in Model 4 (M4). As a result, the fit of the model substantially improved and the path from the interaction factors to resilience showed a greater effect, $\gamma=-.20, p<.01$.

Finally, we tested a Direct Effect and First Stage Moderation Model (Edwards \& Lambert, 2007), where job demands further moderated the direct relationship between job resources and team performance (Model 5). The procedure outlined by Ping (1995) was followed once again to conduct the analyses. Building upon the previous moderation analysis, we estimated all the covariance between the latent exogenous factors in this analysis. Table 3.2 reports the results (M5). The interaction factor showed a statistically significant path to performance, $\gamma=-.18 p<.05$, as well as to resilience, $\gamma=-.20, p<.001$. The results of M5, which is presented graphically in Figure 3.1, showed the double moderating effect of job demands: on both the job resourcesresilience and the job resources-performance relationships. The simple slope analysis showed the double moderating effect of job demands: on both the job resources-team resilience (Figure 3.2) and the job resources-team performance relationships (Figure 3.3). It is interesting to note that job demands, resources, and their interaction explain $47 \%$ of the variance of resilience $(\mathrm{R} 2=.47)$, which in turn explains $56 \%$ of the variance of performance $(\mathrm{R} 2=.56)$. 
Figure 3.2. Simple-slope analysis of the effect of the interaction between job demands and job resources on team resilience.

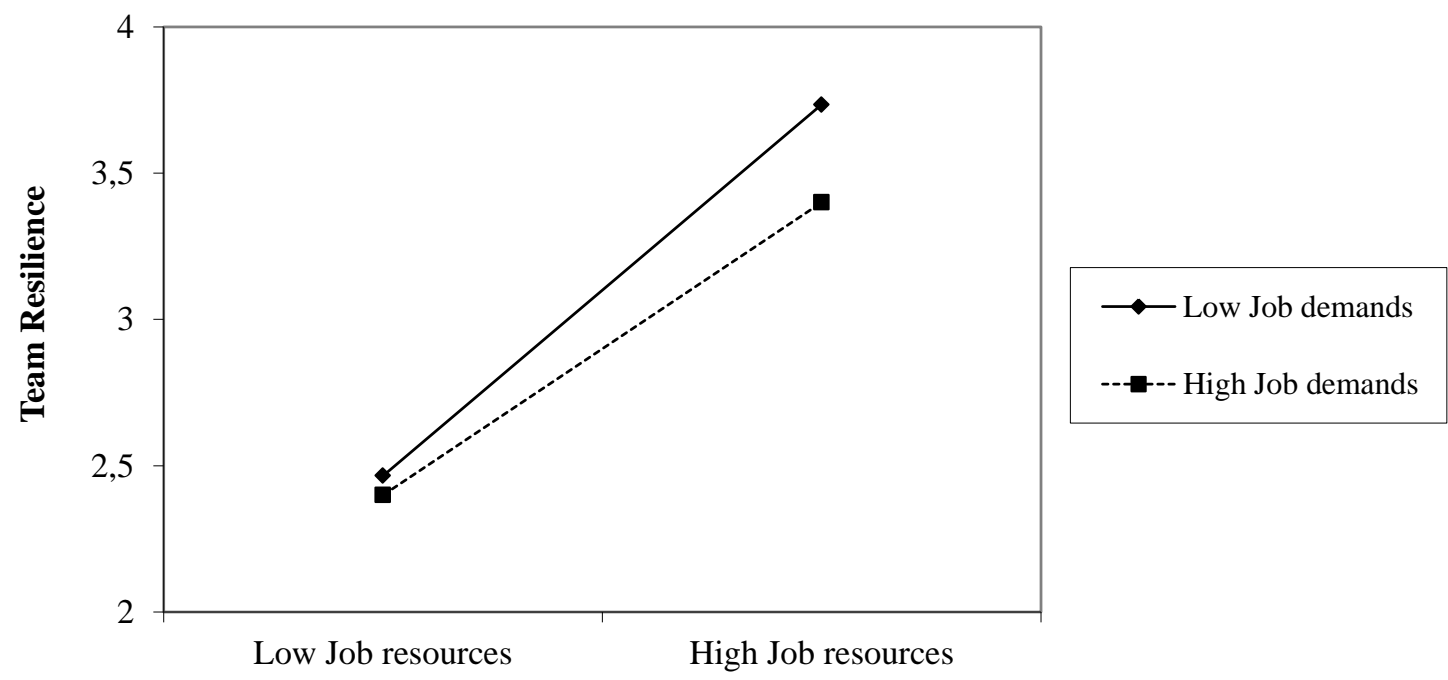

Figure 3.3. Simple-slope analysis of the effect of the interaction between job demands and job resources on team performance.

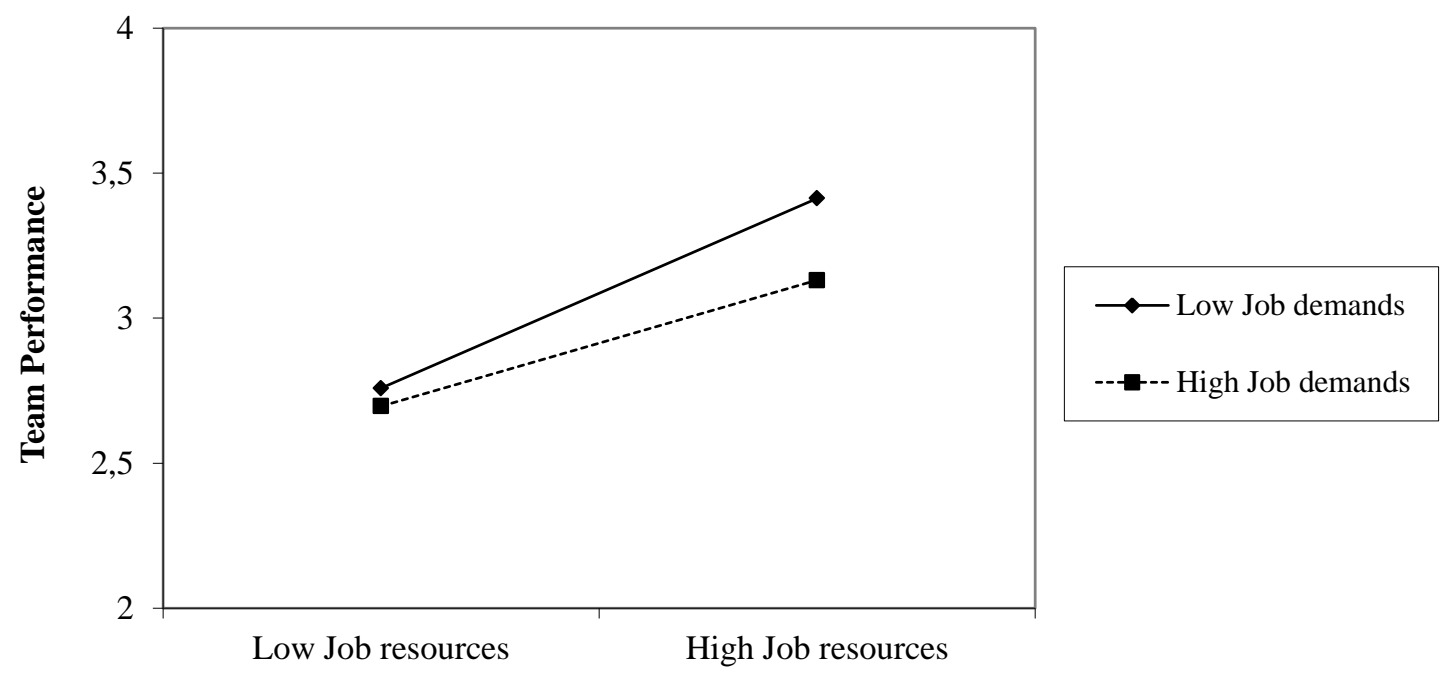




\section{Discussion}

Constant unstable and turbulent work environment that bring about numerous stresses to organizations, as well as their teams and employees, have become one of the features of organizational life (Lengnick-Hall, Beck, \& Lengnick-Hall, 2011). For improve successful adjustment, and thus achieve positive outcomes in these situations, managers and HRM professionals have to assist employees and teams in develop their resilience. Especially for the importance of teams in actual work-based structure, it is crucial to understand the antecedents and consequences of teams' resilience, in order to recognize how team inputs are transformed into outcomes (Mathieu, Maynard, Rapp, \& Gilson, 2008). Accordingly, the main purpose of the study was to recognize team resilience as a psychological mechanism that explains how teams deal with job demands and job resources, in order to achieve better performance. The results of SEM and MSEM analyses partially supported our hypotheses, indicating that team resilience is positively related with team performance (confirming Hypothesis 1) and also partially mediates the effects of job resources on team performance (confirming Hypothesis 2), whereas it does not mediate the effects of job demands on team performance (weakening Hypothesis 3). However, it was shown that job demands operate as a significant moderator in the model tested (confirming Hypothesis 4).

\section{Theoretical contributions}

The findings of this study are important for research in several ways. Firstly, the results not only indicated that job resources are related to team performance, but also added team resilience as a significant mediator. Thus, this study provides evidence that job social resources and team resilience are important in eliciting organizations' desirable outcomes such as team performance. Secondly, the findings indicated that, in contrast to our expectations, job demands do not directly impact team resilience. This finding is surprising because in the process of resilience the experience of adversity is important in order to enhance it (Luthar et al., 2000) and even the correlations were significant and moderate in magnitude. However it may suggest that, for work teams, high levels of job demands might create an opportunity for developing future levels of resilience while at the same time diminishing current levels of resilience. Moreover, taking into account the distinction between challenges and hindrance demands (for a meta-analysis, see Crawford, LePine, \& Rich, 2010), we used job demands belonging to both categories and for this reason the relationship could not be significant. We argue 
that only challenging demands might be related to resilience, because they are usually perceived as opportunities to learn, achieve, and demonstrate the type of competence that tends to get rewarded. Taking into account a greater number of job demands in both categories, future research should investigate the effects of these categories on resilience in order to understand how the results may differ.

Nevertheless, moderation analyses revealed a significant effect of job demands on the relationship between job resources and team resilience, as well as between job resources and team performance. Specifically, the impact of job resources on team resilience is attenuated when there are high job demands, suggesting that job demands do impact team resilience but the nature of their impact depends on other factors such as the amount of resources. These findings seem to call for more research, particularly because the JD-R model originally suggested that job resources gain their motivational potential particularly when employees are confronted with high job demands (Bakker \& Demerouti, 2007). A possible explanation is given by models of effort and energy regulation, which propose that high demands require a high degree of effort investment (Hockey, 1997) and subsequently drain energy resources. Consequently, job demands reduce a person's energy level over time, thus initiating a "loss spiral" (Hobfoll, 2001) that reduces personal resources.

Finally, the results showed that team resilience is related to team performance, underlining the fact that a high level of team resilience might lead to the best performance, in accordance with previous studies carried out at the individual level (e.g., Luthans et al., 2005; Youssef \& Luthans, 2007). Altogether, this finding seems to call for more research into team resilience, particularly because teams play a crucial role in achieving important organizational outcomes (West et al., 2009).

\section{Implications for Practice}

In terms of practical implications, our results suggest that, besides work characteristics, team resilience is also important for enhancing team performance in organizations. These results present a number of potential applications and encourage initiatives to make managers and HRM professionals pay closer attention to the wellbeing of their teams, particularly in the context of the current economic crisis. First, they can facilitate and enhance positive relationships and cooperation among team members. For example, it has been shown that face-to-face meetings can allow individuals and team members to feel more connected with their co-workers 
(Warkentin, Sayeed, \& Hightower, 1997). It could also be important to develop respectful interaction, defined as face-to-face, on-going dialogs rooted in trust, honesty, and self-respect (Weick, 1993) because they are a key factor enabling collaboration (Lengnick et al., 2011).

Second, managers and HRM professionals concerned with slowing down demanding aspects of work could assess teams' workloads to ensure that they match their skills and capacities. Moreover, they could be especially incisive in creating fluid team-based work and job design, and in generating broader job descriptions, while managers could also attempt to clarify team (and employee) roles and responsibilities. In addition, as an example, it was also shown that congruence between the values of employees and organizations might reduce role ambiguity and role conflict (Edwards \& Cable, 2009). Thus, managers and HRM professionals might invest energy and resources to assess value congruence when hiring job applicants, engage in socialization tactics to modify the values of new employees in the direction of the cultural values of the organization, and ensure that organizational communication is regular, open, and consistent (Cable \& Judge, 1997; Cable \& Parsons, 2001; Edwards \& Cable, 2009).

Finally, recognition of the fact that certain types of resources contribute to the development of resilience and increase performance should help organizations to develop improved HR policies aimed at reinforcing a climate of security and collaboration needed for the intricate mix of expertise, opportunism, creativity, and decisiveness that enables sense-making and adherence to core values to thrive despite the uncertainty triggered by crises (Lengnick et al., 2011).

\section{Limitations}

Although our study findings pointed to some noteworthy conclusions, our methods suffered from limitations that should be addressed in future research. First, use of cross-sectional design, whereas studies in a longitudinal way are necessary in order to establish causal relationships. Second, our study is open to the typical criticisms of single-source, self-report data, especially for team performance measure. Although our tests fail in showing a significant common method effect, this may introduce a bias so that in future studies it would be interesting to include another measurement source. Nevertheless, the high level of agreement among the workers in the same team assessed by $\mathrm{ICC}(1), \mathrm{AD}_{\mathrm{M}(\mathrm{J})}$, and one-way ANOVAS- is a strength in this sense, because it shows that there is agreement among the teammates' perceptions. A final limitation of 
the present study is its lack of generalizability to the entire working population, because we used a convenience sample. However, we believe that a sample of 275 teams from different business sectors is a good achievement.

\section{Concluding Remarks}

The main objective of resilience is to find unknown inner strengths and outer resources, thereby allowing workers to be more skilled so that problems can be overcome and the organization can thrive and flourish despite adversity. Our findings suggest that managers and HRM professionals could benefit from understanding how team resilience could be developed given that team resilience aids to achieve positive team outcomes. Furthermore, we believe that this study makes an interesting contribution to the resilience literature by providing evidence for its applicability at the team level in the organizational context. 


\title{
CHAPTER 4
}

\section{Feeling good makes us Stronger: How Team Resilience Mediates the effect of Positive Emotions on Team Performance ${ }^{3}$}

\begin{abstract}
This study investigated the relationship between collective positive emotions at work and team resilience, expanding on the Broaden \& Build Theory of Fredrickson (1998; 2001) at the collective (i.e., work teams) level of analysis. Through the aggregate scores of 1076 employees (61\% men), grouped into 216 teams and belonging to 40 companies, five collective positive emotions were evaluated (i.e., enthusiasm, optimism, satisfaction, comfort, and relaxation) as well as team resilience. Additionally, ratings of the 216 supervisors of the teams were used to assess team performance (i.e., in- and extra-role performance). Structural equation modeling at the team level of analysis indicated that team resilience mediates the relationship between collective positive emotions and team performance, both in- and extra-role. The results highlight the importance of developing collective positive emotions to help teams to foster team resilience and improve their performance. The article concludes with practical strategies aimed at developing collective positive emotions, together with limitations and suggestions for future research.
\end{abstract}

Key words: Collective Positive Emotions, Team Resilience, Team Performance, Broaden \& Build Theory, Structural Equation Modeling

${ }^{3}$ Chapter 4 has been submitted for publication as: Meneghel, I., Salanova, M., \& Martínez, I. M. Feeling Good makes us Stronger: How Team Resilience Mediates the effect of Positive Emotions on Team Performance. The Journal of Happiness Studies. 


\section{Introduction}

Nowadays organizations are embedded in a complex global environment, and are faced with diverse risks and potentially adverse situations that threaten the prosperity of the organization and the well-being of its members (Powley, 2009). Work stress is one of the negative outcomes that people feel in that complex work world, especially in Europe. As a matter of fact, issues of safety and health at work are a major concern to managers of European companies with a share of $79 \%$ among European managers and 82\% among Spanish executives (European Agency for Safety and Health at Work, 2010). It therefore follows that there is a need to implement strategies that provide organizations and their members with the necessary resources to deal with the risk of job stress, in order to achieve positive outcomes in stressful situations. In this sense, recent calls have been made to address the potential role of resilience (Kaplan LaPort, \& Waller, 2012).

Previous studies proposed that by developing employees' resilience the organization will become more adaptive and successful over time (Youssef \& Luthans, 2005). For example, resilient employees may use an adverse experience to increase performance in subsequent tasks, and may be far more valuable to the organization in terms of their adaptability in times of subsequent change or uncertainty (Hind, Frost, \& Rowley, 1996). Despite teams' relevance in the lives of organizations (Richter, West, van Dick, \& Dawson, 2006), research on resilience at work is usually carried out at the individual level of analysis, without taking into consideration the importance of focusing on a more collective level. However, in the same way that organizations are focusing increasingly more on the performance of their teams (Gully, Incalcaterra, Joshi, \& Beaubien, 2002), attention will also be directed toward identifying characteristics and processes that elicit positive outcomes, such as team resilience.

Although resilience is relative, emerging and changing in transaction with specific circumstances and challenges (Staudinger, Marsiske, \& Baltes, 1993), resilience developed and displayed in a certain situation will lead to better preparation for upcoming events (Egeland, Carlson, \& Sroufe, 1993). Therefore, establishing which variables help the development of team resilience is essential to better prepare teams to respond to future adverse situations. A considerable amount of research confirms the importance of positive emotions for the development of resilience (i.e., Cohn, Fredrickson, Brown, Mikels, \& Conway, 2009; Loh, Schutte, \& Thorsteinsson, 2014), although it is commonly at the individual level and evidence at the team level is lacking. 
Based on the Broaden-and-Build (B\&B) Theory of positive emotions by Fredrickson (1998; 2001), in this study we investigated the predicting role of collective positive emotions on (team) resilience. Moreover, we examine whether the relationship between collective positive emotions and team resilience stimulated positive team outcomes, such as in- and extra-role performance. Overall the present study aims to understand more about how collective positive emotions drive the within-team experience to promote favorable reactions (i.e., resilience) among teams, in order to achieve better team performance.

The novelty of this study lies in the fact that it expands on previous research in this field in several ways. First, although earlier studies have already examined positive emotions as predictors of resilience, the analyses were at the individual level of analysis. Instead, we used aggregated scores for a team-level analysis (cf. Referent-Shift Consensus model; Chan, 1998). Second, we include the supervisors' ratings as measures of team performance, in order to obtain a more objective evaluation of these variables and better control for method bias, thereby strengthening the validity of our results. Finally, because performance is usually considered multidimensional (Borman \& Motowidlo, 1993), we include the two main components of team performance (i.e., inand extra-role) and analyze the different impacts of team resilience on each of them.

\section{Defining Team Resilience}

Within the domain of organizational psychology and management, the concept of resilience has been used to refer to relatively ordinary adaptive processes when encountering unexpected, adverse conditions that result either from large-scale disturbances or the accumulation of several minor disruptions (Sutcliffe \& Vogus, 2003). Positive psychology has embraced resilience as a prime example of what is right and good about people (Luthans, Vogelgesang, \& Lester, 2006), because the main aim of positive psychology is to study "conditions and processes that contribute to the flourishing or optimal functioning of people, groups, and institutions" (Gable \& Haidt, 2005; p. 104). The resilience approach recognizes the need for flexibility, adaptation, and improvisation in situations characterized by change and uncertainty (Youssef \& Luthans, 2007). In this regard, resilience must help organizations, as well as their members and teams, to deal with adverse and stressful situations, so that they can be overcome and positive organizational outcomes can be achieved (Kaplan et al., 2012). 
Resilience may be considered as much an individual characteristic as a social factor in teams or groups (Bennett, Aden, Broome, Mitchell, \& Rigdon, 2010). Consistent with social identity theory (Tajfel \& Turner, 1985), individuals identify with their team and internalize its values and norms, which lead to homogeneity in attitudes and behaviors. Empirical evidence gives support to show that, in a similar way to individuals acting alone, individuals performing as teams tend to display somewhat regular patterns of behavior and processes (Stewart, 2010). In order to provide a possible explanation for this, Totterdell (2000) stated that "team members could respond similarly to shared events and therefore end up feeling the same way" (p. 848) - in our case sharing the same level of team resilience. Thus, in our study we focus on team resilience, defined as "the capacity to bounce back from failure, setbacks, conflicts, or any other threat to well-being that they may experience" (West, Patera, \& Carsten, 2009, p. 253).

\section{Collective Positive Emotions and Team Resilience}

The B\&B Theory of positive emotions by Fredrickson $(1998,2001)$ offers a theoretical explanation by linking accumulated experiences of positive emotions with the development of resources for long-term success and well-being. Specifically, the B\&B Theory assumes that positive emotions appear to broaden people's momentary thought-action repertories and to build their enduring personal resources, such as resilience (Fredrickson, Tugade, Waugh, \& Larkin, 2003; Tugade \& Fredrickson, 2004). The difference in positive emotions accounts for the ability to rebound from adversity and stress, and continue to grow. That is, momentary experiences of positive emotions produce patterns of thought that are particularly unusual, flexible, creative, and open to information (Isen, 2000). Over time, these extended attitudes create lasting personal resources, ranging from physical and intellectual to social and psychological resources (Fredrickson, 2001).

A significant amount of previous research supported the B\&B theory, and specifically found that recurrent experiences of positive emotions are related to individual resilience. First, it has been shown that positive emotions can boost resilience (Algoe \& Fredrickson, 2011; Cohn et al., 2009) and that people who are particularly adept at self-generating positive emotions are more likely to be resilient (Tugade \& Fredrickson, 2004). Furthermore, a positive reciprocal impact of positive emotions and resilience was suggested in such a way that these momentary experiences of positive 
emotions can build resilience and trigger gain spirals over time, which in turn may produce greater emotional well-being (Fredrickson \& Joiner, 2002). These relationships were replicated in the study by Ong, Bergeman, Bisconti, and Wallace (2006). In particular, it was shown that: i) the adaptation benefits of positive emotions are greater when people are under stress, ii) positive emotions are more common among more resilient persons, and iii) over time, positive emotions serve to help resilient people in their ability to effectively recover from adversity.

In the organizational context, the importance of emotions is firmly established, and researchers have begun to turn their attention toward understanding the processes and outcomes of collective emotion (Barsade, 2002). It has been shown that common beliefs and shared emotional experiences emerge among people working together, leading to similar motivational and behavioral patterns, and shared emotions (Barsade, 2002; George, 1990). Three main mechanisms have been proposed to explain the emergence of (positive) collective emotion development, namely emotional contagion (Hatfield, Cacioppo, \& Rapson, 1992), emotional comparison (Schachter, 1959), and empathy (Hoffman, 1985). Whereas emotional contagion denotes a subconscious process of aligning each other's affective reactions, emotional comparison is a more conscious mechanism to compare one's own feelings with those expressed by others, in order to show appropriate and congruent affective reactions (Barsade, 2002). In contrast, empathy is based on vicarious affect and team members show similar affectivity by deliberately assuming others' psychological points of view (Nelson Klein, \& Irvin, 2003).

In accordance with these mechanisms, affective responses and emotions within team members can converge and the team can easily achieve a collective mood. Subsequently, in the same way as individuals (Fredrickson \& Losada, 2005), positive collective emotions are associated with an enhancement in the availability of team resources and resilience to adversity. This theoretical and empirical evidence allows us to go a step further in the $\mathrm{B} \& \mathrm{~B}$ theory, in order to verify whether the relationship between positive emotions and resilience is replicated at the collective (team) level in the work context. We therefore expect that:

Hypothesis 1: Collective positive emotions in work teams are positively related to team resilience. 


\section{Team Resilience and Team Performance}

Furthermore, we assumed that team resilience has a positive relationship with team performance because, compared to less resilient teams, teams with a high level of resilience are likely to come up with more flexible and adaptive responses to adversity, and additionally they tend to use setbacks as challenges or opportunities for growth (Carmeli, Friedman, \& Tishler, 2013). Thus, teams which display the ability to thrive in situations of adversity, improvise and adapt to significant change or stress, or just recover from a negative experience will be less likely to experience the potentially damaging effects of threatening situations, and thus their performance will be high (West et al., 2009).

Previous evidence revealed that team resilience is positively related with team performance (Salanova, Llorens, Cifre, \& Martínez, 2012), as well as team cohesion, cooperation, and coordination (West et al., 2009). However these results reflect selfreported measures of team outcomes, whereas the current study considers performance assessed by the immediate supervisor of each team. In the literature, performance is usually divided into in-role performance (similar to task performance), defined as fulfillment of tasks that employees are expected to carry out as part of the formal job requirements, and extra-role performance (similar to contextual performance), defined as behavior that is beneficial to the organization and goes beyond formal job requirements (e.g., helping colleagues at work, making suggestions for improvement; Borman \& Motowidlo, 1993; Goodman \& Svyantek, 1999). In this study both kinds of performance are taken into account, and team resilience is expected to be related not only to in-role but also to extra-role performance. Extra-role performance is particularly relevant from a positive point of view (Avey, Luthans, \& Youssef, 2010). For example, extra-role behaviors often include actions that are helpful to other members of a group and enhance the flow of information between colleagues, assist in the development of interpersonal relationships, and encourage an atmosphere of teamwork and cooperation (O'Bannon \& Pearce, 1999). Moreover, the integration of both indicators of performance is more likely to capture overall performance in a broader, holistic sense (Harter, Schmidt, \& Keyes, 2003). We therefore expect that:

Hypothesis 2: Team resilience is positively associated with team performance (i.e., in- and extra-role performance). 
Finally, we postulate that the relationship of positive emotions to team outcomes is fully mediated by resilience. In fact, in accordance with the B\&B theory, positive emotions make it easier to build durable personal resources, and people who are particularly adept at self-generating positive emotions are more likely to be resilient. By contrast, no rationalization was given about the possible relationship between positive emotions and behavioral outcomes, such as work performance. Moreover, previous evidence about the thesis of "happy-productive workers" showed that (trait) psychological well-being was related to job performance, whereas (state) positive mood was not (Wright, Cropanzano, \& Meyer, 2004). Consequently, we proposed that team resilience fully mediates the relationship between collective positive emotions and team performance. That is, collective positive emotions help to build team resilience, which in turn increases team performance. Hence, we expect:

Hypothesis 3: Team resilience will mediate the relationship between collective positive emotions and team performance. Specifically, we expect collective positive emotions to be positively related to team resilience, which in turn is positively related with team performance.

\section{Method}

\section{Sample and Procedure}

The sample consisted of 1076 employees nested in 216 teams from 40 companies in Spain. Twenty-seven companies belonged to the service sector (66\% of employees), 10 to industry (28.8\% of employees), and 3 to construction (5.2\% of employees). The organizational size ranged from 10 to 171 employees, with an average of 34 (SD = 30.95). The team size ranged from 2 to 38 employees, with an average of 4.99 (SD = 4.20). Sixty-one percent of the participants were male, and $91 \%$ of them had an openended employment contract. The average job tenure in the organization was 6.93 years $(\mathrm{SD}=6.71)$.

In order to collect the data, we previously contacted the key stakeholders in each organization (i.e., CEOs, Human Resources Managers, Risk-and-Safety Prevention Managers) to explain the purpose and requirements of the study. Secondly, we explained that participation in this study was voluntary, that only aggregated data would be reported, and that all identifying information would be removed. We considered employees to be members of a team when they had the same supervisor and set of standards and principles in order to achieve common goals or purposes, although they 
had interdependent tasks. In order to recognize membership of the team, we included a team's code number on the front page of the questionnaires for each employee. Finally, in accordance with McCarthy (1992), each employee who had been in the enterprise for at least six months was given a copy of the questionnaire. This is important in studying team resilience, because previous studies found that team resilience is related to important team outcomes only after teams had extensive prior interaction (West et al., 2009).

\section{Measures}

All the variables were measured with previously validated scales (Salanova et al., 2012) and use "teams" as a reference. Internal consistency (Cronbach's alphas) for the scales reached the cut-off point of .70 (Nunnally \& Bernstein, 1994).

Collective Positive Emotions. We selected and measured five collective emotions (i.e., enthusiasm, optimism, satisfaction, comfort, and relaxation) representing how the team had felt during the last year. These emotions were chosen in order to be representative of the three principal axes proposed by Warr (1990), that is: (i) displeased-pleased, (ii) anxious-contented, and (iii) depressed-enthusiastic. The respondent is asked to choose the position he or she considers the team lies in, on a Faces Scale (Kunin, 1955) between two bipolar adjectives (e.g., Unsatisfied vs. Satisfied) ranging from 7 faces (from 0- frowning to 6- smiling). The alpha of the scale was .92 .

Team Resilience. We measured team resilience with a scale composed of seven items, each of them based on Mallak's (1998) principles for implementing resilience in organizations. In contrast to previous measures of team resilience (see for example, West et al., 2009), this scale was developed specifically referring to teams in an organizational context. Items were scored on a 7-point Likert scale ranging from 0 (never) to 6 (always). A sample item could be: "In difficult situations, my team tries to look on the positive side". The alpha of the scale was .83.

Team Performance. We used the three-item Goodman and Svyantek (1999) scales, reworded at the team level and adapted for supervisor assessment both for in-role (e.g., "The team that I supervise performs all the functions and tasks demanded by the job") and extra-role performance (e.g., "In the team that I supervise employees perform roles that are not formally required but which improve the organizational reputation"). 
Items were scored on a 7-point Likert scale ranging from 0 (completely disagree) to 6 (completely agree). Alphas were .90 and .84 , respectively.

\section{Data Aggregation}

All variables measured have the team as the referent and, in the case of positive emotions and resilience measures, aggregated scores were employed for a team-level analysis. According to multilevel theory, these are defined as Referent-Shift Consensus Composition (Chan, 1998), meaning that there is a shift in the referent prior to consensus assessment. To statistically demonstrate within-team agreement and betweenteam differences, we conducted several tests: the Average Deviation Index $\left(A D_{M(J)}\right.$; Burke, Finkelstein, \& Dusig, 1999) was used to assess within-group agreement; the intraclass correlation coefficient - ICC(1) - was used to assess reliability; and one-way analyses of variance (ANOVA) were used to test for the existence of statistically significant differences between teams. Conventionally, an $\mathrm{AD}_{\mathrm{M}(\mathrm{J})}$ equal to or less than 1 is considered sufficient evidence of team agreement (Burke et al., 1999), whereas values greater than .05 for ICC(1) are considered sufficient evidence to justify aggregation (Bliese, 2000). Moreover, an ANOVA $F$ value that is statistically significant is a condition that justifies the aggregation of scores at the team level (Kenny and LaVoie, 1985). From our measurements, the $\mathrm{AD}_{\mathrm{M}(\mathrm{J})}$ and $\mathrm{ICC}(1)$ indices were found to range from .72 to .97 and from .10 to .14, respectively. One-way ANOVA $F$ values ranged from 1.47 to 1.83 and were significant $(p<.001)$ for all variables. Thus, we found empirical justification for aggregation.

The measures of performance also have the team as the referent, but these did not need to show agreement because we only have one measure for each team -reported by the supervisor.

\section{Fit Indices}

In order to test the hypotheses, we used Structural Equation Modeling (SEM) by AMOS 21.0 (Arbuckle, 2010). Maximum likelihood estimation methods were used by computing the absolute and relative indices of goodness-of-fit (Marsh, Balla, \& Hau, 1996), i.e., the $\chi^{2}$ Goodness-of-Fit Statistic and the Root Mean Square Error of Approximation (RMSEA), as well as the Normed Fit Index (NFI), the Incremental Fit Index (IFI), the Tucker-Lewis Index (TLI), and the Comparative Fit Index (CFI). Values below .06 for RMSEA indicate a good fit. For the remaining indices, values 
greater than .90 indicate a good fit, whereas values greater than .95 indicate superior fit (Hu \& Bentler, 1999).

\section{Descriptive analyses}

Table 4.1 shows means, standard deviations, aggregation statistics, correlations, and Cronbach's alphas of all the study variables. Each collective positive emotion is positively related with the other ones, and also team in- and extra-role performances are positively related. Moreover, collective positive emotions are positively related to resilience, which in turn is positively related to team performance indicators. Finally, most of the correlations between collective positive emotions and in- and extra-role performance are significant, with the exception of the correlation between relaxation and optimism with in-role performance.

Although problems with common method bias may have been overstated (Spector, 2006), in order to mitigate the problem two procedural remedies were implemented, as suggested in Podsakoff, MacKenzie, and Podsakoff (2012). Firstly, we obtained the measures from different sources - specifically, the predictor and mediator measures from (shared perceptions of) employees and the criterion measure from direct supervisors. Secondly, we differentiated the scale properties shared by the measures of the predictor and mediator variables: collective positive emotions were scored on a "Faces Scale", whereas team resilience was scored on a "Likert Scale". Moreover, using AMOS 21.0, we conducted a Harman's one-factor test (Podsakoff, MacKenzie, Lee, \& Podsakoff, 2003), which failed to demonstrate a single factor between collective positive emotions and team resilience. The results revealed a poor fit of the one-factor model to the data: $\chi^{2}(54)=415.87, \mathrm{RMSEA}=.18, \mathrm{NFI}=.76, \mathrm{IFI}=.78, \mathrm{TLI}=.73$, $\mathrm{CFI}=.78$, but a better fit of the two-factor model: $\chi^{2}(53)=178.05$, RMSEA $=.11$, $\mathrm{NFI}=.90, \mathrm{IFI}=.93, \mathrm{TLI}=.91, \mathrm{CFI}=.92\left(\Delta \chi^{2}(1)=287.32, p<.001\right)$.

\section{Hypothesis testing}

According to Brown (2006), in cases in which it may be necessary to use single indicators in a SEM analysis, measurement error can be readily incorporated into a dimensional indicator by fixing its unstandardized error to some non-zero value, calculated on the basis of the measure's sample variance estimate and known psychometric information (e.g., internal consistency). Thus, we fixed the unstandardized error of the indicator of team resilience, in-role performance, and extrarole performance with the formula: variance*(1-alpha). 
Table 4.1

Means, standard deviations, aggregation indices, reliability, and correlations for the study variables

\begin{tabular}{lccccccccccc}
\hline & $M(S D)$ & $I C C(1)$ & $A D_{M(J)}$ & 1 & 2 & 3 & 4 & 5 & 6 & 7 & 8 \\
\hline Collective enthusiasm & $3.61(.99)$ & .12 & .93 & - & $.70^{* *}$ & $.68^{* *}$ & $.73^{* *}$ & $.66^{* *}$ & $.40^{* *}$ & - & - \\
Collective optimism & $3.97(1.01)$ & .14 & .94 & $.76^{* *}$ & - & $.71^{* *}$ & $.72^{* *}$ & $.55^{* *}$ & $.43^{* *}$ & - & - \\
Collective satisfaction & $3.92(1.03)$ & .12 & .97 & $.70^{* *}$ & $75^{* *}$ & - & $.74^{* *}$ & $.55^{* *}$ & $.43^{* *}$ & - & - \\
Collective comfort & $4.09(.97)$ & .10 & .94 & $.78^{* *}$ & $.75^{* *}$ & $.77^{* *}$ & - & $.61^{* *}$ & $.42^{* *}$ & - & - \\
Collective relaxation & $3.09(1.11)$ & .14 & .95 & $.68^{* *}$ & $.56^{* *}$ & $.57^{* *}$ & $.64^{* *}$ & - & $.29^{* *}$ & - & - \\
Team resilience & $4.46(.58)$ & .12 & .72 & $.59^{* *}$ & $.59^{* *}$ & $.56^{* *}$ & $.58^{* *}$ & $.41^{* *}$ & $(.85)$ & - & - \\
In-role performance & $4.64(.93)$ & - & - & $.17^{*}$ & .13 & $.17^{*}$ & $.20^{* *}$ & .07 & $.17^{*}$ & $(.86)$ & - \\
Extra-role performance & $4.55(1.00)$ & - & - & $.26^{* *}$ & $.15^{*}$ & $.21^{* *}$ & $.26^{* *}$ & $.16^{*}$ & $.19^{* *}$ & $.72^{* *}$ & $(.79)$
\end{tabular}

Notes: Correlations are presented at the individual-level $(\mathrm{N}=1076$, above the diagonal) and at the team-level $(\mathrm{N}=216$, below the diagonal). Coefficient alpha reliability estimates are listed in the diagonal in parentheses.

$* p<.05 ; * *<.01$ 
To compute SEM, we used the aggregated database $(\mathrm{N}=216)$. Because we expected a full mediation of team resilience between collective positive emotions and team performance, we tested the full mediation research model (M1). This model tested the fully mediating effects of team resilience between collective positive emotions, on the one hand, and both indicators of team performance on the other. The results of M1, as depicted in Table 4.2, show that the fully mediating model fits the data well. The path from collective positive emotions to resilience was positive and statistically significant $(\beta=.71, p<.001)$, as was the path from resilience to team in-role performance $(\beta=.20, p<.01)$ and extra-role performance $(\beta=.25, p<.01)$. This finding supported our Hypotheses 1 and 2 .

Table 4.2

Results of SEM analyses $(N=216$ Teams $)$

\begin{tabular}{ccccccccc}
\hline Model & $\chi^{2}$ & df & RMSEA & NFI & IFI & TLI & CFI & $\Delta \chi^{2}(\Delta \mathrm{df})$ \\
\hline M1 & 39.82 & 19 & .07 & .96 & .98 & .97 & .98 & \\
M2 & 35.79 & 17 & .07 & .96 & .98 & .97 & .98 & M1-M2 $(2)=4.03$, ns \\
\hline
\end{tabular}

Note. $\chi 2=$ Chi-square $; \mathrm{df}=$ Degree of freedom; RMSEA = Root Mean Square Error of Approximation; NFI = Normed Fit Index; IFI = Incremental Fit Index; TLI = Tucker-Lewis Index; CFI = Comparative Fit Index

To assess the mediating paths, the Sobel (1988) test was used. Results from this test supported the mediating role of resilience between collective positive emotions and team inrole performance, $\mathrm{Z}=2.58, p<.01$, as well as between collective positive emotions and team extra-role performance, $\mathrm{Z}=3.00, p<.01$. Moreover, a second competitive model (M2) was developed, where the direct effects from positive emotions to in- and extra-role performance were also tested. Model 2 fitted as well as M1, but the chi-squared comparison showed that M2 did not provide significantly better fit (see Table 4.2), $\Delta \chi^{2}{ }_{\text {M1-M2 }}(2)=4.03$, $n s$. These findings suggest a full mediation effect of team resilience between collective positive emotions and team in-role and extra-role performance. As a consequence, Model 1, which is represented graphically in Figure 4.1, was the best-fitting model.

It is interesting to note that in our final model, positive emotions explain $50.8 \%$ of the variance of team resilience $\left(\mathrm{R}^{2}=.508\right)$, which in turn explains $4.2 \%$ of the variance of in-role performance $\left(\mathrm{R}^{2}=.042\right)$ and $6.3 \%$ of the variance of extra-role performance $\left(\mathrm{R}^{2}=.063\right)$. 
Figure 4.1. The final model with standardized path coefficients $(N=216)$

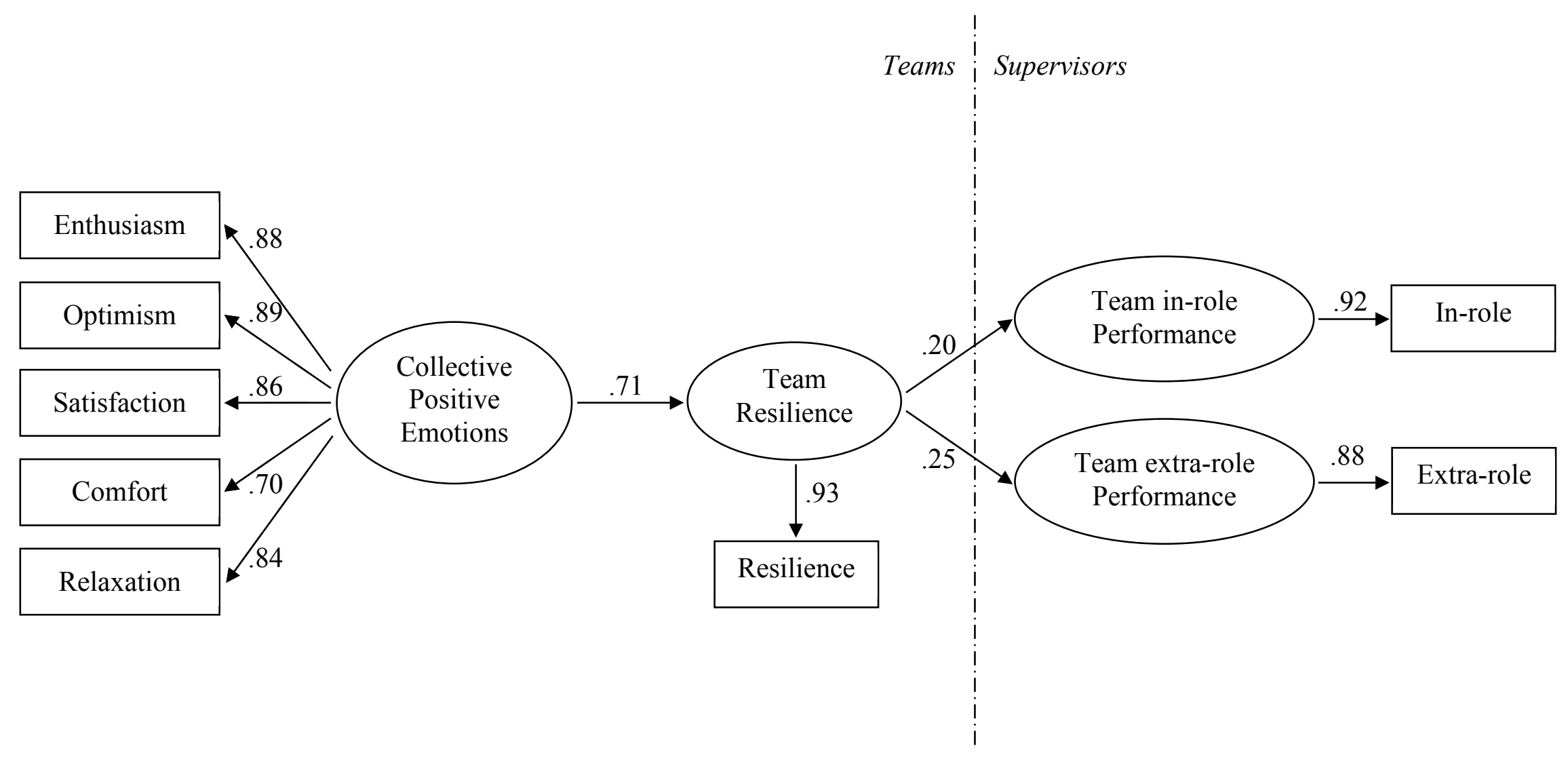


Analyses were repeated controlling all the variables for team size, and all substantive significant effects remained significant (details available on request from the authors).

\section{Discussion}

This paper contributes to the literature on positive emotions by examining the processes (i.e., team resilience) underlying the relationships between collective positive emotions and team performance. To conduct our study we relied on the B\&B theory (Fredrickson, 1998; 2001), which maintains that when people experience positive emotions, they broaden their thought-action repertoires and build resources, such as resilience, that enable them to cope and manage things effectively. Thus, and conceptualized at a collective level, the development of resilience enhanced by experiences of collective positive emotions is a fundamental psychosocial process through which a team's optimal performance can be understood. The results supported our hypotheses, indicating that collective positive emotions (i.e., enthusiasm, optimism, satisfaction, comfort, and relaxation) were positively related to team resilience (confirming Hypothesis 1), and that team resilience was positively related to team inand extra-role performance (confirming Hypothesis 2). Moreover, our study demonstrated significant mediation paths through resilience. Specifically, it was revealed that team resilience fully mediates the effects of collective positive emotions on team performance (confirming Hypothesis 3).

\section{Theoretical contributions}

The findings from the study provide evidence that team resilience fully accounts for the relationship between collective positive emotions and team performance. We extend prior research on positive emotions in the workplace by moving beyond an individual depiction of this phenomenon and its consequences to explore the process that is generated from group members' shared positive emotions. Furthermore, we contribute to the emerging field of Positive Organizational Behavior by revealing how positive emotions are disseminated among work group members and by outlining the positive outcomes that such a process generates.

Firstly, this suggests that experiences of collective positive emotions are particularly useful for building team resilience. This finding is in accordance with the results found at the employee level (Algoe \& Fredrickson, 2011; Cohn et al., 2009; Fredrickson \& Joiner, 2002; Ong et al., 2006; Tugade \& Fredrickson, 2004), and also extend them. In fact, it was shown that through a mechanism of affective sharing (i.e., 
emotional contagion and comparison, and empathy) people easily shared positive emotional experiences and attained a collective positive emotional state (Walter \& Bruch, 2008). Our argument is that, as proposed by the B\&B Theory at the individual level, collective positive emotions allow teams to broaden the scope of both thinking and action, as well as to reinterpret stressful situations and develop positive meaning amidst adversity. This result is in line with previous studies which gave evidence that, when team members share emotion, they are more likely to be motivated and engaged in the process of facing the challenge (Edmondson, Bohmer, \& Pisano, 2001). Thus, the first finding helps to shed light on the processes underlying the relationships between collective positive emotions and team resilience, thereby providing support for the premises of the B\&B theory, and expanding it to the team level of analysis.

Secondly, the present study also suggests that, in the work context and at a collective level, the main process assumed by B\&B theory leads to positive team outcomes, like performance. Accordingly, collective positive emotions shared within the team context support good team performance through the development of resilience. This result highlights the fact that experiences of collective positive emotions do not directly account for behavioral outcomes, which contrasts slightly with the proposal of "happy-productive workers". However, team resilience is illustrated as the fundamental process that links emotional states and behavioral outcomes. This suggests that teams that are surrounded by collective positive emotions are more likely to experience a greater ability to cope with setbacks and obstacles encountered in the work context, which in turn allow them overcome adversity and maintain or enhance positive outcomes. Notably, our results revealed that resilience developed by experiences of collective positive emotions support both in-role and extra-role performance, with a slight additional variance explained by the extra-role measure. This result is in line with the proposal that the specific characteristics of the positive psychological capital namely: efficacy, hope, optimism, and resilience - lead to more frequent engagement in extra-role behaviors (Avey et al., 2010).

\section{Implications for practice}

The results of this study suggest a promising direction for interventions to increase team resilience and improve performance in the work context. In fact, both of these aspects have been associated with the presence of collective positive emotions, 
and thus HRM has the opportunity to shape them by proactively influencing the affective state within their teams.

We suggest that it would be useful to provide individuals with ample opportunities to exhibit their positive emotion within the team context. Group members should therefore be able to easily recognize each other's positive affective expressions on a conscious or non-conscious basis, thereby facilitating processes of emotional contagion, emotional comparison, and empathy (Bartel \& Saavedra, 2000). Moreover, it was shown that high-quality group relationships should strengthen affective sharing over time, and consequently team members may display a stronger tendency to develop homogenous positive moods and emotions (Walter \& Bruch, 2008). In this sense, creating and maintaining group bonds, establishing close ties between group members, and enhancing group processes and relationship quality are crucial for HRM.

We also proposed that HRM can try to elicit positive emotions by consistently reminding people to think positively and to find a positive meaning when negative events occur (Luthans et al., 2006). Though organizational members may have been trained to do this, they will still look to their leaders for reassurance or reminders to think positively during times of adversity (Fredrickson, 2001), in order to make more constructive interpretations, develop an intelligent optimism as well as tolerance to frustration. In this sense, managers' leadership behavior could constitute a powerful resource, and development of transformational leadership seems crucial (Moss, Dowling, \& Callanan, 2009).

HRM strategies could also be used to proactively build positive emotional experiences for organizational members. For instance, an organization that allows its employees to gain meaning and satisfaction from their work may be providing another vehicle in which positive feelings can be created around ordinary events (Coutu, 2002). Furthermore, training emotional intelligence at work (both individually and collectively) could be an interesting area of intervention to increase levels of positive emotions (Salanova, Llorens, \& Schaufeli, 2011).

\section{Limitations and research directions}

Some limitations of our study should be noted. One limitation is the use of selfreports for the first part of our hypothesized model, since this implies a risk of common method variance. However, our findings were in line with theoretical predictions and with earlier findings, while Harman's one-factor test suggests that common method 
variance should not be a serious threat in our study. Moreover, the use of supervisor ratings of performance is a strong point of this study that adds to the robustness of our findings.

Another limitation of the present study is that data are cross-sectional. Although SEM analysis gives some information about the possible direction of the relationships, cross-sectional study designs do not allow to draw firm conclusions regarding the causal ordering among the variables studied. Thus, longitudinal research is encouraged to examine the causal relationships between collective positive emotions, team resilience, and team performance. For instance, previous data at the individual level revealed clear evidence for an upward spiral in the sense that individuals who experienced more positive emotions than others became more resilient to adversity over time and, in turn, these enhanced coping skills predicted increased positive emotions over time (Fredrickson \& Joiner, 2002). Accordingly, future research is needed to investigate the dynamic interplay of collective positive emotions and team resilience in the form of a self-reinforcing spiral. Reasonably, this spiraling process will manifest in a continuous upward movement toward greater collective positive emotions and toward increasing team resilience within work groups over time.

A final limitation concerns the restricted set of collective emotions and outcomes measured. Although the emotions selected are representative of the main category of the most widely used taxonomy (Warr, 1990), taking into account a greater number of emotions would make it possible to investigate whether there is a category (or combination of categories) that provides a greater explanation of the development of resilience. For instance, the recent debate about the utility of discrete emotions calls for more attention to be paid to the role they have in predicting different outcomes across particular organizational contexts (Lindebaum \& Jordan, 2012). Regarding the outcomes measured, we focused on just two indicators of performance but, for example, Whitman, Van Rooy, \& Viswesvaran (2010) argued that results-oriented criteria like customer satisfaction and productivity should also be the focus of organizational research.

\section{Concluding remarks}

The findings of this study offer important implications and provide support for the B\&B theory of positive emotions as an effective theoretical framework to explain how collective positive emotions influence team resilience in the work context. In addition, 
the results show the existence of a positive relationship between team resilience and performance, both in- and extra-role, while also offering evidence of the importance of positive emotions and resilience in order to improve performance. Furthermore, this study makes an interesting contribution to the resilience literature by providing evidence for its applicability at the team level within the organizational context. 


\title{
CHAPTER 5
}

\section{How to promote Academic Satisfaction and Performance: Building Academic Resilience through Coping Strategies ${ }^{4}$}

\begin{abstract}
Academic resilience refers to the interactive processes that enable students to succeed despite unfavorable circumstances. The aim of this article is twofold: (1) to validate the psychometric properties of the Academic Resilience Scale (AR-S) in a Spanish university context by examining its construct validity and reliability, and its convergent and divergent validity; and (2) to test a model where different coping strategies are antecedents of academic resilience, and academic satisfaction and performance (GPA) are its consequences. The studies were conducted among 185 (study 1) and 780 (study 2) students, and data about academic performance were collected after a period of $4 / 5$ months. The results confirmed the good psychometric properties of the AR-S in the Spanish context, giving evidence for its validity. Furthermore, the distinctive role of different coping strategies in resilience was confirmed, as well as the relationship between resilience and academic satisfaction. Contrary to expectations, no direct relationship between resilience and performance was found, highlighting the full mediation role of satisfaction. Implications for theory and practice, as well as limitations and avenues for future research are discussed.
\end{abstract}

Key words: Academic Resilience, Coping strategies, Academic Satisfaction, GPA, Scale Validation, Path Analysis

${ }^{4}$ Chapter 5 has been submitted for publication as: Meneghel, I., Martínez, I. M., Salanova, M., \& De Witte, H. How to promote Academic Satisfaction and Performance: Building Academic Resilience through Coping Strategies. School Psychology Quarterly. 


\section{Introduction}

In view of an increasing need for healthy and competent workers that can cope with the current dynamic and changing work context, it is crucial to educate and motivate university students in order to provide individuals who will be valuable and educated contributors to the economy and the nation in the long run (Riolli, Savicki, \& Richards, 2012). Recent research has shown that psychological distress among university students is significantly higher than among the general population (Adlaf, Gliksman, Demers, \& Newton-Taylor, 2001; Stallman, 2010) and it has also been established that stress increases as students progress in their studies (Putwain, 2007). Indeed, university students confront many challenges in the pursuit of their educational goals, ranging from the demands of their academic course work to challenges in managing intrapersonal and interpersonal changes (Houghton, Wu, Jeffrey, Christopher, \& Charles, 2012; Ross, Niebling, \& Heckert, 1999). Some studies suggest that exams are the most important sources of stress for students (Roddenberry \& Renk, 2010), probably because students are often under high pressure to earn good grades and to obtain a degree or other qualification (Hirsch \& Ellis, 1996). Furthermore, they are involved in structured coercive activities, such as doing assignments and attending classes that may also be sources of academic stress (Salanova, Schaufeli, Martínez, \& Bresó, 2010).

The impact of stressors on student well-being can have a variety of negative psychological, health, and behavioral effects that cause high levels of distress and may reduce students' performance. For instance, academic stress has been associated with disorders such as depression (Dao, Lee, \& Chang, 2007), school failure (McDonald, 2001), poor academic performance (Zeidner, 1998), study burnout (Salanova et al., 2010), and disturbances in the immune system (Vedhara \& Nott, 1996). However, some students have the capacity to successfully withstand the consequences of negative academic experiences. They are easily encouraged following minor setbacks and generally view negative challenging events as surmountable (e.g., Perry \& Magnusson, 1989; Struthers \& Perry, 1996). Nevertheless, little is known about the relative strength of the effects of various factors that promote positive adaptation in the face of academic stress (Leary \& DeRosier, 2012).

The concept of resilience might help to explain why some individuals who experience high levels of stress are able to withstand it and may even thrive on it, 
thereby enabling them to manage future challenges more effectively (Grant \& Kinman, 2012). Developing resilience is therefore essential in the process of stress management of university students. Thus, to account for the discrepancy in students' responses to negative threatening events, the present study focused on academic resilience as the factor that promotes positive adaptation and outcomes during the academic stage.

From a stress-coping perspective, numerous studies have highlighted the importance of coping when dealing with adversity (e.g., Clauss-Ehlers, 2008; Leipold \& Greve, 2009; Sinclair \& Wallston, 2004; Tugade \& Fredrickson, 2004) and individuals use a range of coping strategies to deal with that. Therefore, in academic-related stressful situations, students may have different ways to face it, that is, they possess different coping strategies, the results of which will differ in their effects on well-being and performance. In this study we investigated the predicting role of distinct coping strategies on academic resilience. Moreover, we examine whether the relationship between coping strategies and academic resilience stimulated positive academic outcomes, assessed by two widely recognized indicators, namely, academic satisfaction and performance. In sum the present study aims to further our understanding about how coping strategies drive the individual experience to promote favorable reactions (i.e., resilience) in order to obtain more satisfaction and better performance.

The strengths of this study are based on the extension of previous research in this field in several ways. First, although earlier studies have already examined coping strategies as predictors of resilience, they mainly combine scales into general problemand emotion-focused categories of coping. Instead, as suggested by Carver, Scheier, and Weintraub (1989), we use the data to determine the composition of the higher-order factors because different samples exhibit different patterns of relations, and thus we create second-order factors from among the subscales. Second, we include the Grade Point Average (GPA) provided by the University as an objective measure of academic performance in order to have an objective evaluation of this variable and better control for method bias, thus strengthening the validity of our results. Moreover, we use a longitudinal design and measure objective academic performance after administration of the questionnaires with the psychosocial variables, which was performed 4 or 5 months later. Finally, we use a sample of students pursuing different degree courses at different faculties in order to reinforce the generalizability of the results. 


\section{About the concept and measure of Academic Resilience}

Positive psychology has embraced resilience as a prime example of what is right and good about people (Luthans, Vogelgesang, \& Lester, 2006). In this field, it has been argued that focusing on salutogenic (or health-enhancing) rather than pathogenic (or disease-reducing) factors will be more successful in promoting well-being in various life contexts (Seligman, 2003). In accordance with this framework, in this study we focused on resilience, since it refers to the process of positive adaptation in the face of significant stress or adversity (Luthar, Cicchetti, \& Becker, 2000). Applied to the academic context, resilience research focuses on the mechanisms and the interactive processes that enable students to succeed despite unfavorable circumstances (Doll \& Lyon, 1998).

We refer to academic resilience as the process of dealing with academic adversity and achieving positive outcomes in stressful situations. A substantial body of evidence reports that academically resilient students are those who sustain high levels of achievement, motivation and performance despite the presence of stressful events and conditions (Alva, 1991; Leary \& De Rosier, 2012). To date, the few studies that have dealt with academic resilience are focused on ethnic-minority groups, learning difficulties, and extreme underachievers. However, academic resilience is relevant to all students because at some point all of them may experience adversity, challenge, or pressure during their academic life (Martin \& Marsh, 2006). Consequently, we propose that the study of academic resilience can help further our understanding of the process through which students are able to successfully adapt to, or "bounce back" from, stressing or negative situations. That is, the study of academic resilience has the potential to enhance our understanding of students' positive adaptation and outcomes, as well as providing insight into possible interventions (Steinhardt \& Dolbier, 2008).

Regarding the measurement of academic resilience, it is interesting to notice that over the last few years different instruments have been used to measure resilience in student populations; however, in most cases they are not specific for the academic context (e.g., Campbell-Sills, Cohan, \& Stein, 2006; Dolbier, Jaggars, \& Steinhardt, 2010). To our knowledge the scale proposed by Martin and Marsh (2006) is the only one that: (a) focuses specifically on academic resilience, and (b) has a different content from previous measures, which have generally assessed protective factors or resources 
involving personal characteristics and coping styles (e.g., Connor \& Davidson, 2003; Wagnild \& Young, 1993), and framed items as statements referring to the process of bouncing back, resisting illness, adapting to stress, or thriving in the face of academic adversity. Thus, we aim to evaluate the psychometric characteristics of the Spanish version of the academic resilience scale of Martin and Marsh (2006) in the first study in this paper (see study 1 in the method and results sections for more details).

Thus, we predict the following:

Hypothesis 1. The Spanish version of the AR-S will demonstrate acceptable psychometric properties (i.e., construct validity, reliability, convergent and divergent validity).

\section{Coping strategies as antecedents of Academic Resilience}

To understand people who face adversity, it is undoubtedly important to identify the characteristics or factors that may promote resilience, such as coping strategies (Smith et al., 2008; Steinhardt \& Dolbier, 2008), for example. Coping has been defined as a person's efforts to remove, reduce, or manage threatening events or situations that are appraised as challenging or stressful (Lazarus \& Folkman, 1984). Although resilience and coping are sometimes used interchangeably, they are in fact related but conceptually distinct constructs. Whereas coping refers to the set of cognitive and behavioral strategies used by an individual to manage the demands of stressful situations, resilience refers to adaptive outcomes in the face of adversity (CampbellSills et al., 2006).

Researchers have generally clustered coping responses into theoretically derived factors. One of the earlier nomenclatures, proposed by Folkman and Lazarus (1980), distinguishes two major functions of coping: problem-focused coping and emotionfocused coping. Problem-focused coping involves addressing the problem causing distress. Effective problem-focused coping probably contributes to positive psychological states by allowing people to experience some personal control and sense of accomplishment. Emotion-focused coping is aimed at regulating distress and negative emotion rather than at changing the events themselves, through the use of strategies such as escape-avoidance or support seeking. These strategies involve thoughts and/or actions that relieve or lessen the emotional impact of stress. Research has found that people who cope with stress by seeking social support or venting feelings (emotion-focused) experience more negative outcomes than do people who 
address the experienced stressor directly by working on solving their problems (problem-focused) (Suldo, Shaunessy, Michalowski, \& Shaffer, 2008). Previous results about coping strategies and resilience also confirmed these results (Campbell-Sills et al., 2006).

Research found that the problem-focused and emotion-focused distinction was a good starting point, but they identified meaning-focused coping as a different type of coping in which cognitive strategies are used to manage the meaning of a situation (Folkman \& Moskowitz, 2004). Meaning-focused coping is substantially aimed at regulating positive emotions. There is substantial evidence suggesting that positive emotions occur alongside negative emotions throughout intensely stressful periods and are of great significance for adaptation (Folkman, 2008). The Broaden and Build Theory of positive emotions (Fredrickson, 1998; 2001) shows that positive emotions broaden the individual's focus of attention and behavioral repertoire, thereby replenishing his or her social, intellectual, and physical resources. Therefore, positive emotions need to be included to learn more about how people generate and sustain them and to further explore their adaptation significance in relation to outcomes.

In accordance with these three different kinds of coping categories, we postulate distinct hypotheses about the relation between coping strategies and resilience. First, we propose that students that show high levels of active coping and use problem-focused strategies are more resilient. Thus, we expect:

Hypothesis 2. Problem-focused coping will be positively related with academic resilience.

Second, we suggest that students using emotion-focused strategies, which are aimed at regulating distress and negative emotions, reduce their efforts in dealing with the problem and thus are less resilient. Hence, we expect:

Hypothesis 3. Emotion-focused coping will be negatively related with academic resilience.

Finally, we propose that students who regulate positive emotions by attributing meaning to the situation broaden their thought-action repertoires and build resources that enable them to cope and manage things effectively, like resilience. Thus, we expect that:

Hypothesis 4. Meaning-focused coping will be positively related with academic resilience. 


\section{Consequences of Academic Resilience (satisfaction and performance)}

In studying the consequences of academic resilience, we focused on academic satisfaction and academic performance. In this study, academic satisfaction is considered as students' cognitive evaluations of various aspects of their academic context (i.e., teachers, degree, and faculty). Academic satisfaction was considered as the subjective intrinsic gratification students experience through their educational pursuits (Ryan, 2001), and its importance as an indicator of school adjustment (Baker, Dilly, Aupperlee, \& Patil, 2003) as well as of quality in higher education (Byrne \& Flood, 2003) is recognized. On the grounds that academic resilience is useful in helping students to overcome the stress and adverse situations they have to face in the academic context, we propose that, when students show a high level of resilience, they will naturally experience higher satisfaction with the aspects of their academic context. Indeed, students with higher levels of resilience, even when they experience stressful and adverse events in their academic context, are expected to positively adapt to and successfully bounce back from these events (Finn \& Rock, 1997; Leary \& DeRosier, 2012). Therefore, we postulated that this positive response enhances their academic satisfaction. This relationship is well established in the work context (Larson \& Luthans, 2006; Youssef \& Luthans, 2007). However, to our knowledge it is not fully recognized in the academic one. Therefore, we formulate the following hypothesis:

Hypothesis 5. Academic resilience will be positively related with academic satisfaction.

In accordance with the evidence showing that attitudes are proximal antecedents and guidelines of behavior (Ajzen \& Fishbein, 2005), we propose that the more students are satisfied with their academic context, the more likely they are to engage in positive behaviors, thus performing better. It was long assumed that a cognitive attitude (i.e., satisfaction) is the primary source of student performance (Rode et al., 2005). Previous studies corroborated this relationship; for instance Chambel and Curral (2005) showed that satisfaction among Portuguese students had a direct and positive impact on their performance. Research involving high school students in Australia has also shown that academic satisfaction is positively related to academic achievement and negatively related to disengagement and dropping out of school (Ainley, Foreman, \& Sheret, 
1991). In order to test our last hypothesis, we take into consideration the students' GPA, which provides a more objective measure of students' academic performance. Thus, we expect the following:

Hypothesis 6. Academic satisfaction will be positively related with academic performance (GPA).

Previous research has suggested that resilience leads to an increase in performance (Luthar, 1991), because it better prepares individuals to rebound or bounce back from adversities, problems, and failures since they are more flexible to changing demands, open to new experiences, and they tend to use setbacks as "springboards" or opportunities for growth (Tugade \& Fredrickson, 2004). In line with this assumption, previous studies have found academic resilience to be connected to academic performance (Kwok, Hughes, \& Wen, 2007; Scales, Roehlkepartain, Neal, Kielsmeier, $\&$ Benson, 2006). Thus, building on our earlier explanation of the relationships between resilience and satisfaction on the one hand, and the relationships between satisfaction and performance on the other, we expect resilience to influence academic performance through satisfaction. Specifically, we predict that, when resilience is high, students will also perform better because they experience more academic satisfaction engendered by resilience. Hence, we argue that academic satisfaction is a partial mediator of the effects of academic resilience upon academic performance. Therefore, we formulate the following hypothesis:

Hypothesis 7. Academic satisfaction will partially mediate the relationship between academic resilience and academic performance (GPA).

\section{STUDY 1}

The first study assessed the psychometric properties of a Spanish adaptation of the academic resilience scale developed by Martin and Marsh (2006). We conducted a number of tests in order to determine the validity and reliability of the measure. First, a confirmatory factor analysis was carried out and construct validity was tested. Subsequently, the reliability of the academic resilience scale was investigated, together with its convergent and divergent validity.

\section{Method}

\section{Sample and procedures}

The first study involved 185 students from a Spanish university. The sample size fits all the criteria suggested by Muthén and Muthén (2002) for determining sample size 
through a Monte Carlo study: a) parameter and standard error biases did not exceed $10 \%$ for any parameter in the model; b) the standard error bias for parameters that are the specific focus of the power analysis (e.g., the factor covariance of resilience and self-efficacy) did not exceed 5\%; and c) coverage, that is, the confidence intervals, was between .91 and .98. In addition to these criteria, appropriate sample size was determined because the power of the salient model parameters was above .80 (detailed values are available upon request).

Each student received a brief presentation of the study by the researchers during class time and was invited to individually fill out a paper and pencil questionnaire on academic well-being. Participants (57.5\% females) were stratified and belonged to the four faculties of the University, that is: Faculty of Humanities and Social Sciences (56.5\%), School of Technology and Experimental Sciences (17.4\%), Faculty of Health Sciences (14.7\%), and Faculty of Law and Economics (11.4\%). Ages ranged from 18 to 44 years $(M=22.8 ; \mathrm{SD}=5.06$ years $)$. Most of them $(95.6 \%)$ were doing a bachelor's degree lasting four years, whereas the others were doing five-year degrees from the previous curriculum (4.4\%). Regarding the course they were doing, $13.7 \%$ were in the first year, $50.5 \%$ in the second, $27.5 \%$ in the third, $7.1 \%$ in the fourth, and $1.1 \%$ were in their fifth year. Eighty percent of them were not working at that moment.

\section{Measures}

All the items of measures used were scored on a 7-point scale ranging from 0 (completely disagree) to 6 (completely agree).

\section{The Academic Resilience Scale}

The Spanish version of the Academic Resilience Scale (AR-S) was a translation of the Martin and Marsh (2006) scale. The translation was performed by two researchers, who were fluent in Spanish and English, and then two other researchers were asked to compare the Spanish and the English versions of the scale. The construct was measured with a six-item scale. An example item is: "I think I'm good at dealing with schoolwork pressures".

\section{Other measures}

A number of existing measures were used in this study in order to assess the convergent, divergent and construct validity of the academic resilience scale.

Resilience. Another measure of resilience was assessed with the short 12-item version of the Psychological Capital Questionnaire (PCQ-12, see Luthans, Avey, Smith, 
\& $\mathrm{Li}, 2008)$ adapted to the academic context. In this instrument, resilience was measured with a three-item scale. An example item is: "I usually take stressful things in my stride with regard to my studies". Cronbach's alpha was .60.

Self-efficacy. Self-efficacy was measured with a five-item scale developed by Midgley and colleagues (2000) and used with a sample of Spanish students (Salanova, Bresó, \& Schaufeli, 2005). An example item is: "I can do even the hardest work in this class if I try". Cronbach's alpha was .74.

Proving Goal Orientation. Proving goal orientation was assessed with a four-item scale from the Goal Orientation scale developed by VandeWalle (1997). An example item is: "It's important for me to prove that I am better than others in class". Cronbach's alpha was .75.

\section{Results}

\section{Construct validity}

With the purpose of confirming the one-factor structure of the AR-S and its relatedness to other constructs, we performed a confirmatory factor analysis including a theoretically relevant concept, that is to say, self-efficacy. From a theoretical point of view, self-efficacy has been advanced as an important supportive characteristic of academic resilience. Bandura (2011) suggested that people high in self-efficacy view impediments as surmountable by developing requited competencies and making a perseverant effort, and thus they are able to face difficulties and remain resilient to adversity. In this way, it is proposed that students' beliefs about themselves and their academic capacities influence their behaviors and emotional reactions, thereby allowing them to perform successfully in the face of obstacles or adverse experiences.

In order to shed more light on the relationship between these variables, structural equation modeling (SEM) was used to test the fit of the structural models. The analysis was performed using AMOS 21.0 and a number of fit indices were used to assess the model fit. Goodness of fit can be determined with the following indices (Hu \& Bentler, 1999): chi-square test $(\chi 2)$; Comparative Fit Index (CFI $\geq .90)$; the Normed Fit Index $(\mathrm{NFI} \geq .90)$; the Tucker-Lewis Index (TLI $\geq .90)$; and Root-Mean-Square Errors of Approximation $($ RMSEA $\leq .08)$. SEM results were used to compare a single-factor model (that tested all items of resilience and self-efficacy loading on one factor) with a two-factor model (that tested all items loading on two different factors) to determine which models fit better. Confirmatory factor analyses (CFA) conducted on the single- 
factor model revealed inadequate fit indices $\left(\chi^{2}(44)=248.59, \mathrm{CFI}=.76\right.$, NFI $=.73$, $\mathrm{TLI}=.64, \mathrm{RMSEA}=.16)$, whereas the two-factor model fits the data well $\left(\chi^{2}(43)=\right.$ $90.03, \mathrm{CFI}=.95, \mathrm{NFI}=.90, \mathrm{TLI}=.92, \mathrm{RMSEA}=.08)$. The comparison of chi-square statistics indicated that the two-factor model fits the data significantly better than did the one-factor model $\left(\Delta \chi^{2}(1)=158.56, p<.001\right)$. All items had significant loadings on their intended latent factor. Moreover, as expected, self-efficacy related positively and significantly to academic resilience: $\beta=.37, p<.001$. Based on these findings, we can empirically confirm the factor structure of the resilience measure and also that selfefficacy relates significantly to academic resilience, but they are conceptualized in different ways, thus providing empirical support for the construct validity of AR-S.

\section{Reliability}

An important step in establishing the psychometric characteristics of a scale is to determine its reliability. We used Cronbach's alpha as a measure of the internal consistency reliability of the scale, because it reflects the extent to which the items are homogeneous. The AR-S showed excellent reliability with a value for Cronbach's $\alpha=$ .90 (Kline, 2011).

\section{Convergent validity}

Convergent validity of the scale was checked in two ways. Firstly, we inspected whether our measures of academic resilience were related with another (criterion) resilience measure. The convergent validity of the AR-S was examined by correlating it with the resilience scale from the PCQ-12, adapted to the academic context (Luthans, Avey, Smith, \& Li, 2008; Luthans, Youssef, Sweetman, \& Harms, 2013). Convergent validity is assumed when the scales of the tested instrument correlate both positively and moderately to highly with the criterion instrument (Kline, 2011). Pearson's correlation coefficient between the AR scale and the resilience scale from the PCQ-12 was computed, and the results showed that it was high and significant $(\mathrm{r}=.58, p<.01)$.

We then computed the average variance extracted (AVE; Fornell \& Larcker, 1981) to examine the convergent validity of the AR-S in more detail. The AVE represents the extent to which items of a specific construct "converge" or share a high proportion of variance in common. A model can be considered to have good convergent validity if at least $50 \%$ of the measurement variance is captured by the construct $(A V E>.50)$. The estimated AVE of the AR-S is .61. Taken together, results support the convergent validity of the AR-S. 


\section{Divergent validity}

Finally, the divergent validity was checked by demonstrating that academic resilience is different from another (criterion) variable. We investigated the divergent validity of the AR-S by correlating it with the proving dimension of goal orientation. A proving goal orientation is a focus on demonstrating one's competence and the gaining of favorable judgments or positive evaluations from others (VandeWalle, Cron, \& Slocum, 2001). Previous evidence showed that proving goal-oriented students typically do not increase their efforts following failures and, when confronted with obstacles, they exhibit decreased problem-solving, and readily disengage from goals even if they were performing adequately previously (Snyder et al., 2002). Thus, they are not expected to develop resilience when faced with an adverse situation, which was an important reason for us to choose this measure to examine the divergent validity of our scale.

Divergent validity is assumed when the scales of the tested instrument show a low-to-moderate correlation with the criterion instrument (Kline, 2011). Pearson's correlation coefficient between the AR-S and the proving goal orientation scale was computed and the results showed that the correlations were low and not significant $(\mathrm{r}=-.01, p=.95)$. These results provide evidence for a good divergent validity of the AR-S.

\section{STUDY 2}

In order to explore the hypothesized theoretical model and verify Hypotheses 2 to 6 , the second study was carried out in a different and larger sample of university students. To test our hypotheses, several analyses were carried out and the model was tested using SEM.

\section{Method}

\section{Sample and procedures}

The second study involved 780 students from a Spanish university. Each student was given a brief presentation of the study by the researchers during class time and was invited to individually fill out a paper and pencil questionnaire on academic well-being. Participants (59.7\% females) were stratified and belonged to the four faculties of the University, namely: Faculty of Humanities and Social Sciences (33.2\%), School of Technology and Experimental Sciences (25\%), Faculty of Law and Economics (24.5\%), 
and Faculty of Health Sciences (17.3\%). Ages ranged from 18 to 61 years $(M=22.7$; $\mathrm{SD}=5.68$ years). Most of them (93.4\%) were doing a bachelor's degree lasting four years, whereas the others were doing five-year degrees from the previous curriculum (6.6\%). Regarding the year they were studying, $35.7 \%$ were in the first year, $37.2 \%$ were in the second, $19.6 \%$ were in the third, $6.5 \%$ were in the fourth, and $9 \%$ were in their fifth year. The $84.1 \%$ of them were not working at that time.

\section{Measures}

The students completed the AR-S described in Study 1 to assess their level of resilience. Moreover, three other measures were used in this study in order to test our hypotheses.

Coping strategies. The Spanish version of the Brief COPE inventory was used to assess coping strategies (Perczek, Carver, Price, \& Pozo-Kaderman, 2000). It includes 14 two-item subscales: active coping, acceptance, emotional support, instrumental support, positive reframing, planning, self-distraction, denial, behavioral disengagement, venting, self-blame, religion, humor, and substance use. An example item is: "In the presence of difficult situations related to my studies, I've been taking action to try to make the situation better" (active coping subscale). For each of the items, respondents indicated the extent to which they used the strategy in dealing with stressful situations on a 4-point Likert scale ranging from 0 (not at all) to 3 (a lot). Cronbach's alphas ranged between .62 and $.94($ mean $=.77)$.

Academic Satisfaction. Academic satisfaction was measured with a three-item scale that takes into consideration three salient aspects for university students: their professors, the degree that they are studying for, and the faculty to which they belong. An example item is: "How satisfied are you with your professors?" and students indicated the extent of their satisfaction on a 5-point Face scale ranging from 1 (frowning) to 5 (smiling).

Academic success. Future academic success was assessed by using objective performance as reflected by the GPA, provided by the University at the end of the second exam session after the distribution of the questionnaire, which therefore means 4 or 5 months later. In accordance with the Spanish system of qualifications, GPA ranged from 5 (poor) to 10 (excellent).

\section{Fit indices}


Our data were analyzed by means of SEM techniques using the AMOS 21.0 software package (Arbuckle, 2005). The covariance matrix was analyzed using the maximum-likelihood estimation method. To reduce the complexity of the models examined, we used manifest variables for all constructs (Jöreskog \& Sörbom, 1993). To use scores for our coping manifest variables that encapsulate the factor loadings of their underlying subscales, we calculated their weighted factor score. Since academic resilience, satisfaction, and GPA are one-dimensional constructs, we used their standardized scores as manifest variables (Xanthopoulou, Bakker, Demerouti, \& Schaufeli, 2009).

The fit of the models was assessed by computing the absolute and relative goodness-of-fit indices. Specifically, we used the chi-square $\left(\chi^{2}\right)$ statistic, the root mean square error of approximation (RMSEA), as well as the Normed Fit Index (NFI), the Incremental Fit Index (IFI), and the Comparative Fit Index (CFI). For the RMSEA, values up to .08 represent reasonable errors of approximation (Browne \& Cudeck, 1993). For the other statistics, values of .90 or higher were indicative of good fit (Hu \& Bentler, 1999).

\section{Results}

\section{Preliminary analyses}

Before testing our hypotheses, we conducted an exploratory factor analysis (EFA) to examine how the coping subscales grouped together to form broader coping constructs in university students. In fact, the theory proposes that the 14 coping strategies assessed by these subscales are part of several larger constructs (e.g., problem-focused, emotion-focused, meaning-focused); however, researchers have warned against the practice of assuming that certain coping strategies are always grouped in the same way across different contexts (Lazarus \& Folkman, 1984). Therefore, we standardized the total score of each lower-order coping subscale and conducted a principal axis factoring (PAF) analysis with varimax rotation on the 14 coping subscales. The advantage of PAF is that it takes into account the degree to which each lower-order factor contributes to the overall factor (i.e., factor loadings), when calculating factor scores (Xanthopoulou et al., 2009). Subscales with a loading of less than .40 (self-blame, religion, substance use, and self-distraction) were sequentially deleted, which resulted in 10 subscales loading on 4 factors. Factor loadings of the lower-order coping subscales are presented in Table 5.1. 
Factor 1 included the subscales planning and active coping, named problemsolving coping. Factor 2 consisted of the subscales emotional support, instrumental support, and venting, named social coping. Factor 3 consisted of the subscales denial and behavioral disengagement, named avoidant coping. Factor 4 included the subscales positive reframing, humor and acceptance, referred to as positive acceptance coping. All 4 factors accounted for $45.03 \%$ of the total variance explained. In accordance with the coping literature, factor 1 (namely problem-solving coping) is consistent with the problem-focused category, factors 2 and 3 (namely social and avoidant coping) are representative of the emotion-focused category, and factor 4 (namely positive acceptance coping) is coherent with the meaning-focused category.

Table 5.1

Results of principal axis factoring analyses: standardized factor loadings of lowerorder coping strategies on higher-order factors $(N=780)$

\begin{tabular}{|c|c|c|c|c|}
\hline \multirow[b]{2}{*}{ Lower-order coping strategies } & \multicolumn{4}{|c|}{ Higher-order Factors } \\
\hline & $\begin{array}{l}\text { Problem- } \\
\text { solving }\end{array}$ & Social & Avoidance & $\begin{array}{c}\text { Positive } \\
\text { acceptance }\end{array}$ \\
\hline Active coping & .811 & & & \\
\hline Planning & .550 & & & \\
\hline Emotional support & & .873 & & \\
\hline Venting & & .606 & & \\
\hline Instrumental support & & .548 & & \\
\hline Disengagement & & & .655 & \\
\hline Denial & & & .642 & \\
\hline Positive Reframing & & & & .561 \\
\hline Humor & & & & .550 \\
\hline Acceptance & & & & .544 \\
\hline
\end{tabular}


In order to confirm the structure of our coping factors, we also conducted a series of subscale-level CFA. We compared a model where the 14 original subscales from COPE load on one general coping factor (M1) with a model where the final 10 subscales from the EFA load on one general coping factor (M2), and with a model where the final 10 subscales from the EFA load on the respective underlying covariate factors (M3). Results supported the use of 10 subscales of coping against the 14 originally proposed $\left(\Delta \chi_{\mathrm{M} 1-\mathrm{M} 2}^{2}(42)=243.80, \mathrm{p}<.001\right)$, and also their belonging to the four factors $\left(\Delta \chi_{\mathrm{M} 2-\mathrm{M} 3}^{2}(6)=553.28, \mathrm{p}<.001\right)$.

\section{Descriptive analyses}

Table 5.2 presents the correlations among the study variables, as well as Cronbach's $\alpha$ on the diagonal. Given that the variables used are standardized factor scores, means and standard deviations are not reported. Correlations between the 10 separate subscales of coping will be provided by the first author upon request. All correlations were in the expected direction.

Table 5.2

Reliability and correlations for the study variables $(N=780)$

\begin{tabular}{lccccccc}
\hline & 1 & 2 & 3 & 4 & 5 & 6 & 7 \\
\hline 1. Social coping & $. .81)$ & & & & & \\
2. Problem-solving coping & -.06 & $(.68)$ & & & & \\
3. Positive acceptance coping & -.04 & $-.11^{* *}$ & $(.69)$ & & & & \\
4. Avoidance coping & $-.08^{*}$ & $.10^{* *}$ & -.03 & $(.69)$ & & \\
5. Academic resilience & $-.26^{* *}$ & $.16^{* *}$ & $.33 * *$ & $-.14 * *$ & $(.89)$ & \\
6. Academic satisfaction & .01 & $.20^{* *}$ & .01 & $-.08^{*}$ & $.16^{* *}$ & $(.72)$ \\
7. Academic performance & $.12^{* *}$ & $.12^{* *}$ & -.06 & $-.10^{* *}$ & .03 & $.14 * *$ \\
\hline
\end{tabular}

Notes: Cronbach's $\alpha$ reliability estimates are listed in the diagonal in parentheses.

$* p<.05 ; * * p<.01$ 
Although problems with common method bias may have been overstated (Spector, 2006), in order to mitigate the problem we implemented two procedural remedies as suggested in Podsakoff, MacKenzie, and Podsakoff (2012). First, we obtained the measures from different sources, specifically the predictor and mediator measures from students and the criterion measure from an objective source. Second, we differentiated the scale properties shared by the measures of the predictor and mediator variables (for details, see measures section). Finally, the correlations between the study variables were examined, and no significant relationships were found between some of them. When common method bias is present, all of the relationships among variables should be significant; otherwise the common method bias is so small that it is meaningless (Spector, 2006).

\section{Test of hypotheses: path analyses}

Standardized parameter estimates for the hypothesized model are shown in Figure 5.1. As Figure 5.1 shows, social and avoidant coping did negatively and significantly predict resilience $(\beta=-.25, p<.001$, and $\beta=-.17, p<.001$, respectively), whereas problem-solving and positive acceptance coping positively and significantly predicted resilience $(\beta=.20, p<.001$, and $\beta=.34, p<.001$, respectively). Resilience positively and significantly predicted satisfaction $(\beta=.16, p<.001)$, which in turn positively and significantly predicted GPA $(\beta=.14, p<.001)$. No significant relationship was found between resilience and GPA $(\beta=.01, p=.933)$, which suggests full mediation by satisfaction. The results of the SEM analyses in combination with the Sobel test suggest that academic satisfaction fully mediated the relationship between academic resilience and performance $(\mathrm{z}=2.99, p<.01)$. However, our hypothesized model (M1) showed a poor fit to the data: $\chi^{2}(8)=60.85$, RMSEA $=.09, \mathrm{NFI}=.82$, IFI $=.84$, and CFI $=.83$.

The so-called modification indices indicated that the fit of the model could be improved significantly by including direct paths from problem-solving coping to academic satisfaction and GPA, as well as a direct path from social coping to GPA. The results of the SEM analyses showed that the modified model (M2) fits the data reasonably well, $\chi^{2}(6)=16.15, \mathrm{RMSEA}=.05, \mathrm{NFI}=.95, \mathrm{IFI}=.97$, and $\mathrm{CFI}=.97$. Moreover, using the chi-square difference test, M1 and M2 were compared and results supported the modified model against the hypothesized one $\left(\Delta \chi^{2}{ }_{\mathrm{M} 1-\mathrm{M} 2}(3)=44.7\right.$, $p<.001)$. The relationships between the variables are almost invariant between M1 and M2, but the inclusion of these three paths significantly improved the model. Finally, 
Figure 5.1. The hypothesized model with standardized path coefficients $(N=780)$. Dotted lines show non-significant paths.

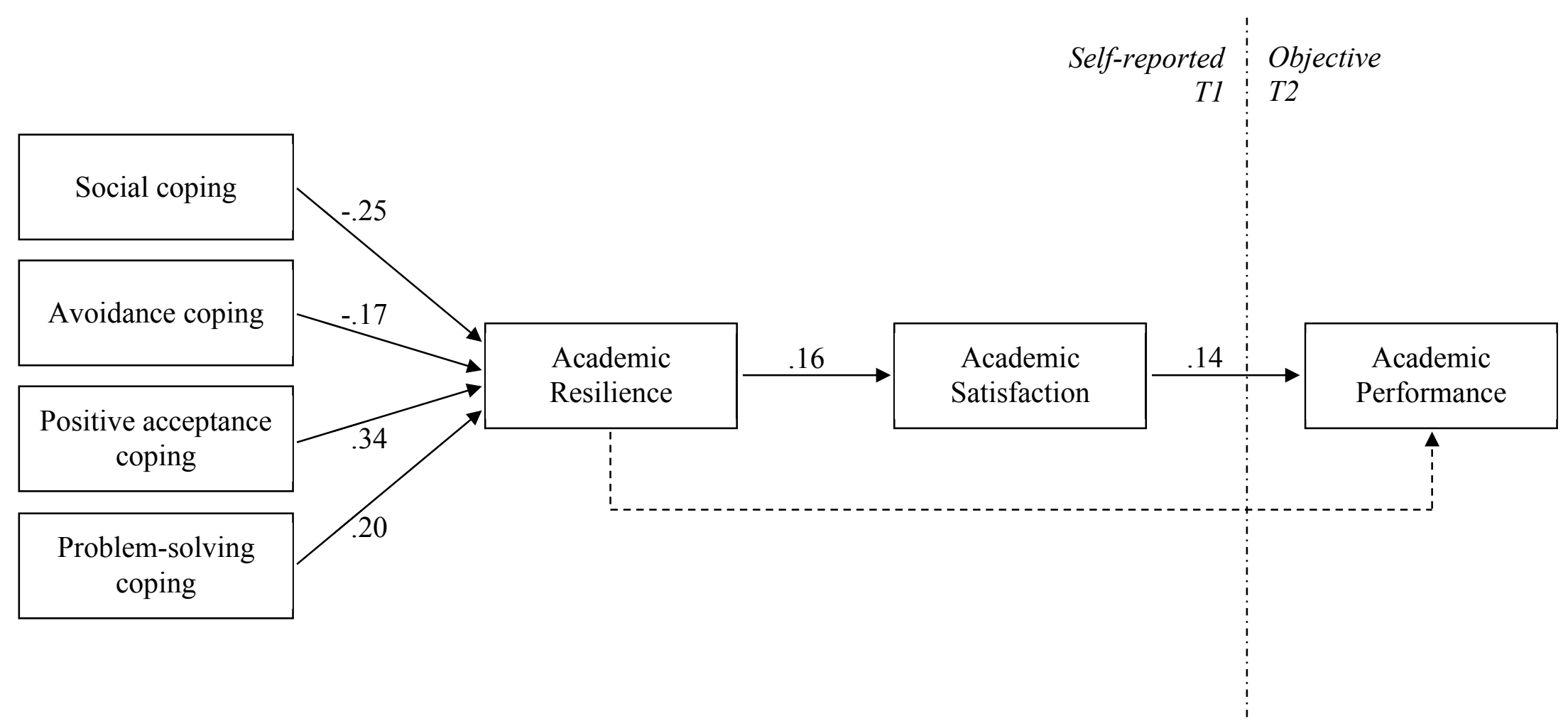


Figure 5.2. The final model with standardized path coefficients $(N=780)$. Dotted lines show non-significant paths

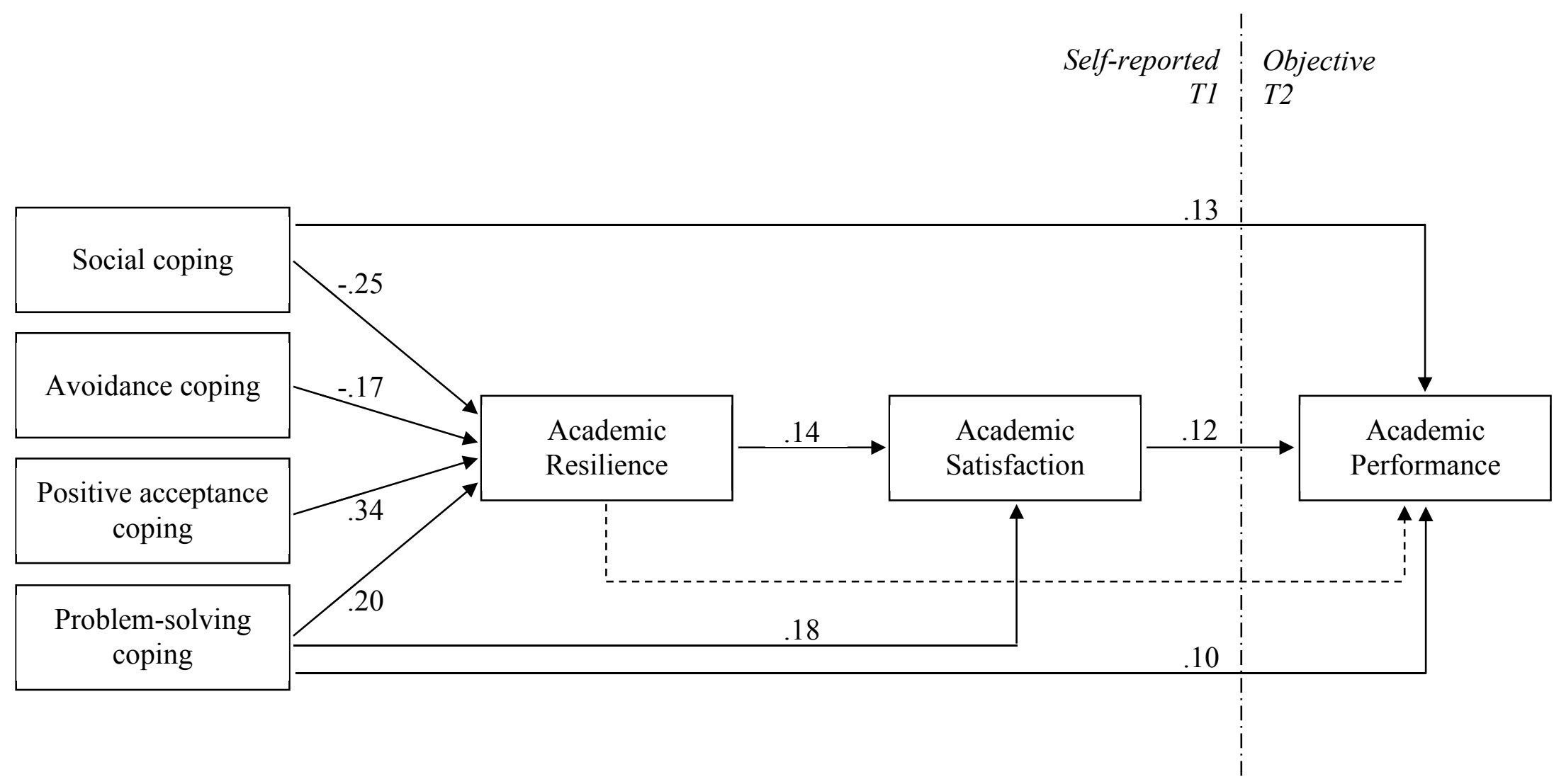


these additional relationships in M2 were positive and significant, thereby showing that problem-solving coping has a direct impact on academic satisfaction and that both problem-solving and social coping have a direct impact on GPA. Figure 5.2 shows the final model, with the standardized coefficients.

\section{Discussion}

The lack of specific tools for measuring resilience in academic contexts in Spain requires the validation of suitable instruments for studying academic resilience. These instruments allow resilience to be evaluated and also enable it to be related to other variables. In this sense, the purpose of the present study was twofold: i) to evaluate the psychometric characteristics of the academic resilience scale of Martin and Marsh (2006) in the Spanish context, checking for its validity and reliability, and ii) to investigate the relationships between coping strategies, academic resilience and academic satisfaction, as well as the impact on academic performance, namely GPA, over time. To achieve these objectives, we conducted two studies. The findings of the first study suggest that the Spanish version of the AR-S demonstrated acceptable psychometric properties (supporting Hypothesis 1). Regarding the second study, the results revealed that students who used emotion-focused coping strategies showed less academic resilience (supporting Hypothesis 3), whereas resilience was higher when problem- and meaning-focused coping strategies were used (supporting Hypotheses 2 and 4). Moreover, students with a high level of academic resilience tended to be more satisfied with their academic context (supporting Hypothesis 5) and students who displayed more satisfaction tended to perform better over time (supporting Hypothesis 6). Furthermore, results indicated that academic resilience was only indirectly related to performance through satisfaction. That is, satisfaction is the pathway through which resilience promotes academic performance (partially supporting Hypothesis 7). Finally, the study revealed three unpredicted significant paths that link coping strategies with outcomes, namely problem-solving coping to both academic satisfaction and performance, and social coping to academic performance.

\section{Theoretical contributions}

The present study represents a step forward with respect to previous research into academic resilience in several ways. Firstly, the validation of the Spanish version of the academic resilience scale from Martin and Marsh (2006) was successful. In order to provide solid evidence for the psychometric characteristics of the scale, we carried out a 
number of analyses rigorously following well-established validation procedures, and we can conclude that the Spanish version of the AR-S demonstrated good psychometric properties. An obvious contribution of the study is the usage of a heterogeneous sample, which consists of Spanish students belonging to four different faculties and several degrees. Hence, the Spanish translation of the AR-S may be used by scholars as a valid scale to investigate resilience in the academic context.

Secondly, by relying on coping strategies as antecedents of academic resilience, we advance theoretical understanding of how different kinds of coping strategies are related with resilience. One strength of the current study is that instead of a priori imposing traditional categorizations (e.g., problem- and emotion-focused coping) on the coping subscales, we factor analyzed the subscales to allow student responses to determine subscale categorization. However, the factors found in this study are strongly supported by previous theoretical conceptualization (Folkman \& Moskowitz, 2004), thus giving support to the validity of our categories. Specifically, we have identified two coping strategies, namely problem-solving and positive acceptance, which enhance resilience. Within the academic context, problem-solving coping should assist students in adjusting to the many challenges posed by the environment, because it involves taking active steps to alter the circumstances or address the problem. Therefore, students who tend to change the situation when they are faced with stressful events have higher levels of resilience. Positive acceptance coping underlies the cognitive strategies used to manage the meaning of a situation and to regulate positive emotions, which is consistent with the emerging attention on meaning-focused coping (Folkman, 2008). In turn, meaning-focused coping is said to generate positive emotions and the underlying appraisals, and these emotions and appraisals influence the resilience process. Therefore, students who tend to generate positive emotions by attributing meaning to the situation should enhance their resilience. In contrast, we have identified two coping strategies, namely social and avoidance coping, which are negatively related with resilience. Both strategies belong to the traditional emotion-focused category and are centered on the regulation of negative emotions, although each of them refers to a definite variety of strategies. Focusing on social coping, students center on looking for social support and venting emotions. Although the strategy can at first help to reduce stress, symptom reduction can be dysfunctional if students mentally focus too much on the situation that created the stress when venting. Therefore, students using more social coping strategies do not develop their resilience. Finally, avoidance is a coping strategy 
occurring when students try to ignore a stressful situation by not thinking about it. Ignoring a stressful situation can be positive in that it may reduce stress, but avoidance involves ignoring the problem, and avoiding the reality of a stressful situation can allow the situation to worsen, thus increasing stress in the long run (Bélanger, Lewis, Kasper, Smith, \& Harrington, 2007). Hence, students who tend to avoid and ignore the problem reduce their resilience.

Thirdly, in studying the outcomes of academic resilience engendered by coping strategies, we further extend current theory about the positive outcomes of the resilience process in at least two ways. On the one hand, past research on resilience outcomes focused predominantly on successful performance (i.e., GPA) as an indicator of positive adjustment. However, students' attitudes and beliefs are more proximal outcomes (Baker et al., 2003) and may be better able to predict eventual academic-related behaviors, such as performance. Thus, in this research, we included academic satisfaction as a measure of positive academic outcomes and found that academic resilience is a significant antecedent of satisfaction. The role of academic resilience in predicting satisfaction seems particularly encouraging, as it suggests that a higher level of resilience is associated with increased satisfaction with their academic context. Hence, in stressful situations like the academic context, the development of resilience could be a useful mean to enhance satisfaction among students. On the other hand, in contrast to our expectations, we found that resilience is not directly related to performance over time, suggesting that resilience is instead associated to positive behaviors (i.e., performance) via satisfaction. Although further investigation is needed, this result seems to turn about the recognized statement that higher resilience is a predictor of better performance (Luthar, 2001). A number of possible explanations can be provided to explain this unexpected result. While resilience may influence academic performance, so do many other circumstances and student characteristics, such as performance self-efficacy, grade goal, and effort regulation (Richardson, Abraham, \& Bond, 2012). Moreover, we suggest that academic resilience does not have a direct impact on performance because the process of bouncing back is not necessarily directly related to an increase in performance. In fact the increase would be if there was a psychological process engendered by resilience that - through an increase in motivational states or attitudes (i.e., satisfaction) - affects performance.

Finally, unexpected results revealed the direct effects of the selected coping strategies on academic outcomes. Specifically, we found a direct relationship that links 
problem-solving coping with both academic satisfaction and performance, thereby providing evidence that the cumulative effect of using problem-solving strategies across a range of stressful situations results in better outcomes. Because problem-solving coping involves strategies to alter or diminish a stressful event, it seems plausible that it is positively related with satisfaction and performance. For instance, if the stressor is an impending assignment, focusing on the assignment should result in getting the assignment handed in on time, and getting a good grade (MacCann \& Hicks, 2011). Therefore, students who tend to deal with or change the situation when they are faced with stressful events are more satisfied and attain a higher GPA. Furthermore, we found a direct relationship between social coping and performance. There are several possible pathways by which social coping strategies may influence academic performance. First, students who are able to regulate their negative emotions through venting or support seeking could be less impaired by negative emotions in assessment and learning situations. Second, in the Spanish context, academic performance requires not just passing examinations, but increasingly calls for collaboration and teamwork, for instance in the form of group projects and collective presentations (Ahles \& Bosworth, 2004). Social coping has been linked with better social relationships, suggesting that individuals using this kind of coping could be better able to maintain the social relationships required for effective group work, and in this way achieve higher grades (MacCann et al., 2011).

\section{Implications for practice}

In terms of practical implications, we may conclude that the AR-S is a valid and reliable instrument for measuring resilience in the Spanish academic context. Additionally, this questionnaire contains only 6 items to measure resilience and is therefore a short and practical instrument. The AR-S can thus be considered a solid tool for evaluating and conducting research on academic resilience.

Another important point underpinning the present study concerns the proposition that both coping strategies and academic resilience can be influenced in a direct way. Thus, the practical implication of the study is that in the university context, both coping strategies and resilience can be taken as tools to boost students' outcomes, especially for those who are underperformers or low on satisfaction. Given that our results suggest that academic resilience is enhanced by specific coping strategies, interventions aimed at teaching and encouraging problem-solving and positive acceptance coping strategies 
seem to be crucial. In this regard, there are several interventions that are usually designed to teach individuals how to cope with adversity. They typically include techniques that help the individual to deal with and to handle stress, such as positive reappraisal and problem-solving behaviors (see MacCann et al., 2011).

Moreover, evidence showed that resilience can also be developed through interventions. For example, Fredrickson, Tugade, Waugh, and Larkin (2003) suggested that repeated exposure to positive emotions may help to strengthen an individual's resilience capacity. Specifically, positive emotions may take the form of laughter or smiles and such emotions may reinforce or strengthen resilience (Bonanno, Noll, Putnam, O’Neill, \& Trickett, 2003). Though these types of positive emotions seem simplistic, their effects may be important. Taken together, these guidelines suggest that coping and resilience could be modifiable and doing so may lead to enhanced positive academic outcomes.

\section{Limitations and research directions}

This study has several limitations which highlight important avenues for future research. With the exception of academic performance rates (i.e., GPA), perhaps the clearest limitation is the use of self-reported data, which increases the risk of common method bias (Podsakoff, MacKenzie, Lee, \& Podsakoff, 2003). Although we consider that the use of self-reports could be justified by the nature of the constructs, because the students are the most accurate source of their own strategies and feelings or attitudes, it introduces the possibility of response acquiescence and precludes discussion of causality. We tried to minimize such errors by differentiating the response scales for each of these variables, as suggested in Podsakoff, MacKenzie, and Podsakoff (2012).

Another limitation of the present study is that data are cross-sectional, with the exception of the GPA, which is collected at a different point in time (i.e., between 4 and 5 months later). Although SEM analysis gives some information about the possible direction of the relationships, cross-sectional study designs do not allow one to draw firm conclusions regarding the causal ordering among the variables studied. Clearly there is a need for longitudinal studies that may allow stronger causal inferences to be made about the relationship between coping strategies, resilience, and a range of academic outcomes.

In addition, although our findings are interesting and the sample came from four different faculties and several degrees, our results are based on a sample from the same 
university. Thus, the results need to be replicated in order to allow our findings to be generalized to different academic contexts.

\section{Concluding remarks}

Although research on academic resilience is usually focused on students who encountered greater adversity, it is important to recognize its importance for university students as a whole, because all of them have to deal with adverse and stressful situations during their academic experience. The results of the current study imply that the Spanish translation of the AR-S can be used in a valid and reliable way to measure academic resilience. This measure may thus be used to investigate the relationship of academic resilience with relevant antecedents and outcomes. In this sense, our results offer new insights into how university students can benefit from using adequate coping strategies in order to support the development of their resilience, in order to achieve positive academic outcomes, such as satisfaction and performance. These findings hold implications for researchers investigating the processes students use to deal with everyday academic setbacks, as well as for practitioners seeking to assist students in dealing with the highs and lows that characterize academic life. 


\title{
CHAPTER 6
}

\section{Social Context and Resilience as Predictors of Job Satisfaction and Performance: \\ A Multilevel Study over time ${ }^{5}$}

\begin{abstract}
Overall job satisfaction is the attitude that has received most attention in organizational research and frequently it has been suggested that it is a key factor influencing job performance. Although it reflects individual experiences, it is likely to be affected by attributes of both the individuals and the context in which they operate. This study explores the predicting role of individual work resilience and shared work-unit perceptions of social context $(\mathrm{PoSC})$ on job satisfaction over time, as well as the relationship between job satisfaction and performance rated by supervisors. A sample of 305 white-collar employees, clustered in 67 work-units, participated in the study. Hierarchical linear modeling highlighted that: a) shared PoSC and work resilience are multilevel predictors of job satisfaction; b) shared PoSC are positively related to work resilience; c) job satisfaction is positively related to job performance; d) job satisfaction fully mediates the relation between work resilience and job performance, as well as the relation between shared PoSC and job performance. The findings suggest the pivotal role of job satisfaction in predicting job performance. At the practical level, these results suggest ways to enhance job satisfaction and thus job performance by increasing shared PoSC and work resilience.
\end{abstract}

Key words: Resilience, Social Context, Job Satisfaction, Performance, Hierarchical Linear Modeling

\footnotetext{
${ }^{5}$ Chapter 6 has been submitted for publication as: Meneghel, I., Borgogni, L., Miraglia, M., Salanova, M., \& Martínez, I. M. Social Context and Resilience as Predictors of Job Satisfaction and Performance: A Multilevel Study over time. Applied Psychology: An International Review.
} 


\section{Introduction}

Many people spend a significant amount of time in their workplace, and the feelings of work-related satisfaction or dissatisfaction contribute to overall quality of life and psychological well-being (Judge \& Watanabe 1993; Wright, Bennett, \& Dun, 1999). Beyond the value of positive feelings for the individual, the benefits for organizations have been widely investigated, and the impact of job satisfaction on several organizational outcomes being stressed in many cases (e.g., Judge \& Kammeyer-Mueller, 2012; Spagnoli, Caetano, \& Correia Santos, 2012). Moreover, the link between job satisfaction and job performance has long been of interest to organizational psychologists and several studies have suggested that job satisfaction is a key factor influencing productivity and job performance (Judge, Bono, Thoresen, \& Patton, 2001; Riketta, 2008).

Up to now, job satisfaction has been studied mainly at the individual level, focusing on characteristics of employees like self-efficacy, core self-evaluation, and dispositional affect (Fernández-Ballesteros, Díez-Nicolás, Caprara, Barbaranelli, \& Bandura, 2002; Judge \& Kammeyer-Mueller 2012). A few studies have related work resilience and job satisfaction (Larson \& Luthans, 2006; Youssef \& Luthans, 2007), showing that individuals with higher levels of resilience, even when they experience negative events in the workplace, are more likely to positively adapt and successfully bounce back from these events, and this can enhance their job satisfaction. However, these few studies are above all correlational and cross-sectional, and for this reason it is difficult to establish causal relationships. Although job satisfaction reflects an evaluation of individual experiences, it is also likely to be affected by the attributes of the context in which the individual operates (Ostroff, 1992, 1993). Social environment variables, such as relationships with coworkers and supervisors, are especially closely related to job satisfaction and predict satisfaction levels above and beyond characteristics of the work itself (Judge \& Kammeyer-Mueller, 2012; Morgeson \& Humphrey, 2006). In this regard, Borgogni and colleagues (Borgogni, Dello Russo, Di Tecco, Alessandri, \& Vecchione, 2011; Borgogni, Petitta, \& Mastrorilli, 2010) introduced the concept of "Perceptions of Social Context" $\left(\mathrm{PoSC}^{6}\right)$ as the individual's perceptions of the more relevant social constituents internal to the organization (i.e., top management, immediate supervisor, and colleagues). At the aggregated level, PoSC

\footnotetext{
${ }^{6}$ Presented in previous studies with the acronym PoC, that is Perception of Context (Borgogni et al., 2011).
} 
could work as a broad concept reflecting the overall work-unit perception of the social environment.

As a consequence, it seems imperative to study the antecedents of job satisfaction from a multilevel point of view, although to date evidence in this sense is limited. In order to describe the interrelationships among variables measured at different levels (i.e., individual and collective), strategies of analysis which explicitly account for the nested nature of data and take into consideration all potential group membership effects when examining the hypothesized relationships were required (Hofmann, Griffin, \& Gavin, 2000; Raudenbush \& Bryk, 2002). The present research aims to help make up for this lack by studying the individual- and group-level predictors of individual job satisfaction over time, through multilevel analyses conducted on data gathered at two different time-points. Our purposes are multiple. First, we aim to corroborate the relationship between job satisfaction and performance. Second, we intend to confirm the relationship between resilience and job satisfaction over time, as well as the cross-level effects of unit-level PoSC on individual-level job satisfaction over time. Third, we examine the relationship between unit-level PoSC and resilience. Finally, we investigate the extent to which job satisfaction mediates the relationship between work resilience and performance as well as between PoSC and performance. These hypothesized are introduced below.

\section{Job Satisfaction and Job Performance}

Conceptually, job satisfaction is defined by Judge and Kammeyer-Mueller (2012, p. 347) as "... an evaluative state that expresses contentment with, and positive feelings about, one's job". That is, it is a broad construct that comprises all or most of the characteristics of the job itself and the work environment, which employees find rewarding, fulfilling and satisfying (Weiss, 2002). The causal relationship between job satisfaction and job performance has long been controversial (Judge \& KammeyerMueller, 2012) because evidence about this relationship comes primarily from crosssectional studies, and thus it is difficult to assess whether it is the case that job satisfaction causes job performance or if performance leads to satisfaction (Judge et al., 2001). To better clarify this debate, a recent meta-analysis tested the causal links between job attitudes (i.e., job satisfaction and organizational commitment) and performance, focusing on 16 longitudinal research studies (Riketta, 2008). The results showed that, controlling for baseline performance, job satisfaction significantly 
influenced subsequent both in- and extra-role job performance, while the reverse causal effect was not statistically supported. This could be explained with the theoretical background that identifies job attitudes as proximal antecedents and guidelines of behavior (e.g., Fishbein \& Ajzen, 1974), and also referring to the energizing and facilitative effects of positive affect (as one component of satisfaction) in the workplace (e.g., Staw, Sutton, \& Pelled, 1994). Consistent with the above-cited empirical and theoretical evidence, we posit that the more employees are satisfied with their job, the more likely they are to engage in positive behaviors on the job, thus performing what is required of them. For this reason, we propose the following hypothesis:

Hypothesis 1: Job satisfaction will positively predict job performance.

\section{The (multilevel) antecedents of Job Satisfaction}

Traditionally, studies on job satisfaction have focused on employees' characteristics as salient antecedents (Judge \& Kammeyer-Mueller, 2012). However, it is also important to consider other determinants, taking into account the context where the individuals live and work. Nowadays, when organizations, as well as the individuals and the teams which they are composed of, often have to face complex and incomprehensible environments characterized by hyper-competition and rapid changes (Sutcliffe \& Vogus, 2003), recent calls have been addressed regarding the need to explore the potential role of resilience in crisis scenarios (Kaplan, Laport, \& Waller, 2013). Resilience in the organizational setting is commonly defined as the process to adjust and thrive amidst adversity and to not only restore functioning back to a "normal" level but also to learn and grow from adversity so as to emerge stronger than before (Sutcliffe \& Vogus, 2003). It is becoming increasingly more common for researchers to view resilience as an important psychological resource that helps the employee to face the demand for flexibility, adaptation, and improvisation in situations characterized by change and uncertainty (Youssef \& Luthans, 2007), as well as the need to find unknown inner strengths and resources to cope effectively (Ganor \& Ben-Lavy, 2003). A principle component of resilience as applied to the workplace is that, after a negative event, the employee bounces back to a higher level of motivation, rebounding beyond homeostasis (West, Patera, \& Carsten, 2009). Although, to date, the literature on workplace resilience is still scarce, previous studies found that employees' level of resilience is related to their job satisfaction, work happiness, and organizational commitment (Larson \& Luthans, 2006; Youssef \& Luthans, 2007). Moreover, Liossis, 
Shochet, Millear, and Biggs (2009) showed that the Promoting Adult Resilience (PAR) program led participants to a significant improvement in their job satisfaction at the 6month follow-up. Based on these previous findings, we argue that resilience will be positively related to job satisfaction. Indeed, job satisfaction reflects individuals' evaluations of various aspects of their job and resilience represents the process of proactively preparing for hardships and minimizing the impact of stressful aspects of the job (Shin, Taylor, \& Seo, 2012). Therefore, when individuals feel that they are resilient at work, they are more likely to evaluate their job positively and to naturally experience higher satisfaction with it. Thus, we advance the following hypothesis:

Hypothesis 2: Employees' resilience will be positively related to job satisfaction.

A substantial body of research has shown that perceptions of one's context influence human responses, such as job satisfaction (Pritchard \& Karasick, 1973; Schnake, 1983). It is likely that employees derive their job satisfaction from a context that they perceive as positive (Judge, Bono, \& Locke, 2000). In this regard, PoSC are representative of the individual's perceptions of the more relevant social constituents within the organization, namely top management, immediate supervisor, and colleagues, which relate to both productive and socio-emotional aspects of interactions. Both aspects are taken into account because evidence showed that work groups carry out and pay attention simultaneously to two kinds of behaviors: the task-related behaviors, which are instrumental to goal achievement and production, as well as the relations-care behaviors, which respond to the inner needs of individuation and belongingness (Bales, 1950). As a consequence, PoSC differ from constructs as perceived social support, which are mainly related to positive social relationships and care for employees' wellbeing (Ho \& Gupta, 2014). Moreover, while perceived social support usually refers to co-workers and supervisors (Ho \& Gupta, 2014; Lim, 1996), PoSC simultaneously measure the perceptions of top management, supervisor, and colleagues. Previous studies have demonstrated how individual PoSC can shape employees' work attitudes, like job satisfaction (Borgogni, Dello Russo, Petitta, \& Vecchione, 2010; Borgogni et al., 2011; Parker et al., 2003).

However, PoSC could be considered shared perceptions of prototypical components of social contexts (Borgogni, Petitta, et al., 2010); in fact, perceptions originate within the person, but they are also a result of being exposed to intense situations which converge on consensual collective perceptions (Kozlowski \& Ilgen, 2006). Accordingly, we assume that employees may develop positive job attitudes not 
only when they favorably perceive the organizational constituents, but also when they share these positive perceptions. Employees collectively share the same work environment and the same leader, and ultimately create a bounded context that should lead to a common interpretation, understanding, and attitudinal evaluation of the job experience (Kozlowski \& Hattrup, 1992; Salancik \& Pfeffer, 1978). In line with this assumption, we focused on shared PoSC within the work-units as a key antecedent of individual job satisfaction. Considering these elements together, we suggest that the more the employees shared a positive perception of supervisor, colleagues, and top management, the more they would be satisfied with their jobs. Hence, we expect:

Hypothesis 3: Shared positive perceptions of social context will be positively related to job satisfaction.

We also take into consideration the relationship between the aforementioned antecedents of job satisfaction, namely shared PoSC and work resilience. The resilience literature suggests that learning and growing in the face of adversity depend a great deal on the characteristics of the social environments (Luthar, Cicchetti, \& Becker, 2000) as well as on the existence and the quality of interpersonal relationships (Luthans, Vogelgesang, \& Lester, 2006). Indeed, a supportive climate will likely act as a contextual resource for employees to quickly "bounce back" after setbacks (Luthans, Norman, Avolio, \& Avey, 2008). However, it is important to note that not all relationships are equally valuable for resilience. In fact, relationships can either facilitate or hinder the sharing of information, learning processes, and the development of adaptive solutions to problems (e.g., Paulus \& Nijstad, 2003). Research suggests that high-quality relationships are particularly valuable for resilience because individuals and their teams are better able to collectively comprehend difficult situations and figure out the best way to deal with them (Carmeli, Friedman, \& Tishler, 2013). Thus, individuals draw on their work relationships as a source of strength during times of stress (Kahn, 2005). We consider that PoSC are representative of high-quality relationships because they refer to the perception of positive behaviors enacted by significant organizational constituents and appear to satisfy the core social motives that lead people in their interactions (Fiske, 2004). For this reason, we argue that the more a work-unit shared a positive perception of their supervisor, colleagues, and top management, the more employees were able to develop work resilience. Thus, the following hypothesis is offered: 
Hypothesis 4: Shared positive perceptions of social context will be positively related to individual work resilience.

\section{The mediating role of job satisfaction among multilevel antecedents and individual job performance}

The link between job satisfaction and job performance has been extensively studied (for a review, see Judge \& Kammeyer-Mueller, 2012). However, it is also important to test this association in a framework which includes variables at different organizational levels, such as work-unit shared PoSC and individual work resilience, and to verify the multiple relationships between them by testing the possible mediating role of job satisfaction. Previous research has suggested that resilience leads to an increase in job performance (Luthar, 1991; Luthans, Avolio, Walumbwa, \& Li, 2005), because highly resilient employees are better prepared to rebound or bounce back from adversities, problems, and failures since they are more flexible to changing demands, open to new experiences, and they tend to use setbacks as "springboards" or opportunities for growth (Tugade \& Fredrickson, 2004). Therefore, we expect work resilience to influence employees' performance through job satisfaction. Building on our earlier explanation of the relationships between job satisfaction and performance on the one hand, and the relationships between work resilience and job satisfaction on the other, we predict that high-resilience employees will perform better, because they experience more job satisfaction engendered by resilience. Therefore, we argue that job satisfaction is a partial mediator of the effects of work resilience upon employees' performance, in the sense that more resilient employees, as opposed to those who are less resilient, will experience more job satisfaction, which will in turn lead them to better performance. Thus, we set the following hypothesis:

Hypothesis 5: Employee's work resilience is positively related to job satisfaction, which in turn partially mediates the relationship between resilience and performance.

Consistent with the above-cited empirical evidence and the theoretical background that identifies social contexts as proximal antecedents of job satisfaction, which in turn acts as a proximal antecedent of behavior, we posit that the more positively the work-unit perceives their supervisor, colleagues, and top management to be, the more employees are satisfied with their job, and then the more likely they are to engage in positive behaviors on the job, thus performing what is required of them. Previous research confirmed the full mediation of job satisfaction between PoSC and 
performance (Borgogni, Dello Russo et al., 2010; Borgogni et al., 2011), although in these studies all the variables were always at the individual level. As innovation, we propose that this relation persists even in the case of shared PoSC. Accordingly, we advance the following hypothesis:

Hypothesis 6: Shared positive perceptions of social context are positively related to job satisfaction, which in turn fully mediates the relationship between perceptions of social context and performance.

\section{Method}

\section{Participants and Procedure}

A longitudinal study was conducted in the headquarters of one of the largest service companies in Italy, with a staff of about 150,000 employees working in the 14,000 offices located throughout the country. The first data collection (Time 1) was carried out in June 2010, and a total of 857 employees filled in the questionnaire out of the 1,158 who were initially contacted (response rates of $74 \%$ ). The second set of data (Time 2) were collected in February 2012 and 935 employees answered the questionnaire of the 1,493 involved (response rate 63\%). The final sample consists of 305 employees who responded at both times and could be clearly referred to as a workunit, defined as a unit of employees that have been assigned to accomplish tasks in a specific area and have the same supervisor. Participants were white-collar employees working in a variety of functional areas and were distributed in 67 work-units, consisting of an average of 4.55 employees from each group. A total of $53.4 \%$ of the employees sampled were male, the average age was 45 years $(\mathrm{SD}=8.21)$, and the average organizational tenure was 15.15 years $(\mathrm{SD}=10.14)$.

For both times, employees received an email from the HR department, announcing the research, and one from the researchers, explaining the project and the web-based questionnaire. Participation was voluntary, and each respondent was assigned a code by the HR department, corresponding to his or her questionnaire. The aim of this was to match the answers to the questionnaire with the performance ratings assessed by the supervisor and, at the same time, to guarantee privacy.

\section{Measures}

The measures included: a) self-reports from the questionnaires of work resilience, PoSC and job satisfaction; and b) employees' job performance provided by the HR 
Department as an objective measure. All items were rated on a 7-point Likert scale $(1=$ strongly disagree to 7 = strongly agree).

Work resilience. To assess employees' resilience at Time 1, a 9-item scale was developed $a d-h o c$ for the specific organizational context. Items were generated through some meetings with key managers of the organizations, using Flanagan's (1954) critical incident technique in order to focus on the specific work context. Unlike previous measures, which have generally assessed protective factors or resources involving personal characteristics and coping styles (e.g., Connor \& Davidson, 2003), items were framed as statements of work-related abilities to bounce back, resist illness, adapt to stress, or thrive in the face of adversity, in accordance with the conceptualization of Smith and colleagues (2008). More specifically, the present scale aims at assessing resilience as bouncing back from stress in organizations; hence, contrary to existing broader scales, our items specifically refer to resilience in the job context. An example item is: "I overcome all frustrations related to my failures".

As exploratory factor analysis (EFA) is typically used in the process of scale development and construct validation (Brown, 2006), we conducted a principal factor analyses (PFA) in order to explore the factorial structure of the work resilience scale, using a sample of 555 employees who participated in the Time 1 survey but were removed from the final sample of the present study. The results showed that the factor solution explained $43.96 \%$ of the total variance and the factor loadings of the 9 items of the scale ranged between .57 and .74 , thus indicating a solid factor (Costello \& Osborne, 2005). Additionally, the Cronbach's alpha coefficient of the scale was .87. In order to confirm the structure of the work resilience scale, we performed a confirmatory factor analysis (CFA) on the study sample $(n=305)$, using the Mplus software (Muthén \& Muthén, 1998). The results of the CFA suggested that the 9-item scale fits the data well: $\chi^{2}(27)=71.97, \mathrm{CFI}=.94$, TLI $=.92$, SRMR $=.04(\mathrm{Hu} \&$ Bentler, 1999), and RMSEA $=.08$ (Browne \& Cudeck, 1993). The Cronbach's alpha for this scale was .82.

Perception of Social Context. A 17-item scale was used to assess employees' perceptions of social context (PoSC) at Time 1. The scale was previously validated in the same organizational context (Borgogni, Dello Russo et al., 2010) and consolidated through a meta-analytic procedure in various organizations (Borgogni et al., 2011).

The scale consists of three dimensions:

a) Immediate supervisor. Five items assessed the employees' perceptions of their immediate supervisor in supporting and assisting co-workers, encouraging their 
involvement, treating them equally, taking care of their professional development (e.g., "My immediate supervisor takes care of my professional growth").

b) Colleagues. Four items measured the individuals' perceptions of relationships among colleagues regarding their reciprocal trust, integration of competences, mutual support, and cooperation in facing obstacles (e.g., "In my office people trust each other").

c) Top management. Eight items referred to participants' perceptions of top management's actions with regard to their attention to employee development, the communication of organizational goals, procedures and policies, the integration of units, and the fair treatment of workers (e.g., "Top management is interested in employees' well-being").

The three dimensions have been aggregated in order to investigate the employee perceptions of social context as a unique construct in order to emphasize the whole set of conditions in which an employee is deeply embedded and whose elements are strictly interrelated with one another. That is, at the aggregated level, PoSC could work as a more general concept reflecting the overall perception of the social environment. The Cronbach's alpha for the entire scale was .78.

Job satisfaction. Three items, adapted from the job satisfaction scale of Judge, Locke, Durham and Kluger (1998), were used to assess employees' job satisfaction at Time 2. We used those items positively worded, that is: "I feel fairly satisfied with my job", "I am enthusiastic about my work", and "I am finding real enjoyment in my work". The Cronbach's alpha for this scale was .89.

Job performance. Data on respondents' performance were drawn from the performance appraisal system at Time 2 . The measure reflects the overall ratings of job performance by supervisors and refers to the same year as the second survey. Performance was assessed on a 10-point scale (from $1=$ "Inadequate" to $10=$ "Beyond the expectations") and includes five behavioral domains, namely "customer focus" (i.e.," to anticipate clients' needs and expectations); "innovation" (i.e., to think up and develop innovative solutions); "integration" (i.e., to build up constructive relationships in order to achieve common goals), "problem solving" (i.e., to identify problems correctly and find appropriate solutions), and "openness" (i.e., to explore new opportunities that contribute to the organizational change process). A PFA supported a one-factor structure, suggesting that a single performance factor underlies the five behavioral 
domains. The factor solution explained $81.32 \%$ of the total variance and the coefficient alpha for the composite measure was .94 .

\section{Data Aggregation}

The data of the present study were hierarchically structured such that 305 employee-level cases (level 1) were nested within 67 work-units (level 2). Work resilience, job satisfaction, and job performance were used at level 1 (employee). Perceptions of social context were aggregated at level 2 (work-unit); according to multilevel theory, this is defined as a direct consensus model (Chan, 1998). To evaluate the effect of group membership on parameter estimated, the following tests were conducted: Average Deviation index $\left(\mathrm{AD}_{\mathrm{M}(\mathrm{J})}\right.$; Burke \& Dunlap, 2002) was used to assess inter-rater agreement; reliability was assessed using the intraclass correlation coefficient - ICC(1) (Bliese, 2000); and one-way analyses of variance (ANOVA) were used to test for statistically significant differences between work-units (Kenny \& LaVoie, 1985). Conventionally, values of 1.2 have been used as the traditional upperlimit cut-point using a 7-point scale for $\mathrm{AD}_{\mathrm{M}(\mathrm{J})}$ (Burke \& Dunlap, 2002), whereas values greater than .12 for ICC(1) are considered sufficient evidence to justify aggregation (Bliese, 2000). The sizes of the $\mathrm{AD}_{\mathrm{M}(\mathrm{J})}$ and $\operatorname{ICC}(1)$ indices were 1.03 and .18, respectively, indicating an adequate fit. Moreover, one-way ANOVA verified the existence of statistically significant differences between work-units, $F(66,304)=$ $2.215, p<.001$. Taken together, the reported indexes provided empirical justification for data aggregation in order to create the work-unit level PoSC.

\section{Data Analyses}

In order to test our hypotheses, we used hierarchical linear modeling (HLM) (Bryk \& Raudenbush, 1992) as a statistical framework for our data analyses by using LISREL 8.8 (Jöreskog \& Sörbom, 2006). Conventional statistical analyses violate the assumption of independence of observations because of the hierarchical structure of the data, which may lead to spurious results (Hox, 2002). However, multilevel regression analyses take into account the potential group membership effects when examining the hypothesized level-1 relationships, as well as when examining the hypothesized crosslevel relationships. That is, they allow us to make simultaneous inferences on the effects of variations in the independent variables at the individual level and work-unit level on the dependent variables. In Bryk and Raudenbush's (1992) notation, this is the form of the model: 
Level 1: Performance T2ij $=\beta 0 \mathrm{j}+\beta 1 \mathrm{j}($ Resilience T1ij $)+\beta 2 \mathrm{j}($ Satisfaction T2ij $)+$ rij

Level 2: $\beta_{0 \mathrm{j}}=\gamma_{00}+\gamma_{01}\left(\operatorname{PoSC} \mathrm{T} 1_{\mathrm{j}}\right)+\mathrm{u}_{0 \mathrm{j}}$

$$
\begin{aligned}
& \beta_{1 j}=\gamma_{10} \\
& \beta_{2 j}=\gamma_{20}
\end{aligned}
$$

In the analyses, all predictor variables were grand-mean centered to facilitate model estimation (Hofmann \& Gavin, 1998). As stated in the last two rows of the equation, the slopes between individual-level variables (resilience at Time 1 and satisfaction at Time 2) are fixed, and therefore they are not allowed to randomly vary across groups.

In order to test Hypotheses 5 and 6 concerning mediation, we examined the four conditions for mediation suggested by Baron and Kenny (1986): (1) the independent variables should be related to the dependent variable; (2) the independent variables should be related to the mediator; (3) the mediator should be related to the dependent variable, controlling for the independent variables; and (4) for full mediation, the effect of the independent variables on the dependent variable is reduced to non-significance when the mediator's effect on the dependent variable is taken into account. If the fourth condition is not met, partial mediation is concluded. Finally, because recent research suggests that the Baron and Kenny mediation test is too conservative and that indirect effects can still be significant when Baron and Kenny's criteria are not fully met (MacKinnon, Lockwood, Hoffman, West, \& Sheets, 2002), we also tested the mediation hypotheses (Hypotheses 5-6) using Sobel's (1988) test of indirect effects, which MacKinnon et al. (2002) found to provide a better balance between Type I and Type II errors.

\section{Results}

We initially checked our data for normality (Muthén \& Kaplan, 1985). The assumption of normality was not violated. The results of the analyses can be obtained from the first author upon request. Table 6.1 presents the means, standard deviations, and correlations among the variables at the individual level. As can be seen, the correlations between work resilience and PoSC were significant and positive, as were their correlations with job satisfaction. In turn, job satisfaction showed a significantly positive correlation with job performance. No significant correlations were found between work resilience and job performance or between PoSC and job performance. 
Table 6.1

Means, Standard Deviations, and Correlations among variables $(N=305)$

\begin{tabular}{lcccccc}
\hline & $M$ & $S D$ & 1 & 2 & 3 & 4 \\
\hline 1. PoSC (T1) & 4.76 & .91 & - & & \\
2. Work Resilience (T1) & 5.49 & .65 & $.38^{* *}$ & - & \\
3. Job Satisfaction (T2) & 5.03 & 1.04 & $.38^{* *}$ & $.29 * *$ & - & \\
4. Performance (T2) & 7.73 & 1.02 & .04 & .08 & $.13^{*}$ & - \\
\hline
\end{tabular}

Note. PoSC $=$ Perception of Social Context; T1 = Time 1; T2 = Time 2.

$* p<.05, * * p<.01$.

\section{Multi-level Analyses and Test of Hypotheses}

In accordance with Hypothesis 1, the relationship between job satisfaction and performance was significant and positive $(\beta=.16, p<.01)$. In support of Hypotheses 2 and 3 , the relationship between work resilience and job satisfaction was significant and positive $(\beta=.45, p<.001)$, as was the relationship between work-unit PoSC and job satisfaction $(\beta=.54, p<.001)$. Furthermore, the relationship between work-unit PoSC and work resilience was also significant and positive $(\beta=.25, p<.01)$, as expected in Hypothesis 4. Then several models were estimated, each differing in the number of predictors that were included in the analysis. In the first model (Model 0) no predictor variables were added and this model was used to determine what percentage of the total variance in the dependent variable (i.e., performance) is between-group variance. As can be seen in Table 6.2, Model 0 reveals that a significant proportion of total variance in individual performance at Time $2(15 \%)$ was explained by work-unit membership. Significant variance between units justifies the inclusion of predictors at the unit-level of analysis.

Once significant between-unit variance has been demonstrated in Model 0 , individual-level predictors (i.e., work resilience and job satisfaction) are included in Model 1. As shown in Table 6.2, a significant result was observed for job satisfaction, indicating that job satisfaction is significantly related to performance. However, there is no significant relationship between resilience and performance. These results are somewhat in line with our Hypothesis 5, which predicted that employees' job satisfaction would partially mediate the relationships between employees' work 
Table 6.2

Hierarchical Linear Models results

\begin{tabular}{lccc}
\hline & \multicolumn{3}{c}{ DV $=$ Performance (T2) } \\
\cline { 2 - 4 } \multicolumn{1}{c}{ Variables } & Model 0 & Model 1 & Model 2 \\
\cline { 2 - 4 } Intercept & $7.75^{* * *}(.08)$ & $7.04 * * *(.29)$ & $6.99 * * *(.30)$ \\
Resilience (T1) & & $.06(.09)$ & $.06(.09)$ \\
Job Satisfaction (T2) & & $.14 *(.06)$ & $.15 *(.06)$ \\
Work-unit PoSC (T1) & & .17 & $-.12(.17)$ \\
\hline Pseudo R-squared & .15 & $.17 *(.07)$ & $.17 *(.07)$ \\
Variance level 2 & $.16^{*}(.07)$ & $.84 * * *(.08)$ & $.84 * *(.08)$ \\
Variance level 1 & $.89 * * *(.08)$ & 822.94 & 822.38 \\
$-2 *$ log (likelihood) & 846.57 & 5 & 6 \\
$d f$ & 3 & & \\
\hline
\end{tabular}

Note. Pseudo R-squared was calculated as the sum of total variance attributable to within and between variance components (Singer, 1998). PoSC $=$ Perception of social Context; $\mathrm{T} 1=$ Time 1 ; T2 = Time 2 .

$* p<.05, * * p<.01, * * * p<.001$.

resilience and performance. In order to assess mediation, we followed the procedure described above and the results shown in the upper portion of Table 6.3. Following the approach recommended by Baron and Kenny (1986), we first examined the effects of work resilience on performance. The relationship was not significant $(\beta=.12, p=.18$ ), indicating that condition 1 was not supported. However, as revised by Shrout and Bolger (2002), condition 1 is no longer required for mediation as long as the other two conditions are met, and also because requiring a significant relation substantially reduces the power to detect real mediation effects (MacKinnon, Fairchild, \& Matthew, 2007). Second, we examined the effects of resilience on job satisfaction and the relationship was significantly positive $(\beta=.45, p<.001)$, and thus met the second condition. We then examined the effects of job satisfaction on performance controlling 
Table 6.3

Individual-Level and Cross-Level Mediation Analyses

\begin{tabular}{lll}
\hline Step and variable & $\beta$ & $S E$
\end{tabular}

Individual-level tests

$\mathrm{DV}=\mathrm{Job}$ satisfaction

1. Work resilience $\quad .45 * * * \quad .09$

DV $=$ Performance

1. Work resilience

2. Work resilience

Job satisfaction

.06

\section{Cross-level tests}

$\mathrm{DV}=\mathrm{Job}$ satisfaction

1. Work-unit PoSC

$\mathrm{DV}=$ Performance

1. Work-unit PoSC

$-.02$

.16

2. Work-unit PoSC

Job satisfaction

Note. DV = dependent variable; PoSC = Perception of Social Context.

$* p<.05, * * p<.01, * * * p<.001$.

for the effect of resilience. The relationship was significantly positive $(\beta=.14, p<.05)$, thereby supporting the third condition. Last, we found that the relationship between resilience and performance was not significant when the mediator was present $(\beta=.06$, $p=.52$ ), as expected in the light of the non-significant results of the condition 1 test. In sum, conditions 2 and 3 of Baron and Kenny's (1986) tests for mediation were satisfied while conditions 1 and 4 were not. Nevertheless, based on the revised criteria (Kenny, Kashy, \& Bolger, 1998), Hypothesis 5 is partially supported given that job satisfaction fully mediates the relationship between resilience and performance. Additionally, Sobel's test was performed with the partial estimates and standard errors from Table 6.3 
and it was significant $(t=2.20, p<.05)$, thus supporting this last link in the mediation process. Next, a unit-level predictor (i.e., PoSC) is included in Model 2, and so Model 2 includes both predictors at the individual and group levels. As shown in Table 6.2, there is no significant relationship between PoSC and performance. These results are in line with our Hypothesis 4, which predicted that employees' job satisfaction would mediate the relationships between employees' work-unit PoSC and employees' performance. In order to assess mediation, we also followed the procedure described above and the results shown in the lower part of Table 6.3. Following the approach recommended by Baron and Kenny (1986) we first examined the relationship between work-unit perceptions of social context and employees' performance. The relationship was not significant $(\beta=-.02, p=.92)$, indicating that condition 1 was not supported. Second, we examined the effects of PoSC on job satisfaction and the relationship was significantly positive $(\beta=.54, p<.001)$, thereby meeting the second condition. We then examined the effects of job satisfaction on performance controlling for the effect of PoSC. The relationship was significantly positive $(\beta=.17, p<.01)$ and thus satisfied the third condition. Last, we found that the relationship between PoSC and performance was not significant when the mediator was present $(\beta=-.11, p=.50)$, as expected in the light of the non-significant results of the condition 1 test. In sum, conditions 2 and 3 of Baron and Kenny's (1986) tests for mediation were satisfied while conditions 1 and 4 were not. Nevertheless, based on the revised criteria (MacKinnon et al., 2007; Shrout \& Bolger, 2002), Hypothesis 6 is supported in that job satisfaction fully mediates the relationship between PoSC and performance. Additionally, Sobel's test was performed with partial estimates and standard errors from Table 6.3 and it was significant $(t=2.31$, $p<.05)$, thus supporting this last link in the mediation process. Finally, it should be noted that the final complete model (Figure 6.1) explains $17 \%$ of the variance of performance. 
Figure 6.1. The final model with standardized path coefficients $(N=305)$. Dotted line shows no significant path.

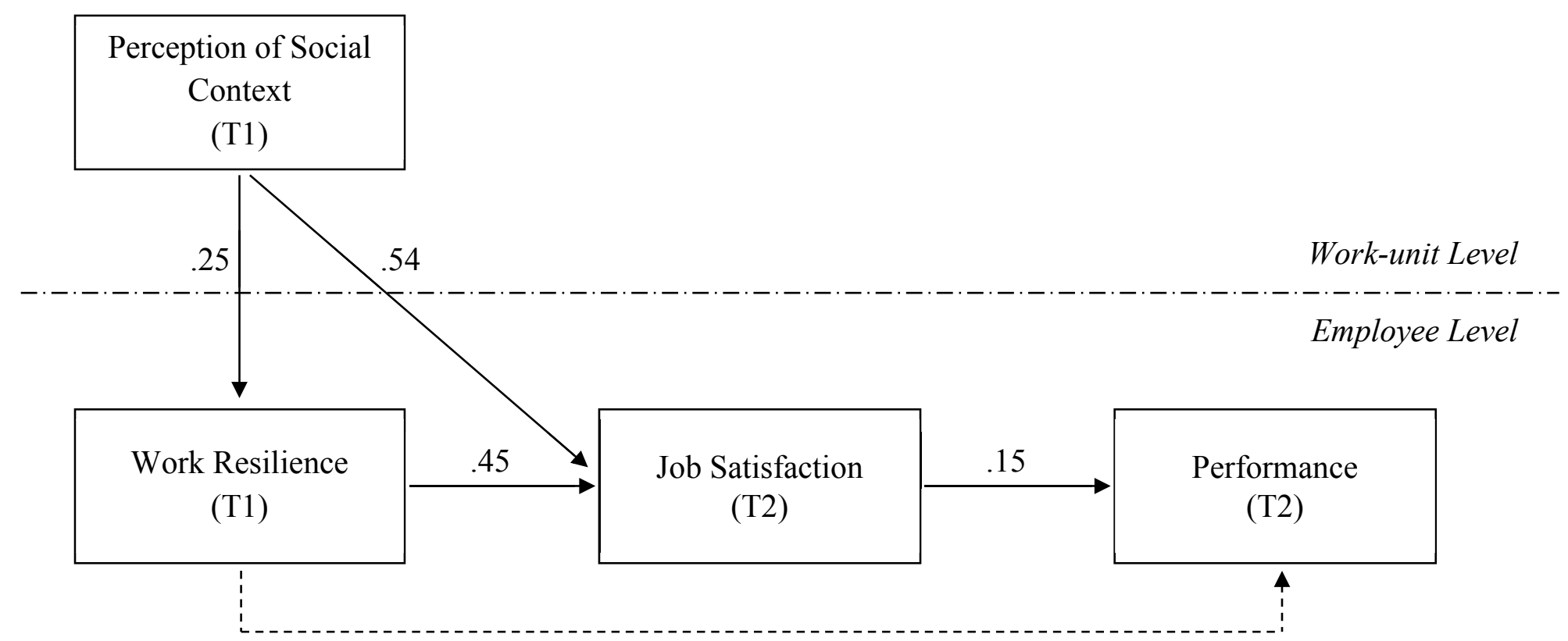




\section{Discussion}

Taken together, our findings lead us to draw several conclusions. First, we provide empirical evidence for the positive relationship between job satisfaction and job performance at the individual level of analysis (supporting Hypothesis 1). Second, our results offer an innovative account of the multilevel predictors of job satisfaction. In fact, work resilience and shared PoSC were shown to exert a positive effect on individual job satisfaction, at the individual and cross levels respectively (supporting Hypotheses 2 and 3). In addition, our results suggest that shared PoSC represent an important social environment affecting individual work resilience (supporting Hypothesis 4). Finally, results indicate that PoSC and work resilience were indirectly, positively related to employees' performance through job satisfaction. That is, job satisfaction is the pathway through which work resilience and shared PoSC promote employees' performance (partially supporting Hypothesis 5 and supporting Hypothesis 6). Our findings provide several implications for research and practice.

\section{Theoretical contributions}

First, our study gives evidence about and enhances the validity of the satisfactionperformance relationship. While a lasting debate about the nature and the strength of relationships between the two constructs has been of interest to organizational psychologists, our results corroborate the more established evidence which suggested that satisfaction-to-performance was stronger than the performance-to-satisfaction link (Judge \& Kammeyer-Mueller, 2012; Riketta, 2008).

The second implication underscores the relevance of adopting a multilevel view of job satisfaction and performance predictors. Indeed, we detected direct relationships of individual work resilience and work-unit PoSC with job satisfaction, as well as indirect associations with job performance via individual job satisfaction. These results have several implications. First, extending previous work, our findings indicate that job satisfaction helps to explain the relationships of individual and work-unit level variables with performance. Second, the role of work resilience in predicting job satisfaction over time seems particularly encouraging, as it suggests that the more employees are resilient, the more they are satisfied with their work. Previous evidence has shown that resilience can be developed through training sessions (Luthans et al., 2006), therefore, especially in difficult situations like the current economic crisis, resilience could be strengthened to promote employees' capabilities of overcoming challenges and strain, 
thereby enhancing their satisfaction. Third, we found that high levels of work-unit PoSC provide a shared positive organizational context that enhances employees' job satisfaction over time. Although it is well-known that employees are more satisfied when they perceive organizational constituents positively (e.g., Borgogni, Dello Russo et al., 2010), our result is remarkable because it extended this link to the work-unit level, while previous research focused on just the individual level. Finally, in contrast to our expectations, we found that resilience is not directly related to performance, suggesting that resilience is instead associated to favorable work-related behaviors (i.e., performance) via job satisfaction. This result is noteworthy because, to our knowledge, this is the first study that explicitly examines the relationship between work resilience and (objective) job performance over time, and it gives evidence of a lack of any direct relationship. Although further investigation is needed, this result seems to go against the widely acknowledged statement that higher resilience is a predictor of better performance (Sutcliffe \& Vogus, 2003).

Finally, we found that PoSC are representative of contextual factors or resources which may better prepare employees to quickly "bounce back" after setbacks. In this light, PoSC can be considered a supportive context that acts as a source of strength during times of stress, through high-quality relationships with salient organizational constituents. The idea that supportive contexts may create the necessary positive conditions for the development of resilience is established in the literature (e.g., Luthans et al., 2008); however, to our knowledge, no other studies have offered evidence for the relation between work-unit level shared PoSC and individual resilience. An important implication of this finding is that researchers need to account for the influence of both individual and work-unit level predictors to more fully explain variance in employees' resilience.

\section{Implications for practice}

Our study indicates that managers should use somewhat different strategies to increase employees' job satisfaction and, in turn, achieve better performance. Firstly, given the importance of work resilience in engendering job satisfaction, activities or interventions should focus on the development of employees' resilience. Consistent with Luthans and colleagues (2006), both proactive and reactive approaches can be proposed to enhance individual resilience. The first approach involves structuring the organization around the anticipation of the need for resilience, and this can be achieved 
through three strategies: (a) proactive prevention and reduction of risk or stress, (b) enhancement of personal and available organizational resources, and (c) improvement of employees' psychological capital. The second approach is more reactive and mainly drawn from the Broaden-and-Build Theory of positive emotions (Fredrickson, 2001), suggesting that repeated exposure to positive emotions may help to strengthen an individual's resilience. Accordingly, activities or interventions could be used to build positive emotional experiences, such as by allowing employees to gain significance and satisfaction from their work, as well as consistently reminding them to think positively and to find meaning when negative events occur to individuals or organizations (Luthans et al., 2006).

In addition, because of the prominent role played by shared PoSC in generating work resilience, job satisfaction and subsequent job performance, suggestions addressing activities or interventions aimed at supporting the engendering or maintenance of a positive social context at work are presented. With this aim, and taking into account the three main constituents of PoSC, practical suggestions are formulated for each of them. To enhance the immediate supervisor's positive perception, interventions may support supervisors in exercising their leadership. With this aim, a coaching program could be suggested to train them to: (a) diagnose individuals' characteristics and the activities that best match them, (b) understand the opportunities and boundaries of each employee in order to support the expression of personal talents, (c) set challenging goals for each employee, (d) deliver constructive feedback that facilitates employee growth, and (e) understand and manage the relationship with employees (Borgogni, Dello Russo et al., 2010).To improve the perceptions of relationships among colleagues, managers should promote a prosocial orientation characterized by cooperativeness and sharing, as well as allow the development of strong and stable within-group relationships, thus ensuring feelings of belongingness and trust. Managers can develop strategies to promote group cooperation and group cohesion (team building and team development). In this regard, it is important to be aware that spiraling processes may substantially influence the affective states and the interpersonal relationships within work-units. Through mechanisms of affective sharing and affective similarity-attraction, a work-unit's employees tend to develop homogenous positive moods and emotions, as well as favorable within-group relationships over time (Walter \& Bruch, 2008). Finally, given their global position, managers may take opportunities to proactively influence and shape the PoSC, both 
regarding themselves and other constituents. Accordingly, top management needs to uphold the clarity of the mission, transparency in communications, conveyance of equity and trust, and integration among different units. For this purpose, they could aim to conduct an organizational analysis to avoid overlaps among roles and positions, to increase interdependence among leaders of the different units, and to set group goals (Borgogni, Dello Russo, \& Latham, 2011). In this sense, intervention may pay attention to (1) enhancing coordination and communication, (2) actively engaging in image management, and (3) developing culture-related issues that fit in with the environment and resolve challenges (Borgogni, Petitta et al., 2010).

\section{Limitations and research directions}

This study has limitations which highlight important avenues for future research. First, our operationalization of shared PoSC did not quantify differences among the effects of each of the three social constituencies. However, taking them all together, PoSC represent the contextual conditions shaped by organizational members' actions and become a source of perceptions of the social climate. Moreover, we obtained higher inter-rater agreement, which shows the consensus of the work-unit members about the PoSC as a whole. Thus, although more research is needed to confirm our findings, our initial results suggest that PoSC can be an important context condition affecting individual self-evaluations and attitudes. In addition, measures taken from the same source at the same time are potentially at risk of common method bias (Podsakoff, MacKenzie, Lee, \& Podsakoff, 2003). This problem may affect only our independent variables. However, the use of self-reports was justified by the nature of the constructs, because the employees are the most accurate source of their own internal perceptions (such as PoSC) and self-evaluations (such as work-resilience). Moreover, the mediator (i.e., job satisfaction) was collected at a different point in time (i.e., 20 months later) and the outcome (i.e., job performance) was derived from a different source, namely from the performance appraisal system, reducing the risk of suffering from common method variance.

Another limitation is related to the construction of the items. In our study, all variables were assessed at the individual level and had the individual as their referent. It should be noted that an explicit work-unit referent would have been more appropriate for those items that referred to PoSC, since they tend to produce less disagreement within groups and more variability among groups (Klein, Conn, Smith, \& Sorra, 2001). 
However, our aggregation indices, namely $\operatorname{ICC}(1)$ and $\mathrm{AD}_{\mathrm{M}(\mathrm{J})}$, always meet the criteria to justify consensus. Another issue related to the construction of the items concerns the fact that work resilience was assessed with a tailored measure that was specifically constructed for this study. Although this measure has the strength to be specific for the particular work context, making it applicable to other work contexts is a more difficult task.

Future studies could compare our measure with another well-established work resilience scale in order to determine its suitability. We encourage researchers to expand the focus from within-person studies to the team and/or organizational level in order to enrich our understanding of organizational processes in a more comprehensive way. For example, as also pointed out by Judge and colleagues (2001), it would be worth knowing whether the satisfaction-performance relationship is stronger at the group or organization (vs. individual) level of analysis. Although some efforts have been made in this direction (e.g., Whitman, Van Rooy, \& Viswesvaran, 2010), the results indicated that satisfaction has different relations with different performance criteria and in different contexts. Consequently, a relevant factor to be taken into account in developing future hypotheses will be to specify appropriate multilevel models. Finally, although our initial findings are encouraging, they are based on a sample taken from a large service company in Italy. Thus, it is important to extend the generalizability of our findings to different organizational contexts, such as small and medium-sized enterprises (SMEs). 


\section{CHAPTER 7}

\section{General Discussion}

The main objective of the present dissertation seeks to add value to the stream of research and to advance our current understanding of resilience by providing theoretical and empirical evidence for its critical role in the organizational context. In order to carry this out, the dissertation is composed of one theoretical chapter (Chapter 2) and four empirical studies (Chapters 3 to 6 ). Whereas the theoretical chapter aims to discuss a number of theoretical and methodological concerns with regard to previous research that has focused on resilience in the organizational context, the four empirical chapters are focused on some of these topics with the objective of looking for significant contributions to the research on resilience. With this purpose in mind, the four empirical studies have been carried out in different organizational domains (i.e., small and medium enterprises, large service company, and education) and countries (i.e., Spain and Italy). Furthermore, different statistical methods have been used (i.e., Exploratory Factor Analyses, Confirmative Factor Analyses, scale validation, Structural Equation Modeling, Path Analyses, Hierarchical Linear Modeling) to test the hypotheses of the studies.

Based on the results from the studies included in this dissertation, several theoretical contributions can be derived. Especially through the empirical chapters, the dissertation addresses three fundamental challenges for research on resilience in its pursuit to adequately capture how resilience can be promoted and what its outcomes in the organization are. In the sections below, the main features of the studies were recapitulated in terms of the three research challenges identified in Chapter 1. Subsequently, the practical implications of our results are discussed, together with limitations and future research directions. Table 7.1 provides an overview of the main features of each empirical study. 


\section{Table 7.1}

Overview of the main features of the empirical chapters

\begin{tabular}{|c|c|c|c|c|c|}
\hline & Sample & Level addressed & Design & Statistical analyses & Variables \\
\hline CHAPTER 3 & $\begin{array}{l}257 \text { work-teams } \\
\text { (52 Organizations) }\end{array}$ & Team level & Cross-sectional & $\begin{array}{l}\text { Moderated Structural } \\
\text { Equation Modeling }\end{array}$ & $\begin{array}{l}\text { - Job demands } \\
\text { - Job Social Resources } \\
\text { - Resilience } \\
\text { - Performance }\end{array}$ \\
\hline CHAPTER 4 & $\begin{array}{l}216 \text { work-teams } \\
216 \text { supervisors } \\
\text { (40 Organizations) }\end{array}$ & Team level & Cross-sectional & $\begin{array}{l}\text { Structural Equation } \\
\text { Modeling }\end{array}$ & $\begin{array}{l}\text { - Positive Emotions } \\
\text { - Resilience } \\
\text { - In-role Performance } \\
\text { - Extra-role Performance }\end{array}$ \\
\hline CHAPTER 5 & $\begin{array}{l}780 \text { students } \\
\text { (1 University) }\end{array}$ & Individual level & $\begin{array}{l}\text { Longitudinal } \\
\text { (two waves) }\end{array}$ & $\begin{array}{l}\text { Scale validation \& } \\
\text { Structural Equation } \\
\text { Modeling }\end{array}$ & $\begin{array}{l}\text { - Coping strategies } \\
\text { - Resilience } \\
\text { - Academic Satisfaction } \\
\text { - Objective Performance }\end{array}$ \\
\hline CHAPTER 6 & $\begin{array}{l}305 \text { employees } \\
67 \text { work-units } \\
\text { (1 Organization) }\end{array}$ & $\begin{array}{l}\text { Individual \& } \\
\text { Team level }\end{array}$ & $\begin{array}{l}\text { Longitudinal } \\
\text { (two waves) }\end{array}$ & $\begin{array}{l}\text { Hierarchical Linear } \\
\text { Modeling }\end{array}$ & $\begin{array}{l}\text { - Perceptions of Social Context } \\
\text { - Resilience } \\
\text { - Job Satisfaction } \\
\text { - Objective Performance }\end{array}$ \\
\hline
\end{tabular}


CHALLENGE 1. How can resilience be conceptualized in the organizational context? Besides the traditional focus on individual resilience, is it worth focusing on team or group resilience?

The first challenge that we aim to address in this dissertation concerns the need to expand knowledge on the significant constituents that are worth focusing on when studying resilience in the organizational context. In accordance with the findings outlined in our theoretical review (Chapter 2), studies usually focus on resilience in individuals rather than on collective, namely team or organizational, resilience. In accordance with Mallak (1998), we believe that resilience in organizations builds upon the foundation of the resilience of the members of that organization. Undoubtedly, an understanding of resilience at the individual level provides a useful insight into the relevance of resilience in the organizational context, as well as a valuable starting place for defining resilience at higher levels, since actions and interactions among individual organizational members underpin the emergence of a collective resilience (Morgeson \& Hofmann, 1999). Nevertheless, organizational reliance on teams has increased significantly in recent years (Costarelli, 2009; Carmeli, Friedman, \& Tishler, 2013) and adversity at this level is becoming more likely because teams today are exposed more directly to highly uncertain environments (Boone, van Olffen, van Witteloostuijn, \& de Brabander, 2004). Thus, as also highlighted throughout the chapter in the dissertation, expanding resilience research at the team level is not only essential but also an absolutely need.

Therefore, throughout this dissertation we direct our attention to resilience among organizational members, addressing both the individual and team levels. Whereas Chapters 3 and 4 focused on establishing teams' antecedents (i.e., team job demands and resources, and collective positive emotions) and consequences (i.e., team performance) of team resilience, in Chapters 5 and 6 resilience was investigated at the individual level. However, while in Chapter 5 antecedents of individual resilience were also examined at the individual level (i.e., coping strategies), throughout Chapter 6 a multilevel approach was utilized and shared work-unit perceptions of the social context were taken into account as antecedents of individual resilience. As a consequence, we consider that it is worth focusing on resilience at different levels in the organizational context, with special attention given to individual and team resilience.

In this regard, in this dissertation we have also offered interesting insights into measures of resilience at different levels in the organizational context. The instruments 
measuring resilience used in this dissertation were chosen guided by two principles: first, resilience is relative and changing in transaction with specific circumstances (Staudinger, Marsiske, \& Baltes, 1993) and, second, to address variables at different levels of analysis requires the use of adequate composition models (Chan, 1998). As a result, different instruments were employed depending on the specific organizational context under study (e.g., work or academic) and measurements of team resilience were framed using the team as the referent in the items (cf. Referent-Shift Consensus model; Chan, 1998). In particular, whereas the instrument measuring team resilience had previously been validated in the context under study, the other two instruments used had to be validated specifically for this research. In this sense, we can conclude that throughout the dissertation we used solid and suitable tools for studying resilience at the individual and team levels. In fact, these instruments allow resilience to be evaluated in different contexts and at diverse levels, as well as making possible to relate it to other variables.

Overall, with this dissertation our intention was to depict a useful and significant picture of resilience in the organizational context, attending to the salient organizational constituents that can take advantage of the process of resilience to overcome stressful and adverse situations.

CHALLENGE 2. What are the antecedents of resilience in the organizational context? In addition to dispositional antecedents, are there any situational features that help to enhance resilience? Additionally, can the antecedents be conceptualized at different levels of analysis?

The second challenge involves two streams of work, which are complementary in their aim to identify which factors can be considered as antecedents that promote the development of resilience in organizations. First, we investigated the extent to which some selected dispositional and situational antecedents enhance the development of resilience. Second, attention was paid to multilevel antecedents of resilience, thus going beyond the traditional focus at the individual level of analysis, and taking into consideration team-level factors.

\section{Dispositional and situational antecedents}

Regarding the distinction between dispositional and situational antecedents of resilience, both of them are studied in the current dissertation. Although past research focused mainly on the dispositional ones, evidence from the organizational context is 
still scarce and for this reason we decided to pay attention to both of them. Thus, in Chapter 4 we examined whether collective positive emotions drive the within-team experience to promote favorable reactions, thereby enhancing team resilience, based on a previous theoretical proposal and empirical evidence at the individual level coming from the B\&B Theory (Fredrickson, 1998; 2001). Specifically, this theory assumes that positive emotions appear to broaden people's momentary thought-action repertoires by producing patterns of thought that are particularly unusual, flexible, creative, and open to information and, in this way, they help in building enduring resources, such as resilience (Tugade \& Fredrickson, 2004). Whereas these assumptions are usually proposed at the individual level of analysis, throughout this dissertation it has been shown that positive emotions (i.e., enthusiasm, optimism, satisfaction, comfort, and relaxation) can be collectively shared through different mechanisms of affective sharing (i.e., emotional contagion and comparison, and empathy) and they thus help teams to develop resilience. Hence, the finding helps to shed light on the processes underlying the relationships between collective positive emotions and team resilience, thereby providing support for the premises of the B\&B Theory, and expanding it to the teamlevel of analysis.

In Chapter 5 we also explored dispositional antecedents of resilience, and in this case we investigated the predicting role of distinct coping strategies on individual academic resilience. Although previous studies had already examined this relationship, they have mainly combined scales into general problem- and emotion-focused categories of coping. In contrast, we advance theoretical understanding of how different kinds of coping strategies affect resilience using a broader categorization that was supported both empirically and theoretically. Specifically, we identified two coping strategies which are positively related with resilience, namely problem-solving and positive acceptance, showing that taking active steps to address the problem and/or generating positive emotions by attributing meaning to the situation should lead to resilience. In this sense, strategies which are more active, both behaviorally and cognitively, are more likely to enhance resilience. In addition, our results showed that there are also two kinds of coping strategies that are negatively related with resilience, namely social and avoidant coping. Therefore, using more social coping strategies, like looking for social support and venting of emotions and/or avoiding and ignoring the problem, should reduce resilience. As can be seen, both these strategies are focused on the reduction of negative emotion, by venting or avoiding them, and do not address the 
situation. Thus, to enhance the development of resilience it is not only important to use active coping strategies, but also to avoid using emotional-focused strategies because they are negatively related with resilience. Hence, by relying on the coping strategies as antecedents of academic resilience, we advance theoretical understanding of how different kinds of coping strategies affect resilience.

In the remaining two chapters, we focused on situational antecedents instead, looking for evidence that link organizational-related factors to the spread of resilience. Specifically in Chapter 3 we explored the extent to which team job demands and resources influence team resilience. These two antecedents of resilience were selected based on the propositions of the JD-R model (Bakker \& Demerouti, 2007; Demerouti, Bakker, Nachreiner, \& Schaufeli, 2001), which suggested that the variety of psychosocial work characteristics can be classified into two broad groups, job demands and job resources, which incorporate different specific demands and resources depending on the context under study. To our knowledge, this study is the first to examine job demands and resources as antecedents of resilience in the organizational context. In Chapter 6 we looked at another kind of situational antecedents of resilience, in this case the work-unit's shared perception of social context. The resilience literature suggests that the characteristics of the social environments as well as high-quality relationships are particularly valuable for resilience because individuals and their teams are better able to collectively comprehend difficult situations and figure out the best way to deal with them (Carmeli et al., 2013). At the aggregated level, perception of the social context could work as a broad concept reflecting the work-unit's overall perception of the social environment in the organization (i.e., supervisor, colleagues, and top management) and thus we investigated it as being representative of high-quality relationships.

The results of this dissertation provide evidence that team job social resources (i.e., team social support climate and team coordination) and shared perceptions of social context (i.e., top management, supervisor, and colleagues) are significant predictors of resilience. These results are consistent with previous resilience literature suggesting that resilience depends a great deal on the characteristics of the social environments as well as the existence and the quality of interpersonal relationships (Luthans, Vogelgesang, \& Lester, 2006; Luthar, Cicchetti, \& Becker, 2000). Although not all relationships and social contexts are equally valuable for resilience (Paulus \& Nijstad, 2003), research suggested that high-quality relationships are particularly 
valuable, since individuals and the teams they comprise are better able to collectively comprehend difficult situations and figure out the best way to deal with them (Carmeli et al., 2013). In this regard, a high level of job social resources and positive PoSC among work-groups can be considered a high-quality supportive context that acts as a source of strength for individuals and teams during times of stress, through positive relationships and interrelationships with salient organizational constituents. Moreover, results showed that the effect of job social resources on team resilience is attenuated when there are high job demands, suggesting that job demands do indirectly impact team resilience through the number of job social resources. This result is in disagreement with previous insights from the Job Demands-Resources Model (Demerouti et al., 2001), which claimed that job resources gain their motivational potential particularly when employees are confronted with high job demands (Bakker \& Demerouti, 2007). Additionally, the result is unexpected in relation to resilience theory, which proposed that implicit within the notion of resilience is exposure to significant threat or adversity (e.g., Luthar et al., 2000; Powley, 2009). For this reason, more research is needed to clarify these points. For instance, high levels of job demands might create an opportunity to develop resilience in the future, while at the same time diminishing current levels of resilience. In this sense, it seems imperative to study this relationship over time, through longitudinal designs. Moreover, taking into account the distinction between challenges and hindrance demands (Crawford, LePine, \& Rich, 2010), we used job demands belonging to both categories and this could blur the result, leading to non-significance. In fact, challenge demands (e.g., workload, time pressure, and high levels of job responsibility) tend to be appraised as stressful demands that have the potential to promote mastery, personal growth, or future gains. In contrast, hindrance demands (e.g., role conflict, role ambiguity, and hassles) tend to be appraised as stressful demands that have the potential to suppress personal growth, learning, and goal attainment. We argue that only challenge demands should be related to resilience, because they are usually perceived as opportunities to learn, achieve, and demonstrate the type of competence that tends to get rewarded. Taking into account a greater number of job demands in both categories, future research should investigate the effects of these categories on resilience in order to understand how the results may differ. 


\section{Multi-level antecedents}

Regarding the conceptualization of the antecedents of resilience, our attention was paid to multi-level ones, thereby going beyond the traditional focus at the individual level of analysis and also taking into consideration team-level factors. Specifically, throughout this dissertation individual-level antecedents have only been considered in Chapter 5 by referring to coping strategies as a driver of individual experience in order to promote favorable reactions. That is, coping refers to the set of cognitive and behavioral strategies used by an individual to manage the demands of stressful situations, and for this reason it is fundamentally an individual factor. Conversely, throughout the remaining chapter, antecedents at the team level were studied in greater depth. Specifically, whereas in Chapter 3 and 4 team-level antecedents were considered antecedents of team resilience, in Chapter 6 a multilevel approach was taken into account, and team-level antecedents were considered antecedents of individual resilience.

Overall, the findings of the current dissertation highlight some prominent factors to enhance the increase in resilience in the organizational context, taking into account its conceptualization at the different levels of analysis stressed in Challenge 1. In doing so, we expand the knowledge about how to boost resilience for the significant constituents of the organizational context, and offer a wide set of suggestions to practitioners.

CHALLENGE 3. What is the real impact of resilience in the organizational context? Does it count in order to achieve better performance?

In trying to address the last of our challenges, we were guided by previous resilience literature about the outcomes of resilience, particularly referring to significant results for the organizational context. In this regard, alongside all the studies that make up this dissertation, we considered performance as the main indicator of positive outcomes. Whenever possible, due to the characteristics of the study or of the sample, we used objective (i.e., GPA) or at least supervisor-reported indicators of performance, as well as time lags (i.e., T1 and T2) in order to strengthen the validity of our results.

In accordance with the guidelines stressed throughout the general introduction of this dissertation (Chapter 1), we decided to focus our studies on performance at different levels of analysis, namely individual- and team-level. Thus, the relationship between resilience and performance was addressed at both levels. Specifically, in Chapters 3 and 4 the relationship was examined at the collective level - that is, the team 
one - assuming that team resilience has a positive relationship with team performance because teams which display the ability to thrive in situations of adversity, improvise and adapt to significant change or stress, or just recover from a negative experience, will be less likely to experience the potentially damaging effects of threatening situations, and thus their performance will be higher. Although this relationship, conceptualized at the team level, had already been proposed in the resilience literature, there are few empirical studies focused on team resilience and, to our knowledge, these are the first empirical studies that explored the resilience-performance relationship at the team level.

Needless to say that the resilience-performance relationship at the individual level of analysis has received more attention from both the theoretical and the empirical points of view. Although in the resilience literature the results are mixed, a general consensus exists about the fact that high resilience leads to high performance. Throughout the dissertation, when the relationship between resilience and performance was addressed at the individual level, specifically in Chapters 5 and 6 , we also included satisfaction as an additional indicator of positive outcome. Beyond the value of positive feelings for the individual who composed the organization, the impact and benefits of satisfaction have been stressed in many cases, thereby providing evidence for the pivotal role of job satisfaction in several organizational outcomes. For this reason, satisfaction was taken into account as a supplementary outcome, and its additive role in increasing performance was considered. In particular, in addition to the direct effect from resilience to performance, we also explored whether the relationship can be increased using satisfaction as a mediator.

Thus, two main results of this dissertation need to be highlighted, taking into consideration that each of them was answered in two studies. Our first contribution underlines the idea that a high level of team resilience leads to better team performance, measured as in-role and extra-role - or task and contextual (Goodman \& Svyantek, 1999) - performance. Thus, teams which overcome and thrive in situations of adversity, improvise and adapt to significant change or stress, can achieve higher performance. Although this relationship is often proposed theoretically, to our knowledge, evidence about this relationship was still lacking before the studies were conducted for this dissertation and thus it is especially valuable. Turning our attention to the other main result regarding the outcomes of resilience, our second contribution refers to the results at the individual level. In contrast to previous literature, we found that resilience was not directly related to performance, but that it is instead associated to performance via 
satisfaction. Although further investigation is needed, this result seems to go against the widely acknowledged statement that higher resilience is directly related to better performance at the individual level of analysis.

A number of possible reasons can be put forward to explain this unexpected result. From a theoretical point of view, one possible explanation is that the resilience process is not necessarily directly related to performance, given that its focus is on the adaptive process to adjust and thrive amidst adversity. In this sense, although the adversity could be faced and overcome through the process of resilience, this does not automatically lead to a behavioral outcome such as an increase in performance. Thus, it might be a psychological process engendered by resilience that - through an increase in motivational states (e.g., engagement) or attitudes (e.g., satisfaction) - affects performance. In fact, attitudes, states, and beliefs are more proximal outcomes and they could be better able to predict behaviors, such as performance. Given that empirical evidence about this relationship is still insufficient, additional research needs to be conducted in this direction. Another possible explanation is inferred by the fact that, in our studies, the relationship between resilience and performance was studied over time, whereas the effect of resilience on performance could be immediate. This would be consistent with the results found at the team level; however, it could also be that by including team satisfaction as a mediator between resilience and performance, the relationship would be even stronger. In order to clarify this fundamental issue, the results of which could have an important impact on resilience theory, further research is needed.

Overall, through the results of this dissertation, we have made a significant contribution to the study of the impact of resilience on outcomes from the organizational context, bringing to light new potential avenues of how it affects performance. From our perspective, this point seems particularly enriching for resilience research because some of the theoretically well-established results of resilience can be questioned.

\section{Implications for practice}

This dissertation offers practitioners several implications to guide their work in the field of resilience. In times that are unstable and characterized by stressful and adverse conditions in the organizational context, such as the case nowadays, these streams are particularly relevant and necessary. In doing so, it is important to keep in 
mind that resilience is a multilevel construct, and for this reason interventions do not have to target only the individual level of the organization - individual resilience. Thus, an explicit effort needs to be made to ensure individuals are aware of the broader level of resilience they must also strive to achieve. In this sense, interventions at the group level would also be worthwhile. Therefore, relevant implications for practice that were derived from the empirical studies of this dissertation are summarized below.

Firstly, recognition of the fact that certain types of situational features contribute to the development of resilience and, through this, increase performance should encourage the practitioner to pay closer attention to reinforcing these features. For instance, given the importance of the characteristics of the social environments (i.e., perceptions of social context) as well as the existence of job social resources (i.e., social support climate and team coordination), practitioners can support the engendering or maintenance of a positive social context at work, as well as facilitate or enhance positive relationships and cooperation among organizational members. Specifically, in order to enhance positive perceptions of the social context they should focus on the three main constituents of the organization, namely immediate supervisor, colleagues, and top management. To improve the immediate supervisor's positive perception, interventions may support supervisors in exercising their leadership, for instance through coaching programs aimed at training them. To enhance the positive perception of relationships among colleagues, interventions should promote a prosocial orientation characterized by cooperativeness and sharing, as well as allow the development of strong and stable within-group relationships, thus ensuring feelings of belongingness and trust. Finally, interventions directed toward increasing positive perception of top management should focus on developing its ability to establish the clarity of the mission, transparency in communications, conveyance of equity and trust, and integration among different units. All these interventions, and especially those directed toward enhancing positive perceptions of colleagues, will also revert to growth in job social resources given that they are fundamental to engender a climate of social support and coordination.

Secondly, beyond the value of situational features, it is worth considering the importance of dispositional antecedents of resilience to build it up. In this sense, the results of this dissertation suggest practitioners should focus on enhancing (collective) positive emotions and on supporting the creation or reinforcement of coping strategies that are active and problem-oriented, both behaviorally and cognitively. Regarding 
positive emotions, practitioners should be aware that self-reinforcing spirals between collective emotions and group relationships may substantially influence the affective states within work groups and teams because through mechanisms of affective sharing and affective similarity-attraction, work group members may tend to develop homogenous positive moods and emotions, as well as favorable within-group relationships over time (Walter \& Brunch, 2008). However, self-reinforcing spirals may take the form of either virtuous or vicious circles (Weick, 1979), and for this reason practitioners should be able to effectively examine and guide the affective developments in the groups. For instance, the contextual factors discussed in this paper (i.e., perceptions of social context and job social resources) may offer opportunities to proactively influence and shape the spiraling processes on a positive side. Regarding coping strategies, the results may provide practitioners with an opportunity for several interventions to change undesired ways of coping. For instance, they can provide information regarding which beneficial coping strategies need to be promoted and which coping strategies are detrimental. In doing so, practitioners should discuss the positive and negative aspects of individual coping strategies, and help to choose coping methods that are consistent with adaptive functioning, for example by creating an individualized coping plan (Suldo, Shaunessy, Michalowski, \& Shaffer, 2008).

\section{Limitations and research directions}

The first limitation of this dissertation is that, throughout the four studies, the antecedents of resilience were always measured at the same time of resilience's measure. Although reverse or alternative models constantly showed poorer fits than the hypothesized models, the lack of a time-lag does not allow a casual inference between the predictor and criterion variables to be made, and can lead to tautologies in the interpretation of the findings (Bergh, Hanke, Balkundi, Brown, \& Chen, 2004). For instance, it could be possible that the relationship between resilience and some of its antecedents will be self-reinforcing in the shape of a virtuous spiral over time, as for instance was shown at the individual level between positive emotions and resilience (Fredrickson \& Joiner, 2002). Moreover, this threat to the validity of the results also affects the relationship between resilience and its outcomes (i.e., in- and extra-role performance) in studies 3 and 4. In consequence, in order to reduce ambiguity about causal inference in the results, an imperative for future studies is to strive to collect data at different moments, including time-lags between independent and dependent 
variables. Although the results of this dissertation are valuable and theoretically wellanchored, considering the relationships over time is indispensable to be able to discern the direction of causal inference.

The second limitations concern the biasing effects that methods of measurement may have on the validity of measures, especially referring to assessing two or more constructs with the same method. In this dissertation, this threat to the validity of the results is particularly relevant in study 3 , where all measures were obtained from the same source, at the same time, and with common scale properties (Podsakoff, MacKenzie, \& Podsakoff, 2012). Even though statistical remedies were implemented (i.e., Harman's one-factor test, controlling for the effects of a single unmeasured latent method factor), in subsequent studies procedural remedies were also implemented as suggested by Podsakoff and colleagues (2012) in order to control for different sources of method bias.

Another limitation of this dissertation is due to the lack of information about the role of team satisfaction between team resilience and performance. In fact, given the results found when the resilience-performance relationship was analyzed at the individual level, it would be interesting to examine whether satisfaction works as a mediator - at least partially - also at the team level. Thus, future studies are required to establish whether team satisfaction plays a significant role in the resilience-performance relationship at the team level. Altogether, a look over time at the relationship between resilience and performance at the team level is recommended. In fact, the results found at the individual level refer to data collected at two points in time (i.e., resilience at Time 1 and performance at Time 2), and for this reason they could be different from cross-sectional inference.

Finally, the last limitation involves the convenience sample used in all the studies. Although the sample sizes were quite large and sizeable over the four studies, these samples may not be representative, which may have resulted in biased results for the samples. Therefore, future studies should include respondents from stratified random samples that are representative of the target population. Likewise, collecting and analyzing data from different countries in order to establish the generalizability of the results through cross-cultural studies is considered critical.

To conclude, although several suggestions for future research directions were already presented above, some additional issues that need future attention are raised in the following: 
1. How can process and trait perspectives on resilience - each of which has received considerable support but for which there is little integrative work - be further integrated?

2. Are there any viable alternatives to self-report measures of resilience in the organizational context? How might our knowledge of resilience be informed by alternative measurement methodologies?

3. Researchers are increasingly conceptualizing resilience at different levels of analysis, namely individual, team or work-unit, and organizational. How does the multilevel frame affect our understanding of resilience? How can these different levels be further integrated?

4. Recent evidence reveals some dispositional and situational antecedents of resilience in the organizational context. What other variables could influence the development of resilience in organizations?

5. What organizational practices and strategies best influence resilience?

6. How does the timeframe affect our understanding of the outcomes of resilience? Are there consequences of resilience that are proximal, whereas others are distant?

\section{Concluding remarks}

We believe that this dissertation contributes to the emergent field of literature on resilience in the organizational context by focusing on the salient antecedents and outcomes of resilience at both the individual and team levels. Likewise, we consider that our results have important implications for studying how organizations, as well as the individuals and teams of which they are composed, successfully adjust and thrive amidst adverse conditions. Especially in the current times, characterized by economic crisis and global recession, we believe that our results are extremely beneficial and valuable. 


\section{REFERENCES}

Adger, W. N. (2000). Social and Ecological Resilience: are they related? Progress in Human Geography, 24, 347-364. doi:10.1191/030913200701540465

Adlaf, E. M., Gliksman, L., Demers, A., \& Newton-Taylor, B. (2001). The Prevalence of Elevated Psychological Distress Among Canadian Undergraduates: Findings from the 1998 Canadian Campus Survey. Journal of American College Health, 50(2), 67-72. doi:10.1080/07448480109596009

Ahles, C. B., \& Bosworth, C. C. (2004). The perception and reality of student andworkplace teams. Journalism \& Mass Communication Educator, 59(1), 4159. doi:10.1177/107769580405900108

Ainley, J., Foreman, J., \& Sheret, M. (1991). High School Factors That Influence Students to Remain in School. The Journal of Educational Research, 85(2), 6980. doi:10.1080/00220671.1991.10702816

Ajzen, I., \& Fishbein, M. (2005). The influence of attitudes on behavior. In D. Albarracín, B. T. Johnson, \& M. P. Zanna (Eds.), The handbook of attitudes (pp. 173-221). Mahwah, NJ: Erlbaum.

Algoe, S. B., \& Fredrickson, B. L. (2011). Emotional Fitness and the Movement of Affective Science From Lab to Field. American Psychologist, 66(1), 35-42. doi: $10.1037 / \mathrm{a} 0021720$

Alva, S. A. (1991). Academic Invulnerability among Mexican-American Students: The Importance of Protective Resources and Appraisals. Hispanic Journal of Behavioral Sciences, 13(1), 18-34. doi:10.1177/07399863910131002

American Psychological Association (2009). Resilience. Recuperado 16/07/2013, de http://www.apa.org/practice/programs/campaign/resilience.aspx

Appelbaum, S. H. \& Gallagher, J. (2000). The Competitive Advantage of Organizational Learning. Journal of Workplace Learning, 12(2), 40-56. doi:10.1108/13665620010316000

Arbuckle, J. L. (2005). Amos 6.0 User's Guide. Chicago, IL: SPSS Inc.

Arbuckle, J. L. (2010). IBM SPSS Amos 19 Users' guide. Chicago, IL: SPSS.

Argyris, C. (1993). On Organizational Learning. Blackwell Publishers. USA. 
Avey, J. B., Luthans, F., \& Jensen, S. M. (2009). Psychological capital: a positive resource for combating employee stress and turnover. Human Resource Management, 48(5), 677-693. doi:10.1002/hrm.20294

Avey, J. B., Luthans, F., \& Youssef, C. M. (2010). The Additive Value of Positive Psychological Capital in Predicting Work Attitudes and Behaviors. Journal of Management, 36(2), 430-452. doi:10.1177/0149206308329961

Baker, J. A., Dilly, L. J., Aupperlee, J. L., \& Patil, S. A. (2003). The developmental context of school satisfaction: Schools as psychologically healthy environments. School Psychology Quarterly, 18(2), 206-221. doi:10.1521/scpq.18.2.206.21861

Bakker, A. B. (2010). Engagement and 'job crafting': engaged employees create their own great place to work. In Albrecht, S. L. (Ed.), Handbook of Employee Engagement Perspectives, Issues, Research and Practice (pp. 229-244), New Horizons in Management.

Bakker, A. B., \& Demerouti, E. (2007). The job demands-resources model: State of the art. Journal of Managerial Psychology, 22, 309-328. doi:10.1108/02683940710733115

Bales, R. F. (1950). Interaction process analysis: A method for the study of small groups. Reading, MA: Addison-Wesley.

Bandura, A. (1997). Self-Efficacy. The exercise of control. Nueva Jersey: Freeman.

Bandura, A. (1998). Personal and collective efficacy in human adaptation and change. In Adair, J.G., Belanger, D. \& Dion, K. L. (Eds.), Advances in psychological science, Vol 1: personal, social and cultural aspects (pp. 51-71). Hove, UK: Psychology Press.

Bandura, A. (2000). Exercise of Human Agency Through Collective Efficacy. Current Directions in Psychological Science, 9(3), 75-78. doi:10.1111/1467-8721.00064

Bandura, A. (2011). A Social Cognitive perspective on Positive Psychology. Revista de Psicología Social, 26(1), 7-20. doi:10.1174/021347411794078444

Baron, R. M., \& Kenny, D. A. (1986). The Moderator-mediator variable distinction in social psychological research: Conceptual, strategic and statistical considerations. Journal of Personality and Social Psychology, 51, 1173-1182. doi:10.1037/00223514.51.6.1173 
Barsade, S. G. (2002). The Ripple Effect: Emotional Contagion and Its Influence on Group Behavior. Administrative Science Quarterly, 47(4), 644. doi:10.2307/3094912

Bartel, C. A., \& Saavedra, R. (2000). The collective construction of work group mood. Administrative Science Quarterly, 45, 197-231. doi:10.2307/2667070

Beehr, T. A., Walsh, J. T., \& Taber, T. D. (1976). Relationship of stress to individually and organizationally valued states: Higher order needs as a moderator. Journal of Applied Psychology, 61, 41-47. doi:10.1037/0021-9010.61.1.41

Belanger, F., Lewis, T., Kasper, G. M., Smith, W. J., \& Harrington, K. V. (n.d.). Are Computing Students Different? An Analysis of Coping Strategies and Emotional Intelligence. IEEE Transactions on Education, 50(3), 188-196. doi:10.1109/te.2007.900029

Bennett, J. B., Aden, C. A., Broome, K., Mitchell, K., \& Rigdon, W. D. (2010). Team Resilience for Young Restaurant Workers: Research-to-Practice Adaptation and Assessment. Journal Of Occupational Health Psychology, 15(3), 223-236. doi:10.1037/a0019379

Bergh, D. D., Hanke, R., Balkundi, P., Brown, M., \& Chen, X. (2004). An assessment of research designs in strategic management research: the frequency of threats to internal validity. Research Methodology in Strategy and Management, 347-363. doi:10.1016/s1479-8387(04)01112-9

Beyerlein, M. M. E., Johnson, D. A. E., \& Beyerlein, S. T. E. (1995). Advances in interdisciplinary studies of work teams: Knowledge work in teams (XIX ed., Vol. 2). Stanford, CT: JAI Press, Inc.

Bliese, P.D. (2000). Within-group agreement, non-independence, and reliability: Implications for data aggregation and analysis. In K. J. Klein, S. W. Kozlowski (Eds.), Multilevel theory, research, and methods in organizations (pp. 349-381). San Francisco, CA US: Jossey-Bass.

Block, J. H., \& Block, J. (1980). The role of ego-control and ego-resiliency in the origination of behavior. In W. A. Collings (Ed.), (Vol. 13, pp. 39-101). Hillsdale, NJ: Erlbaum. 
Bommer, W. H., Johnson, J. L., Rich, G. A., Podsakoff, P. M., \& Mackenzie, S. B. (1995). On the interchangeability of objective and subjective measures of employee performance: a meta-analysis. Personnel Psychology, 48(3), 587-605. doi:10.1111/j.1744-6570.1995.tb01772.x

Bonanno, G.A. (2004). Loss, trauma, and human resilience: Have we underestimated the human capacity to thrive after extremely aversive events? American Psychologist, 59(1), 20-28. doi:10.1037/0003-066x.59.1.20

Bonanno, G. A., Noll, J. G., Putnam, F. W., O’Neill, M., \& Trickett, P. K. (2003). Predicting the Willingness to Disclose Childhood Sexual Abuse from Measures of Repressive Coping and Dissociative Tendencies. Child Maltreat, 8(4), 302-318. doi:10.1177/1077559503257066

Boone, C., van Olffen, W., van Witteloostuijn, A., \& de Brabander, B. (2004). The genesis of top management team diversity: Selective turnover among top management teams in Dutch newspaper publishing 1970-94. Academy of Management Journal, 47(5), 633-656. doi:10.2307/20159609

Borgogni, L., Dello Russo, S., Di Tecco, C., Alessandri, G., \& Vecchione, M. (2011, August). Social cognitive theory as reference frame for perceptions of context. Paper presented at the Annual Meeting of the Academy of Management, San Antonio, Texas.

Borgogni, L., Dello Russo, S., \& Latham, G. (2011). The Relationship of Employee Perceptions of the Immediate Supervisor and Top Management with Collective Efficacy. Journal of Leadership \& Organizational Studies, 18(1), 5-13. doi:10.1177/1548051810379799

Borgogni, L., Dello Russo, S., Petitta, L., \& Vecchione, M. (2010). Predicting job satisfaction and job performance in a privatized organization. International Public Management Journal, 13(3), 275-296. doi:10.1080/10967494.2010.504114

Borgogni, L., Petitta, L., \& Mastrorilli, A. (2010). Correlates of Collective Efficacy in the Italian Air Force. Applied Psychology: An International Review, 59(3), 515537. doi:10.1111/j.1464-0597.2009.00410.x 
Borman, W. C., \& Motowidlo, S. J. (1993). Expanding the criterion domain to include elements of contextual performance. In Schmidt N., Borman W. C., Howard A., Kraut A., Ilgen D., Schneider B., \& Zedeck S. (Eds.), Personnel selection in organizations (pp. 71-98). San Francisco: Jossey-Bass.

Brown, T. A. (2006). Confirmatory factor analysis for applied research. New York, NY US: Guilford Press.

Brown, W. (2005). The new employment contract and the "at risk" worker. Journal of Business Ethics, 58, 195-201. doi:10.1007/s10551-005-1414-7

Browne, M. W., \& Cudeck, R. (1993). Alternative ways of assessing model filt. In K. A. Bollen \& J. S. Long (Eds.), Testing structural equations models (pp. 136-162). Newbury Park, CA: Sage.

Bryk, A. S., \& Raudenbush, S. W. (1992). Hierarchical linear models: Applications and data analysis. Newbury Park, CA: Sage.

Burke, M. J., \& Dunlap, W. P. (2002). Estimating Interrater Agreement with the Average Deviation Index: A User's Guide. Organizational Research Methods, 5(2), 159-172.

Burke, N. J., Finkelstein, L. M., \& Dusig, M. S. (1999). On average deviation indices for estimating interrater agreement. Organizational Research Methods, 2, 49-68. doi:10.1177/109442819921004

Byrne, M., \& Flood, B. (2003). Assessing the Teaching Quality of Accounting Programmes: An evaluation of the Course Experience Questionnaire. Assessment \& Evaluation in Higher Education, 28(2), 135-145. doi:10.1080/02602930301668

Cable, D., \& Judge, T. A. (1997). Interviewers' perceptions of person-organization fit and organizational selection decisions. Journal of Applied Psychology, 82, 546561. doi:10.1037//0021-9010.82.4.546

Cable, D. M., \& Parsons, C. (2001). Socialization tactics and person-organization fit. Personnel Psychology, 54, 1-22. doi:10.1111/j.1744-6570.2001.tb00083.x

Campbell-Sills, L., Cohan, S.L., \& Stein, M.B. (2006). Relationship of resilience to personality, coping, and psychiatric symptoms in young adults. Behaviour Research and Therapy, 44(4), 585-599. doi:10.1016/j.brat.2005.05.001 
Cameron, K. S. (1998). Strategic organizational downsizing: An extreme case. Research in Organizational Behavior, 20, 185-229.

Carmeli, A., Friedman, Y., \& Tishler, A. (2013). Cultivating a resilient top management team: The importance of relational connections and strategic decision comprehensiveness. Safety Science, 51(1), 148-159. doi:10.1016/j.ssci.2012.06.002

Carthey, J., De Leval, M. R. \& Reason, J. T. (2001). Institutional resilience in healthcare systems. Quality in health care, 10(1), 29-32. doi:10.1136/qhc.10.1.29

Carver, C. S. (2003). Pleasure as a sign you can attend to something else: Placing positive feelings within a general model of affect. Cognition and Emotion, 17(2), 241-261. doi:10.1080/02699930302294

Carver, C. S., Scheier, M. F., \& Weintraub, J. K. (1989). Assessing coping strategies: A theoretically based approach. Journal of Personality and Social Psychology, 56(2), 267-283. doi:10.1037/0022-3514.56.2.267

Chambel, M. J., \& Curral, L. (2005). Stress in Academic Life: Work Characteristics as Predictors of Student Well-being and Performance. Applied Psychology, 54(1), 135-147. doi:10.1111/j.1464-0597.2005.00200.x

Chan, D. (1998). Functional relations among constructs in the same content domain at different levels of analysis: A typology of composition models. Journal of Applied Psychology, 83(2), 234-246. doi:10.1037/0021-9010.83.2.234

Choi, J. N., Sung, S. Y. \& Kim, M. U. (2010). How Do Groups React to Unexpected Threats? Crisis Management in Organizational Teams. Social Behavior and Personality: an international journal, 38(6), 805-828. doi:10.2224/sbp.2010.38.6.805

Clauss-Ehlers, C. S. (2008). Sociocultural factors, resilience, and coping: Support for a culturally sensitive measure of resilience. Journal of Applied Developmental Psychology, 29(3), 197-212. doi:10.1016/j.appdev.2008.02.004

Cohn, M. A., Fredrickson, B. L., Brown, S. L., Mikels, J. A., \& Conway, A. M. (2009). Happiness unpacked: positive emotions increase life satisfaction by building resilience. Emotion Washington Dc, 9(3), 361-368. doi:10.1037/a0015952 
Collins, S. (2008). Statutory Social Workers: Stress, Job Satisfaction, Coping, Social Support and Individual Differences. British Journal of Social Work, 38(6), 11731193. doi:10.1093/bjsw/bcm047

Conger, J. A., Kanungo, R. N., \& Menon, S. T. (2000). Charismatic leadership and follower effects. Journal of Organizational Behavior, 21(7), 747-767. doi: 10.1002/1099-1379(200011)21:7<747::aid-job46>3.3.co;2-a

Connor, K. M., \& Davidson, J. T. (2003). Development of a new resilience scale: The Connor-Davidson Resilience Scale (CD-RISC). Depression and Anxiety, 18(2), 76-82. doi:10.1002/da.10113

Cortina, J. M., Chen, G., \& Dunlap, W. P. (2001). Testing interaction effects in LISREL: Examination and illustration of available procedures. Organizational Research Methods, 4, 324-360. doi:10.1177/109442810144002

Costarelli, S. (2009). Intergroup threat and experienced affect: The distinct roles of causal attributions and in-group identification. Journal of Social Psychology, 149(3), 293-301. doi:10.3200/socp.149.3.393-401

Costello, A. B., \& Osborne, J. W. (2005). Best practices in exploratory factor analysis: Four recommendations for getting the most from your analysis. Practical Assessment Research \& Evaluation, 10(7).

Cotton, S., Dollard, M., \& De Jonge, J. (2002). Stress and student job design: Satisfaction, well-being, and performance in university students. International Journal of Stress Management, 9, 147-162. doi:10.1023/a:1015515714410

Coutu, D. L. (2002). How Resilience Works. Harvard Business Review, 80(5), 46-51.

Crawford, E. R., LePine, J. A., \& Rich, B. (2010). Linking job demands and resources to employee engagement and burnout: A theoretical extension and meta-analytic test. Journal of Applied Psychology, 95(5), 834-848. doi:10.1037/a0019364

Dao, T. K., Lee, D., \& Chang, H. L. (2007). Acculturation level, perceived English fluency, perceived social support level, and depression among Taiwanese international students. College Student Journal, 41, 287-295.

Day, D. V. (2000). Leadership development: A review in context. The Leadership Quarterly, 11, 581-613. doi:10.1016/s1048-9843(00)00061-8 
De Lange, A. H., Taris, T. W., Kompier, M. A. J., Houtman, I. L. D., \& Bongers, P. M. (2004). The relationships between work characteristics and mental health: examining normal, reversed and reciprocal relationships in a 4-wave study. Work \& Stress, 18(2), 149-166. doi:10.1080/02678370412331270860

Demerouti, E., Bakker, A. B., Nachreiner, F., \& Schaufeli, W. (2001). The job demands-resources model of burnout. Journal of Applied Psychology, 86(3), 499512. doi:10.1037/0021-9010.86.3.499

Demos, E. V. (1989). Resiliency in infancy. In T. F. Dugan \& R. Cole (Eds.), The child of our times: Studies in the development of resiliency (pp. 3-22). Philadelphia: Brunner/Mazel.

Diamond, M. A. (1996). Innovation and Diffusion of Technology. A Human Process. Consulting Psychology Journal: Practice and Research, 48(4), 221-229. doi:10.1037/1061-4087.48.4.221

Dolbier, C. L., Jaggars, S. S., \& Steinhardt, M. A. (2010). Stress-related growth: preintervention correlates and change following a resilience intervention. Stress and Health, 26(2), 135-147. doi:10.1002/smi.1275

Doll, B., \& Lyon, M. A, (1998). Risk and resilience: Implications for the delivery of educational and mental health services in schools. School Psychology Review, 27, $348-363$.

Driskell, J. E., \& Salas, E. (1991). Group decision making under stress. Journal of Applied Psychology, 76(3), 473-478. doi:10.1037/0021-9010.76.3.473

Edmondson, A. C., Bohmer, R. M., \& Pisano, G. P. (2001). Disrupted routines: Team learning and new technology implementation in hospitals. Administrative Science Quarterly, 46(4), 685. doi:10.2307/3094828

Edwards, J. R., \& Cable, D.M. (2009). The Value of Value Congruence. Journal of Applied Psychology, 94(3), 654-677. doi:10.1037/a0014891

Edwards, J. R., \& Lambert, L. S. (2007). Methods for integrating Moderation and Mediation: A general analytical framework using Moderated path analysis. Psychological Methods, 12(1), 1-22. doi:10.1037/1082-989x.12.1.1

Egeland, B., Carlson, E., \& Sroufe, L. A. (1993). Resilience as process. Development and Psychopathology, 5(4), 517-528. doi:10.1017/s0954579400006131 
Eurofound (2012). Fifth European Working Conditions Survey. Publications Office of the European Union, Luxembourg. doi:10.2806/34660

European Agency for Safety and Health at Work (2010). European Survey of Enterprises on New and Emerging Risks. Managing safety and health at work. https://osha.europa.eu/en/publications/ reports/esener1_osh_management. Accessed 15 June 2013.

European Foundation for the Improvement of Living and Working Conditions (2013). Impact of the crisis on working conditions in Europe. http://www.eurofound.europa.eu/ewco/studies/tn1212025s/tn1212025s_1.htm.

Accessed 15 May 2014.

Fergusson, D. M., Beautrais, A. L., \& Horwood, L. J. (2003). Vulnerability and resiliency to suicidal behaviours in young people. Psychological Medicine, 33(1). doi:10.1017/s0033291702006748

Fernández-Ballesteros, R., Díez-Nicolás, J., Caprara, G., Barbaranelli, C., \& Bandura, A. (2002). Determinants and Structural Relation of Personal Efficacy to Collective Efficacy. Applied Psychology: An International Review, 51(1), 107125. doi:10.1111/1464-0597.00081

Finn, J. D., \& Rock, D. A. (1997). Academic success among students at risk for school failure. Journal of Applied Psychology, 82(2), 221-234. doi:10.1037/00219010.82.2.221

Fishbein, M., \& Ajzen, I. (1974). Attitudes towards objects as predictors of single and multiple behavioral criteria. Psychological Review, 81(1), 59-74. doi:10.1037/h0035872

Fiske, S. T. (2004). Social Beings: A Core Motives Approach to Social Psychology. New York: Wiley.

Flanagan, J. C. (1954). The critical incident technique. Psychological Bulletin, 51(4), 327-358. doi:10.1037/h0061470

Fleig-Palmer, M. M., Luthans, K. W., \& Mandernach, B. J. (2009). Successful Reemployment Through Resiliency Development. Journal of Career Development, 35(3), 228-247. doi:10.1177/0894845308327271 
Fletcher, D., \& Sarkar, M. (2013). Psychological Resilience. European Psychologist, 18(1), 12-23. doi:10.1027/1016-9040/a000124

Folkman, S. (2008). The case for positive emotions in the stress process. Anxiety, Stress \& Coping: An International Journal, 21(1), 3-14. doi:10.1080/10615800701740457

Folkman, S., \& Lazarus, R.S. (1980). An analysis of coping in a middle-aged community sample. Journal of Health and Social Behavior, 21(3), 219. doi: $10.2307 / 2136617$

Folkman, S., \& Moskowitz, J. T. (2004). Coping: Pitfalls and Promise. Annual Review of Psychology, 55(1), 745-774. doi:10.1146/annurev.psych.55.090902.141456

Fornell, C., \& Larcker, D. F. (1981). Evaluating Structural Equation Models with Unobservable Variables and Measurement Error. Journal of Marketing Research, 18(1), 39. doi:10.2307/3151312

Fredrickson, B. L. (1998). What good are positive emotions? Review of General Psychology, 2, 300-319. doi:10.1037/1089-2680.2.3.300

Fredrickson, B. L. (2001). The role of positive emotions in positive psychology: The broaden-and-build theory of positive emotions. American Psychologist: Special Issue 56, 218-226. doi:10.1037/0003-066x.56.3.218

Fredrickson, B. L., \& Cohn, M. A. (2008). Positive emotions. In M. Lewis, J. Haviland \& L. F. Barrett (Eds.), Handbook of emotions (3rd ed.). New York: Guilford Press.

Fredrickson, B. L., \& Joiner, T. (2002). Positive Emotions Trigger Upward Spirals Toward Emotional Well-Being. Psychological Science, 13(2), 172. doi:10.1111/1467-9280.00431

Fredrickson, B. L., \& Losada, M. F. (2005). Positive Affect and the Complex Dynamics of Human Flourishing. American Psychologist, 60(7), 678-686. doi:10.1037/0003-066X.60.7.678

Fredrickson, B. L., Tugade, M. M., Waugh, C. E., \& Larkin, G. R. (2003). What Good Are Positive Emotions in Crises? A Prospective Study of Resilience and Emotions Following the Terrorist Attacks on the United States on September 11th, 2001. 
Journal of Personality \& Social Psychology, 84(2), 365-376. doi:10.1037/00223514.84.2.365

Gable, S. L., \& Haidt, J. (2005). What (and why) is positive psychology? Review of General Psychology, 9, 103-110. doi:10.1037/1089-2680.9.2.103

Ganor, M., \& Ben-Lavy, Y. (2003). Community resilience: Lessons derived from Gilo under fire. Journal of Jewish Communal Service, 105-108.

Garmezy, N. (1971). Vulnerability research and the issue of primary prevention. American Journal of Orthopsychiatry, 41, 101-116. doi:10.1111/j.19390025.1971.tb01111.x

Garmezy, N. (1974). Children at risk: The search for the antecedents of schizophrenia. Schizophrenia Bulletin, 8, 14-90. doi:10.1093/schbul/1.8.14

George, J. M. (1990). Personality, affect, and behavior in groups. Journal of Applied Psychology, 75, 107-116. doi:10.1037/0021-9010.75.2.107

Gil, F., Alcover, C. M., \& Peiró, J. M. (2005). Work team effectiveness in organizational contexts: Recent research and applications in Spain and Portugal. Journal of Managerial Psychology, 20(3/4), 193-218. doi:10.1108/02683940510589000

Gittel, J.H., Cameron, K., Lim, S., \& Rivas, V. (2006). Relationship, layoff, and organizational resilience. Airline industry responses to September 11. The Journal of applied behavioral science, 42(3), 300-329. doi:10.1177/0021886306286466

Goodman, S. A., \& Svyantek, D. (1999). Person-Organization fit and contextual performance: Do shared values matter. Journal of Vocational Behavior, 55, 254275. doi:10.1006/jvbe.1998.1682

Grant, L., \& Kinman, G. (2012). Enhancing Wellbeing in Social Work Students: Building Resilience in theNext Generation. Social Work Education, 31(5), 605621. doi:10.1080/02615479.2011.590931

Greene, R. R. (2002). Human behavior theory: A resilience orientation. In R. R. Greene (Ed.), Resiliency: An integrated approach lo practice, policy, and research (pp. 1-27). Washington, DC: NASW. 
Gruman, J. A., \& Saks, A. M. (2011). Performance management and employee engagement. Human Resource Management Review, 21(2), 123-136. doi:10.1016/j.hrmr.2010.09.004

Gully, S. M., Incalcaterra, K. A., Joshi, A., \& Beaubien, J. (2002). A Meta-Analysis of Team-Efficacy, Potency, and Performance: Interdependence and Level of Analysis as Moderators of Observed Relationships. Journal of Applied Psychology, 87(5), 819-832. doi:10.1037//0021.9010.87.5.819

Hamel, G. \& Välikangas, L. (2003). The quest for resilience. Harvard Business Review, $81,52-63$.

Harter, J., Schmidt, F., \& Keyes, C. (2003). Well-being in the workplace and its relationship to business outcomes: A review of the Gallup studies. In C. Keyes \& J. Haidt (Eds.), Flourishing: Positive psychology and the life well lived (pp. 205224). Washington, DC: American Psychological Association.

Hatfield, E., Cacioppo, J. T., \& Rapson, R. L. (1992). Primitive emotional contagion. In M. S. Clark (Ed.), Emotion and social behavior (pp. 151-177). Newbury Park, CA: Sage.

Hind, P., Frost, M., \& Rowley, S. (1996). The resilience audit and the psychological contract. Journal of Managerial Psychology, 11(7), 18-29. doi:10.1108/02683949610148838

Hirsch, J. K., \& Ellis, J. B. (1996). Differences in life stress and reasons for living among college suicide ideators and non-ideators. College Student Journal, 30, 377-384.

Ho, V. T., \& Gupta, N. (2014). Retaliating against Customer Interpersonal Injustice in a Singaporean Context: Moderating Roles of Self-Efficacy and Social Support. Applied Psychology, 63(3), 383-410. doi:10.1111/j.1464-0597.2012.00529.x

Hobfoll, S. E. (1989). Conservation of resources: A new attempt at conceptualizing stress. American Psychologist, 44(3), 513-524. doi:10.1037/0003-066x.44.3.513

Hobfoll, S. E. (2001). The influence of culture, community, and the nested-self in the stress process: advancing conservation of resources theory. Applied Psychology: An International Review, 50(3), 337-421. doi:10.1111/1464-0597.00062. 
Hobfoll, S. E. (2002). Social and psychological resources and adaptation. Review of General Psychology, 6(4), 307-324. doi:10.1037/1089-2680.6.4.307

Hobfoll, S. E. (2011). Conservation of resource caravans and engaged settings. Journal of Occupational and Organizational Psychology, 84(1), 116-122. doi:10.1111/j.2044-8325.2010.02016.x

Hockey, G. R. J. (1997). Compensatory control in the regulation of human performance under stress and high workload: A cognitive-energetical framework. Biological Psychology, 45, 73-93. doi:10.1016/s0301-0511(96)05223-4

Hoffman, M. L. (1985). Interaction of affect and cognition in empathy. In C. E. Izard, J. Kagan, \& R. B. Zajonc (Eds.), Emotions, cognition, and behavior (pp. 103-131). New York: Cambridge University Press.

Hofmann, D. A., \& Gavin, M. B. (1998). Centering Decisions in Hierarchical Linear Models: Implications for Research in Organizations. Journal of Management, 24(5), 623-641. doi:10.1177/014920639802400504

Hofmann, D.A., Griffin, M.A., \& Gavin, M.B. (2000). The application of hierarchical linear modeling to organizational research. In K. J. Klein and S. W. J. Kozlowski (eds.), Multilevel Theory, Research, and Methods in Organizations: 467-511. San Francisco: Jossey-Bass.

Holling, C. S. (1996). Engineering Resilience vs. Ecological Resilience. Engineering Within Ecological Constraints. P. C. Schulze. Washington DC, National Academy: 31-43.

Horne, J. F. I. \& Orr, J. E. (1998). Assessing behaviors that create resilient organizations. Employment Relations Today, 24(4), 29-39. doi:10.1002/ert.3910240405

Houghton, J. D., Wu, J. P., Jeffrey, L. G., Christopher, P. N., \& Charles, C. M. (2012). Effective stress management. Journal of Management Education, 36, 220-238. doi:10.1177/1052562911430205

Hox, J. J. (2002). Multilevel analysis: Techniques and applications. Mahwah, NJ: Lawrence Erlbaum Associates. 
Hu, L., \& Bentler, P. M. (1999). Cutoff criteria for fit indexes in covariance structure analysis: Conventional criteria versus new alternatives. Structural Equation Modeling, 6(1), 1-55. doi:10.1080/10705519909540118

Hunter, A. J., \& Chandler, G. E. (1999). Adolescent resilience. Image: Journal of Nursing Scholarship, 31(3), 243-247. doi:10.1111/j.1547-5069.1999.tb00488.x

Isen, A. M. (2000). Positive affect and decision making. In M. Lewis \& J. M. HavilandJones (Eds.), Handbook of emotions (2nd ed., pp. 417-435). New York: Guilford Press.

Jöreskog, K. G., \& Sörbom, D. (1993). LISREL 8: Structural equation modeling with the SIMPLIS command language. Chicago: Scientific Software International.

Jöreskog, K. G., \& Sörbom, D. (2006). LISREL 8.80. Lincolnwood, IL:Scientific Software Intemational, Inc.

Judge, T. A., Bono, J. E., \& Locke, E. A. (2000). Personality and Job Satisfaction: The Mediating Role of Job Characteristics. Journal of Applied Psychology, 85(2), 237-249. doi:10.1037/0021-9010.85.2.237

Judge, T. A., Bono, J. E., Thoresen, C. J., \& Patton, G. K. (2001). The Job SatisfactionJob Performance Relationship: A Qualitative and Quantitative Review. Psychological Bulletin, 127(3), 376-407. doi:10.1037/0033-2909.127.3.376

Judge, T. A., \& Kammeyer-Mueller, J. D. (2012). Job Attitudes. Annual Review of Psychology, 63(1), 341-367. doi:10.1146/annurev-psych-120710-100511

Judge, T. A., Locke, E. A., Durham, C. C., \&Kluger, A. N. (1998). Dispositional Effects on Job and Life Satisfaction: The Role of Core Evaluations. Journal of Applied Psychology, 83(1), 17-34. doi:10.1037/0021-9010.83.1.17

Judge, T. A., \& Watanabe, S. (1993). Another Look at the Job Satisfaction - Life Satisfaction Relationship. Journal of Applied Psychology, 78(6), 939-948. doi:10.5465/ambpp.1993.10317003

Kahn, W. A. (2005). Holding fast: The struggle to create resilient caregiving organizations. New York, NY: Brunner-Routledge.

Kaplan, S., LaPort, K. \& Waller, M. J. (2013). The role of positive affectivity in team effectiveness during crises. Journal of Organizational Behavior, 34(4), 473-491. doi: 10.1002/job.1817 
Kenny, D. A., Kashy, D. A., \& Bolger, N. (1998). Data analysis in social psychology. In D. Gilbert, S. T. Fiske, \& G. Lindzey (Eds.), Handbook of social psychology (Vol. 1, pp. 233-265). New York: McGraw-Hill.

Kenny, D. A., \& LaVoie, L. (1985). Separating individual and group effects. Journal of Personality and Social Psychology, 48(2), 339-348. doi:10.1037/00223514.48.2.339

Kline, R. B. (2011). Principles and Practice of Structural Equation Modeling. The Guilford Press; 3rdEdition.

Klein, K. J., Conn, A., Smith, D., \& Sorra, J. (2001). Is Everyone in Agreement? An Exploration of Within-Group Agreement in Employee Perceptions of the Work Environment. Journal of Applied Psychology, 86(1), 3-16. doi:10.1037/00219010.86 .1 .3

Kobasa, S. C., Maddi, S. R., \& Kahn, S. (1982). Hardiness and health: A prospective study. Journal of Personality and Social Psychology, 42(1), 168-177. doi:10.1037/0022-3514.42.1.168

Kozlowski, S. W. J., \& Bell, B. S. (2003). Work Groups and Teams in Organizations. Handbook of Psychology. doi:10.1002/0471264385.wei1214

Kozlowski, S. J., \& Hattrup, K. (1992). A Disagreement About Within-Group Agreement: Disentangling Issues of Consistency Versus Consensus. Journal of Applied Psychology, 77(2), 161-167. doi:10.1037/0021-9010.77.2.161

Kozlowski, S. J., \& Ilgen, D. R. (2006). Enhancing the Effectiveness of Work Groups and Teams. Psychological Science in The Public Interest (Wiley-Blackwell), 7(3), 77-124. doi:10.1111/j.1529-1006.2006.00030.x

Kuchinke, K. P. (1995). Managing learning for performance. Human Resource Development Quarterly, 6(3), 306-316. doi:10.1002/hrdq.3920060309

Kumpfer, K. L. (1999). Factors and processes contributing to resilience: The resilience framework. In M. D. Glantz \& J. L. Johnson (Eds.), Resilience and development: Positive life adaptations (pp. 179-224). New York: Kluwer Academic/Plenum.

Kunin, T. (1955). The construction of a new type of attitude measure. Personnel Psychology, 8, 65-67. doi:10.1111/j.1744-6570.1955.tb01189.x 
Kwok, O. M., Hughes, J. N., \& Wen, L. (2007). Role of resilient personality on lower achieving first grade students' current and future achievement. Journal of School Psychology, 45(1), 61-82. doi:10.1016/j.jsp.2006.07.002

Larson, M., \& Luthans, F. (2006). Potential Added Value of Psychological Capital in Predicting Work Attitudes. Journal of Leadership \& Organizational Studies, 13(1), 45-62. doi:10.1177/10717919070130010701

Lazarus, R. S., \& Folkman, S. (1984). Stress, appraisal, and coping. New York: Springer Publishing.

Leary, K. A., \& De Rosier, M. E. (2012). Factors Promoting Positive Adaptation and Resilience during the T6ransition to College. Psychology, 3(12), 1215-1222. doi:10.4236/psych.2012.312a180

Leipold, B., \& Greve, W. (2009). Resilience. European Psychologist, 14(1), 40-50. doi:10.1027/1016-9040.14.1.40

Lengnick-Hall, C. A. \& Beck, T. E. (2003). Beyond bouncing back: The concept of organizational resilience. Seattle, WA: Paper presented at the National Academy of Management meetings.

Lengnick-Hall, C. A., Beck, T. E., \& Lengnick-Hall, M. L. (2011). Developing a capacity for organizational resilience through strategic human resource management. Human Resource Management Review, 21, 243-255. doi:10.1016/j.hrmr.2010.07.001

Lim, V. K. G. (1996). Job Insecurity and Its Outcomes: Moderating Effects of WorkBased and Nonwork-Based Social Support. Human Relations, 49(2), 171-194. doi:10.1177/001872679604900203

Lindebaum, D., \& Jordan, P. J. (2012). Relevant but exaggerated: the effects of emotional intelligence on project manager performance in construction. Construction Management \& Economics, 30(7), 575-583. doi:10.1080/01446193.2011.593184

Linnenluecke, M., \& Griffiths, A. (2010). Beyond Adaptation: Resilience for Business in Light of Climate Change and Weather Extremes. Business and Society, 49(3), 477-511. doi:10.1177/0007650310368814 
Liossis, P. L., Shochet, I. M., Millear, P. M., \& Biggs, H. (2009). The Promoting Adult Resilience (PAR) Program: The Effectiveness of the Second, Shorter Pilot of a Workplace Prevention Program. Behaviour Change, 26(2), 97-112. doi:10.1375/bech.26.2.97

Loh, J. M. I., Schutte, N. S., \& Thorsteinsson, E. B. (2014). Be Happy: The Role of Resilience Between Characteristic Affect and Symptoms of Depression. Journal of Happiness Studies. doi: 10.1007/s10902-013-9467-2

Longstaff, P. (2005). Security, resilience, and communication in unpredictable environments such as terrorism, natural disasters and complex technology. Harvard University, Cambridge, MA.

Luthans, F., Avolio, B. J., Avey, J. B., \& Norman, S. M. (2007). Positive Psychological Capital: Measurement and Relationship With Performance and Satisfaction. Personnel Psychology, 60(3), 541-572. doi:10.1111/j.1744-6570.2007.00083.x

Luthans, F., Avey, J. B., Smith, R. C., \& Li, W. (2008).More evidence on the value of Chinese workers' psychological capital: A potentially unlimited competitive resource? The International Journal of Human Resource Management, 19(5), 818-827. doi: 10.1080/09585190801991194

Luthans, F., Avolio, B. J., Walumbwa, F. O., \& Li, W. (2005). The psychological capital of Chinese workers: Exploring the relationship with performance. Management and Organization Review, 1(2), 247-269. doi:10.1111/j.17408784.2005.00011.x

Luthans, F., Norman, S. M., Avolio, B. J., \& Avey, J. B. (2008). The mediating role of psychological capital in the supportive organizational climate-employee performance relationship. Journal of Organizational Behavior, 29(2), 219-238. doi:10.1002/job.507

Luthans, F., Vogelgesang, G. R., \& Lester, P. B. (2006). Developing the Psychological Capital of Resiliency. Human Resource Development Review, 5(1), 25-44. doi:10.1177/1534484305285335

Luthans, F., Youssef, C. M., \& Avolio, B. J. (2007). Psychological capital. New York, NY: Oxford University Press.

Luthans, F., Youssef, C. M., Sweetman, D. S., \& Harms, P. D. (2013). Meeting the Leadership Challenge of Employee Well-Being Through Relationship PsyCap 
and Health PsyCap. Journal of Leadership \& Organizational Studies, 20(1), 118133. doi:10.1177/1548051812465893

Luthar, S. S. (1991). Vulnerability and resilience: A study of high-risk adolescents. Child Development, 62(3), 600-616. doi:10.2307/1131134

Luthar, S. S., Cicchetti, D., \& Becker, B. (2000). The construct of resilience: A critical evaluation and guidelines for future work. Child Development, 71, 543-562. doi:10.1111/1467-8624.00164

MacKinnon, D. P., Fairchild, A. J., \& Fritz, M. S. (2007). Mediation analysis. Annual Review of Psychology, 58(1), 593-614. doi:10.1146/annurev.psych.58.110405.08

MacKinnon, D. P., Lockwood, C. M., Hoffman, J. M., West, S. G., \& Sheets, V. (2002). A comparison of methods to test mediation and other intervening variable effects. Psychological Methods, 7(1), 83-104. doi:10.1037/1082-989x.7.1.83

Mallak, L. (1998). Putting organizational resilience process to work. Industrial Management, 40, 8-14.

Marsh, H. W., Balla, J. R., \& Hau, K. T. (1996). An evaluation of Incremental Fit Indices: A clarification of mathematical and empirical properties. In G. A. Marcoulides \& R. E. Schumacker (Eds.), Advanced structural equation modeling, issues and techniques (pp. 315-353). Mahwah, NJ: Lawrence Erlbaum Associates Publishers.

Martin, A. J., \& Marsh, H. W. (2006). Academic resilience and its psychological and educational correlates: A construct validity approach. Psychology in the Schools, 43(3), 267-281. doi:10.1002/pits.20149

Masten, A. S. (2001). Ordinary magic. Resilience processes in development. American Psychologist, 56(3), 227-238. doi:10.1037//0003-066X.56.3.227

Masten, A. S., \& Reed, M. J. (2002). Resilience in development. in Snyder, C.R., and Lopez, S.J. (Eds.), Handbook of positive psychology (pp. 74-88), US: Oxford University Press, New York.

Masten, A. S., Hubbard, J. J., Gest, S. D., Tellegen, A., Garmezy, N., \& Ramirez, M. (1999). Competence in the context of adversity: Pathways to resilience and maladaptation from childhood to late adolescence. Development and Psychopathology, 11(1), 143-169. doi:10.1017/s0954579499001996 
Mathieu, J. E., Maynard, M. T., Rapp, T., \& Gilson, L. (2008). Team effectiveness 1997-2007: a review of recent advancements and a glimpse into the future. Journal of Management, 34(3), 410-476. doi:10.1177/0149206308316061

MacCann, C., Fogarty, G. J., Zeidner, M., \& Roberts, R. D. (2011). Coping mediates the relationship between emotional intelligence (EI) and academic achievement. Contemporary Educational Psychology, 36(1), 60-70. doi:10.1016/j.cedpsych.2010.11.002

McCarthy, J. P. (1992). Focus from the start - employee orientation programs Orientation. HR Magazine, 37, 77-83.

McDermott, R. (1999). Learning across teams: How to build communities of practice in team organizations. Knowledge Management Journal, 8, 32-36.

McDonald, A. S. (2001) The Prevalence and Effects of Test Anxiety in School Children. Educational Psychology, 21(1), 89-101. doi:10.1080/01443410124641

Midgley, C., Maehr, M. L., Hruda, L. Z., Anderman, E., Anderman, L., Freeman, K. E., Gheen, M., Kaplan, A., Kumar, R., Middleton, M. J., Nelso, J., Roeser, R., \&Urdan, T. (2000). Manual for Patterns of Adaptive Learning Scales. University of Michigan Press.

Minolli, C. B. (2005). Empresas Resilientes. Algunas Ideas para Construirlas [Resilient Organizations. Some Ideas for build them]. Temas de Management, 3, 20-24.

Morales, E. E. (2008). The resilient mind: The psychology of academic resilience. The Educational Forum, 72, 152-167. doi: 10.1177/1538192708317119

Morgeson, F. P., \& Hofmann, D. A. (1999). The structure and function of collective constructs: Implications for multilevel research and theory development. Academy of Management Review, 24, 249-265. doi:10.2307/259081

Morgeson, F. P., \& Humphrey, S. E. (2006). The Work Design Questionnaire (WDQ): Developing and Validating a Comprehensive Measure for Assessing Job Design and the Nature of Work. Journal of Applied Psychology, 91(6), 1321-1339. doi:10.1037/0021-9010.91.6.1321

Morris, M. L., Messal, C. B., \& Meriac, J. P. (2013). Core Self-Evaluation and Goal Orientation: Understanding Work Stress. Human Resource Development Quarterly, 24(1), 35-62. doi:10.1002/hrdq.21151 
Moss, S. A., Dowling, N., \& Callanan, J. (2009). Towards an integrated model of leadership and self regulation. Leadership Quarterly, 20(2), 162-176. doi:10.1016/j.leaqua.2009.01.005

Muthén, B., \& Kaplan, D. (1985). A comparison of some methodologies for the factor analysis of non-normal Likert variables. British Journal of Mathematical and Statistical Psychology, 38(2), 171-189. doi:10.1111/j.2044-8317.1985.tb00832.x

Muthén, L., \& Muthén, B. O. (1998). Mplus user's guide. Los Angeles, CA: Muthén and Muthén.

Nelson, D., Klein, C. F., \& Irvin, J. E. (2003). Motivational Antecedents of Empathy: Inhibiting Effects of Fatigue. Basic and Applied Social Psychology, 25(1), 37-50. doi:10.1207/s15324834basp2501_3

Norris, F. H., Stevens, S. P., Pfefferbaum, B., Wyche, K. F., \& Pfefferbaum, R. L. (2008). Community resilience as a metaphor, theory, set of capacities, and strategy for disaster readiness. American Journal of Community Psychology, 41, 127-150. doi:10.1007/s10464-007-9156-6

Nunnally J. C., \& Bernstein I. H. (1994). Psychometric theory. New York: McGrawHill, Inc.

O'Bannon, D. P., \& Pearce, C. L. (1999). An Exploratory Examination of Gainsharing in Service Organizations: Implications for organizational citizenship behavior and pay satisfaction. Journal of Managerial Issues, 11(3), 363-378.

Ong, A. D., Bergeman, C. S., Bisconti, T. L., \& Wallace, K. A. (2006). Psychological Resilience, Positive Emotions, and Successful Adaptation to Stress in Later Life. Journal of Personality \& Social Psychology, 91(4), 730-749. doi:10.1037/00223514.91.4.730

Ostroff, C. (1992). The Relationship between Satisfaction, Attitudes, and Performance: An Organizational Level Analysis. Journal of Applied Psychology, 77(6), 963974. doi:10.1037/0021-9010.77.6.963

Ostroff, C. (1993). Comparing Correlations Based on Individual-Level and Aggregated Data. Journal of Applied Psychology, 78(4), 569-582. doi:10.1037/00219010.78.4.569 
Parker, C. P., Baltes, B. B., Young, S. A., Huff, R. A., Altmann, R. A., Lacost, H. A., \& Roberts, J. E. (2003). Relationships between Psychological Climate Perceptions and work outcomes: A Meta-Analytic review. Journal of Organizational Behavior, 24(4), 389-416. doi:10.1002/job.198

Paulus, P. B., \& Nijstad, B. A. (2003). Group creativity: Innovation through collaboration. New York, NY: Oxford University Press.

Perczek, R., Carver, C. S., Price, A. A., \& Pozo-Kaderman, C. (2000). Coping, Mood, and Aspects of Personality in Spanish Translation and Evidence of Convergence With English Versions. Journal of Personality Assessment, 74(1), 63-87. doi:10.1207/s15327752jpa740105

Perry, R. P., \& Magnusson, J. L. (1989). Causal attributions and perceived performance: consequences for college students achievement and perceived control in diferent instructional conditions. Journal of EducationalPsychology81: 164-172. doi: 10.1037/0022-0663.81.2.164

Ping, R. A. (1995). A Parsimonious Estimating Technique for Interaction and Quadratic Latent Variables. Journal of Marketing Research, 32(3), 336-347. doi:10.2307/3151985

Podsakoff, P. M., MacKenzie, S. B., Lee, J. Y., \& Podsakoff, N. P. (2003). Common Method Biases in Behavioral Research: A Critical Review of the Literature and Recommended Remedies. Journal of Applied Psychology, 88(5), 879. doi:10.1037/0021-9010.88.5.879

Podsakoff, P. M., MacKenzie, S. B., \& Podsakoff, N. P. (2012). Sources of Method Bias in Social Science Research and Recommendations on How to Control It. Annual Review Of Psychology, 63(1), 539-569. doi:10.1146/annurev-psych120710-100452

Powley, E. H. (2009). Reclaiming resilience and safety: Resilience activation in the critical period of crisis. Human Relations, 62(9), 1289-1326. doi:10.1177/0018726709334881

Pritchard, R. D., \& Karasick, B. W. (1973). The Effects of Organizational Climate on Managerial Job Performance and Job Satisfaction. Organizational Behavior and Human Decision Processes, 9(1), 126-146. doi:10.1016/0030-5073(73)90042-1 
Putwain, D. (2007). Researching academic stress and anxiety in students: some methodological considerations. British Educational Research Journal, 33(2), 207-219. doi:10.1080/01411920701208258

Raudenbush, S., \& Bryk, A. (2002). Hierarchical linear models: Applications and data analysis methods (2nd ed.). Thousand Oaks, CA: Sage.

Reivich, K. \& Schatte, A. (2002). The resilience factor. New York: Broadway Books.

Richardson, M., Abraham, C., \& Bond, R. (2012). Psychological correlates of university students' academic performance: A systematic review and metaanalysis. Psychological Bulletin, 138(2), 353-387. doi: 10.1037/a0026838

Richter, A. W., West, M. A., van Dick, R., \& Dawson, J. F. (2006). Boundary spanners' identification, intergroup contact, and effective intergroup relations. The Academy of Management Journal, 49, 1252-1269. doi:10.5465/AMJ.2006.23478720

Riketta, M. (2008). The Causal Relation Between Job Attitudes and Performance: a Meta-Analysis of Panel Studies. Journal of Applied Psychology, 93(2), 472-481. doi:10.1037/0021-9010.93.2.472

Riolli, L., Savicki, V., \& Richards, J. (2012). Psychological Capital as a Buffer to Student Stress. Psychology, 3(12), 1202-1207. doi:10.4236/psych.2012.312a178

Riolli, L., \& Savicki, V. (2003). Information system organizational resilience. Omega, 31(3), 227. doi:10.1016/s0305-0483(03)00023-9

Rizzo, J., House, R. J., \& Lirtzman, S. I. (1970). Role conflict and ambiguity in complex organizations. Administrative Science Quarterly, 15(2), 150-163. doi:10.2307/2391486

Roddenberry, A., \& Renk, K. (2010). Locus of Control and Self-Efficacy: Potential Mediators of Stress, Illness, and Utilization of Health Services in College Students. Child Psychiatry \& Human Development, 41(4), 353-370. doi:10.1007/s10578-010-0173-6

Rode, J. C., Arthaud-Day, M. L., Mooney, C. H., Near, J. P., Baldwin, T. T., Bommer, W. H., \& Rubin, R. S. (2005). Life Satisfaction and Student Performance. Academy of Management Learning \& Education, 4(4), 421-433. doi:10.5465/amle.2005.19086784 
Ross, S. E., Niebling, B. C., \& Heckett, T. M. (1999). Sources of stress among college students. College Student Journal, 33, 316-318.

Rousseau, D. (1995). Psychological contracts in organizations. Thousand Oaks, CA: Sage.

Ryan, A. M. (2001). The peer group as a context for the development of young adolescents' motivation and achievement. Child Development, 72(4), 1135-1150. doi:10.1111/1467-8624.00338

Salancik, G. R., \& Pfeffer, J. (1978). A social information processing approach to job attitudes and task design. Administrative Science Quarterly, 23(2), 224-253. doi: $10.2307 / 2392563$

Salanova, M. (2008). Organizaciones saludables y desarrollo de recursos humanos [Healthy Organizations and Human Resources Development]. Revista de Trabajo y seguridad Social, 303, 179-214.

Salanova, M. (2009). Organizaciones saludables, organizaciones resilientes [Healthy Organizations, Resilient Organizations]. Gestión Práctica de Riesgos Laborales, $58,18-23$.

Salanova, M., Bresó, E., \& Schaufeli, W. B. (2005). Hacia un modelo espiral de las creencias de eficacia en el estudio del burnout y del engagement [Towards a spiral model of efficacy beliefs on the burnout and engagement research]. Ansiedad $y$ Estrés, 11, 215-231.

Salanova, M., Llorens, S., Cifre, E., \& Martínez, I. M. (2012). We Need a Hero! Toward a Validation of the Healthy and Resilient Organization (HERO) Model. Group \& Organization Management, 37(6), 785-822. doi:10.1177/1059601112470405

Salanova, M., Llorens, S., \& Schaufeli, W. B. (2011). 'Yes, I Can, I Feel Good, and I Just Do It!' On Gain Cycles and Spirals of Efficacy Beliefs, Affect, and Engagement. Applied Psychology: An International Review, 60(2), 255-285. doi:10.1111/j.1464-0597.2010.00435.x

Salanova, M., Schaufeli, W., Martínez, I., \& Bresó, E. (2010). How obstacles and facilitators predict academic performance: the mediating role of study burnout and engagement. Anxiety, Stress \& Coping, 23(1), 53-70. doi:10.1080/10615800802609965 
Saridakis, G., Muñoz Torres, R., \& Johnstone, S. (2013). Do Human Resource Practices Enhance Organizational Commitment in SMEs with Low Employee Satisfaction? British Journal of Management, 24(3), 445-458. doi:10.1111/j.14678551.2012.00814.x

Scales, P. C., Roehlkepartain, E. C., Neal, M., Kielsmeier, J. C., \& Benson, P. L. (2006). Reducing Academic Achievement Gaps: The Role of Community Service and Service-Learning. Journal of Experiential Education, 29(1), 38-60. doi:10.1177/105382590602900105

Schachter, S. (1959). The psychology of affiliation. Stanford, CA: Stanford University Press.

Schein, E. H. (1993). On Dialogue, Culture, and Organizational Learning. Organizational Dynamics, 22(2), 40-51. doi:10.1016/0090-2616(93)90052-3

Schnake, M. E. (1983). An Empirical Assessment of the Effects of Affective Response in the Measurement of Organizational Climate. Personnel Psychology, 36(4), 791-807. doi:10.1111/j.1744-6570.1983.tb00513.x

Seligman, M. (2003) Authentic Happiness: Using the New Positive Psychology to Realize Your Potential for Deep Fulfilment. Nicholas Brealey, London.

Senge, P. (2006). The Fifth Discipline. Ed. Doubleday. New York.

Shin, J., Taylor, M. S., \& Seo, M. (2012). Resources for change: the relationships of organizational inducements and psychological resilience to employees' attitudes and behaviors toward organizational change. Academy of Management Journal, 55(3), 727-748. doi:10.5465/amj.2010.0325

Shrout, P. E., \& Bolger, N. (2002). Mediation in experimental and non-experimental studies: New procedures and recommendations. Psychological Methods, 7(4), 422-445. doi:10.1037/1082-989x.7.4.422

Sinclair, V. G., \& Wallston, K. A. (2004). The Development and Psychometric Evaluation of the Brief Resilient Coping Scale. Assessment, 11(1), 94-101. doi:10.1177/1073191103258144

Smith, B., Dalen, J., Wiggins, K., Tooley, E., Christopher, P., \& Bernard, J. (2008). The brief resilience scale: Assessing the ability to bounce back. International Journal of Behavioral Medicine, 15(3), 194-200. doi:10.1080/10705500802222972 
Sobel, M. E. (1988). Direct and indirect effects in linear structural equation models. In J.S. Long (Ed.), Common problems/proper solutions (pp. 46-64). Beverly Hills, CA: Sage.

Somers, S. (2009). Measuring resilience potential: An adaptive strategy for organizational crisis planning. Journal of Contingencies and Crisis Management, 17(1), 12-23. doi:10.1111/j.1468-5973.2009.00558.x

Snyder, C. R., Shorey, H. S., Cheavens, J., Pulvers, K. M., Adams, V. H., \& Wiklund, C. (2002). Hope and academic success in college. Journal of Educational Psychology, 94(4), 820-826. doi:10.1037/0022-0663.94.4.820

Spagnoli, P., Caetano, A., \& Santos, S. (2012). Satisfaction with job aspects: Do patterns change over time? Journal of Business Research, 65(5), 609-616. doi:10.1016/j.jbusres.2011.02.048

Spector, P. E. (2006). Method Variance in Organizational Research: Truth or Urban Legend? Organizational Research Methods, 9(2), 221-232. doi:10.1177/1094428105284955

Stallman, H. M. (2010). Psychological distress in university students: A comparison with general population data. Australian Psychologist, 45(4), 249-257. doi:10.1080/00050067.2010.482109

Staudinger, U. M., Marsiske, M., \& Baltes, P. B. (1993). Resilience and levels of reserve capacity in later adulthood: Perspectives from life-span theory. Development and Psychopathology, 5, 541-566. doi:10.1017/s0954579400006155

Staw, B. M., Sutton, R. I., \& Pelled, L. H. (1994). Employee positive emotion and favorable outcomes at the workplace. Organization Science, 5(1), 51-71. doi:10.1287/orsc.5.1.51

Steinhardt, M., \& Dolbier, C. (2008). Evaluation of a Resilience Intervention to Enhance Coping Strategies and Protective Factors and Decrease Symptomatology. Journal of American College Health, 56(4), 445-453. doi:10.3200/jach.56.44.445-454

Stephens, J., Heaphy, E. D., Carmeli, A., Spreitzer, G. M., \& Dutton, J. E. (2013). Relationship Quality and Virtuousness: Emotional Carrying Capacity as a Source 
of Individual and Team Resilience. Journal of Applied Behavioral Science, 49(1), 13-41. doi:10.1177/0021886312471193

Stewart, G. (2010). The past twenty years: Teams research is alive and well at the Journal of Management. Journal of Management, 36(4), 801-805. doi:10.1177/0149206310371512

Struthers, C. W., \& Perry, R. P. (1996). Attributional style, attributional retraining, and inoculation against motivational deficits. Social Psychology of Education, 1(2), 171-187. doi:10.1007/bf02334731

Suldo, S. M., Shaunessy, E., Michalowski, J., \& Shaffer, E. J. (2008). Coping strategies of high school students in an International Baccalaureate program. Psychology in the Schools, 45(10), 960-977. doi:10.1002/pits.20345

Sutcliffe, K. M., \& Vogus, T. J. (2003). Organizing for resilience. In K. S. Cameron, J. E. Dutton, \& R. E. Quinn (Eds.), Positive organizational scholarship: Foundations of a new discipline (pp. 94-110). San Francisco: Berrett-Koehler.

Tajfel, H., \& Turner, J. C. (1985). The social identity theory of intergroup behavior. In S. Worchel \& W. G. Austin (Eds.), Psychology of intergroup relations (2nd ed., pp. 7-24). Chicago: Nelson-Hall.

Totterdell, P. (2000). Catching moods and hitting runs: Mood linkage and subjective performance in professional sport teams. Journal of Applied Psychology, 85(6), 848-859. doi:10.1037/0021-9010.85.6.848

Tsui, A. S. (2013). Making Research Engaged: Implications for HRD Scholarship. Human Resource Development Quarterly, 24(2), 137-143. doi: 10.1002/hrdq.21161

Tugade, M. M., \& Fredrickson, B. L. (2004). Resilient Individuals Use Positive Emotions to Bounce Back From Negative Emotional Experiences. Journal of Personality \& Social Psychology, 86(2), 320-333. doi:10.1037/00223514.86.2.320

Van Muijen, J. J., Koopman, P., De Witte, K., De Cock, G., Susanj, Z., Lemoine, C., \& Turnipseed, D. (1999). Organizational culture: The FOCUS questionnaire. European Journal of Work and Organizational Psychology, 8(4), 551-568. doi:10.1080/135943299398168 
VandeWalle, D. (1997). Development and Validation of a Work Domain Goal Orientation Instrument. Educational and Psychological Measurement, 57(6), 9951015. doi:10.1177/0013164497057006009

VandeWalle, D., Cron, W. L., \& Slocum, J. W., (2001). The role of goal orientation following performance feedback. Journal of Applied Psychology, 86(4), 629-640. doi:10.1037/0021-9010.86.4.629

Vedhara, K., \& Nott, K. H. (1996). Psychosocial vulnerability to stress: A study of HIV-positive homosexual men. Journal of Psychosomatic Research, 41(3), 255267. doi:10.1016/0022-3999(96)00096-7

Vogus, T. J. \& Sutcliffe, K. M. (2007). Organizational resilience: towards a theory and research agenda. IEEE International Conference on Systems, Man and Cybernetics, 7-10 October, Montreal, Que: ISIC, 3418-3422.

Wagnild, G. M., \& Young, H. M. (1990). Resilience Among Older Women. Image: The Journal of Nursing Scholarship, 22(4), 252-255. doi:10.1111/j.15475069.1990.tb00224.x

Wagnild, G. M., \& Young, H. M. (1993). Development and psychometric evaluation of the Resilience Scale. Journal of Nursing Measurement, 1(2), 165-178. doi:10.3724/sp.j.1041.2008.00902

Walter, F., \& Bruch, H. (2008). The positive group affect spiral: a dynamic model of the emergence of positive affective similarity in work groups. Journal of Organizational Behavior, 29(2), 239-261. doi:10.1002/job.505

Warkentin, M. E., Sayeed, L., \& Hightower, R. (1997). Virtual teams versus face-toface teams: An exploratory study of a web-based conference system. Decision Sciences, 28, 975-996. doi:10.1111/j.1540-5915.1997.tb01338.x

Warr, P. (1990). Decision latitude, job demands, and employee well-being. Work \& Stress, 4(4), 285-294. doi:10.1080/02678379008256991

Weick, K. E. (1979). The social psychology of organizing. Reading, MA: AddisonWesley.

Weick, K. E. (1993). The Collapse of Sense making in Organizations: The Mann Gulch Disaster. Administrative Science Quarterly, 38(4), 628-652. doi:10.2307/2393339 
Weiss, H. M. (2002). Deconstructing job satisfaction: separating evaluations, beliefs and affective experiences. Human Resources Management Review, 12(2), 173194. doi:10.1016/s1053-4822(02)00045-1

Werner, E. \& Smith, R. (1982). Vulnerable but invincible: A study of resilient children. New York: McGraw-Hill.

West, B. J., Patera, J. L., \& Carsten, M. K. (2009). Team level positivity: investigating positive psychological capacities and team level outcomes. Journal of Organizational Behavior, 30, 249-267. doi:10.1002/job

Whitman, D. S., Van Rooy, D. L., \& Viswesvaran, C. (2010). Satisfaction, Citizenship Behaviors, and Performance in Work Units: A Meta-Analysis of Collective Construct Relations. Personnel Psychology, 63(1), 41-81. doi:10.1111/j.17446570.2009.01162.x

Wildavsky, A. (1988). Searching for safety. New Brunswick, NJ: Transaction Books.

Wolin, S. J., \& Wolin, S. (1993). Bound and determined: Growing up resilient in a troubled family. New York: Villard.

Wright, T. A., Cropanzano, R., \& Meyer, D. G. (2004). State and Trait Correlates of Job Performance: A Tale of Two Perspectives. Journal of Business \& Psychology, 18(3), 365-383. doi: 10.1023/b:jobu.0000016708.22925.72

Xanthopoulou, D., Bakker, A. B., Demerouti, E., \& Schaufeli, W. B. (2009). Reciprocal relationships between job resources, personal resources, and work engagement. Journal of Vocational Behavior, 74(3), 235-244. doi:10.1016/j.jvb.2008.11.003

Yeo, R. (2002). From Individual to Team Learning: Practical Perspectives on the Learning Organization. $M C B \quad U P$ Limited, 8(7-8), 157-170. doi:10.1108/13527590210442221

Youssef, C. M., \& Luthans, F. (2005). Resiliency development of organizations, leaders and employees: Multi-level theory building for sustained performance. In W. Gardner, B. J. Avolio, \& F. O. Walumbwa (Eds.), Authentic leadership theory and practice. Origins, effects, and development (pp. 303-343). Oxford, UK: Elsevier.

Youssef, C. M., \& Luthans, F. (2007). Positive organizational behavior in the workplace. The impact of Hope, Optimism and Resilience. Journal of Management, 33(5), 774-800. doi:10.1177/0149206307305562 


\section{RESUMEN}

El principal objetivo de la presente tesis doctoral es aportar valor añadido a la corriente de investigación sobre resiliencia, avanzando en la comprensión actual de la misma a través de la evidencia teórica y empírica de su papel fundamental en el contexto organizacional. Este objetivo se ha operacionalizado en el planteamiento de diferentes preguntas de investigación en función de las necesidades actuales, tanto de la investigación como sociales, que se han planteado organizándose en los siguientes tres retos de investigación:

RETO 1. ¿Cómo puede ser conceptualizada la resiliencia en el contexto de la organización? Además del enfoque tradicional en la resiliencia individual, ¿vale la pena centrarse en la resiliencia de los equipos o de los grupos?

RETO 2. ¿Cuáles son los antecedentes de la resiliencia en el contexto organizacional? Además de los antecedentes de tipo personal, ¿existen características situacionales que ayudan a mejorar la resiliencia? Además, ¿pueden los antecedentes conceptualizarse en diferentes niveles?

RETO 3. ¿Cuál es el impacto real de la resiliencia en el contexto de la organización? ¿Persigue el objetivo de lograr un mejor rendimiento?

Para tratar de responder a estos retos de investigación, la tesis está compuesta por un capítulo teórico (Capítulo 2) y cuatro estudios empíricos (Capítulos 3-6), enmarcados por la introducción general (Capitulo 1) y las conclusiones finales (Capitulo 7). Mientras que en el capítulo teórico se ha llevado a cabo una revisión de la literatura relevante sobre resiliencia en el contexto organizacional y evidenciado unos vacíos de conocimiento detectados en la literatura, los cuatro capítulos empíricos se han centrado en ahondar en estos vacíos para responder a las preguntas de investigación. Específicamente, los dos primeros estudios empíricos (Capítulos 3 y 4) arrojan luz sobre la resiliencia conceptualizada a nivel de equipo, mientras que en los otros dos estudios empíricos (Capítulos 5 y 6) el foco se desplaza a la resiliencia de los individuos que componen las organizaciones (es decir, la resiliencia individual). A lo largo de todos los capítulos empíricos, se han analizado antecedentes significativos de la resiliencia, así como posibles resultados o consecuencias. Con respecto al método, los cuatro estudios empíricos se han realizado en diversos contextos organizacionales (es decir, pequeñas y medianas empresas, grandes empresas de servicio y en las organizaciones educativas) así como en diferentes países (es decir, España e Italia). Además, se han utilizado 
diferentes métodos estadísticos (por ejemplo, análisis factorial exploratorio, análisis factorial confirmatorio, validación de la escala, modelos de ecuaciones estructurales, análisis multinivel) para poner a prueba las hipótesis de los estudios.

Teniendo en cuenta las posibles limitaciones de la tesis y sugiriendo futuros estudios dirigidos a indagar la importancia de la resiliencia en el contexto organizacional, consideramos que los resultados encontrados tienen importantes implicaciones prácticas y teóricas para el estudio de cómo las organizaciones, así como las personas y los equipos que las componen, son capaces de ajustarse con éxito y prosperar en condiciones adversas. Especialmente en la situación socioeconómica actual, caracterizada por la crisis económica y la recesión global, creemos que estos resultados son muy beneficiosos y valiosos tanto para la investigación como para la sociedad. 


\section{RIASSUNTO}

L'obiettivo principale di questa tesi dottorale è quello di contribuire significativamente alla ricerca attuale sulla resilienza, promovendo la sua comprensione attraverso evidenza teorica ed empirica del suo ruolo chiave nel contesto organizzativo. Per compiere questo obiettivo, sono state formulate molteplici domande di ricerca, basate sulle attuali esigenze della ricerca e sociali, che sono state poi organizzate nei tre seguenti research challenges:

CHALLENGE 1. Come si può concettualizzare la resilienza nel contesto organizzativo? Oltre alla tradizionale attenzione sulla resilienza individuale, vale la pena concentrarsi sulla resilienza dei team e dei gruppi?

CHALLENGE 2. Quali sono gli antecedenti della resilienza nel contesto organizzativo? Oltre agli antecedenti di tipo personale, è rilevante considerare antecedenti situazionali per migliorare la resilienza? Inoltre, la resilienza può essere concettualizzata a diversi livelli?

CHALLENGE 3. Qual è l'impatto reale della resilienza nel contesto delle organizzazioni? È rilevante per ottenere migliori prestazioni?

Per cercare di rispondere a questi research challenges, la tesi è costituita da un capitolo teorico (capitolo 2) e quattro studi empirici (capitoli 3-6), incorniciati dalla introduzione generale (capitolo 1) e le conclusioni finali (Capitolo 7). Mentre nel capitolo teorico si ha realizzato una revisione della letteratura rilevante per la resilienza nel contesto organizzativo, mettendo in evidenza alcune lacune di conoscenza individuate nella letteratura, i quattro capitoli empirici si sono concentrati nell'approfondimento di queste lacune per soddisfare le domande di ricerca. In particolare, i primi due studi empirici (Capitoli 3 e 4) propongono risultati sulla resilienza concettualizzata a livello di team, mentre negli altri due studi empirici (Capitoli 5 e 6) l'attenzione si sposta verso la resilienza degli individui che compongono le organizzazioni (cioè la resilienza individuale). Nel corso di tutti i capitoli che presentano studi empirici, sono stati analizzati antecedenti significativi della resilienza e possibili outcomes o conseguenze. In referenza al metodo utilizzato, i quattro studi empirici sono stati realizzati in diversi contesti organizzativi (ad esempio, piccole e medie imprese, grandi imprese e organizzazioni scolastiche), così come in diversi paesi (ad esempio, Spagna e Italia). Inoltre, sono stati utilizzati diversi metodi statistici (ad esempio, analisi fattoriale esplorativa, analisi fattoriale confermativa, validazione della 
scala, modelli di equazioni strutturali, analisi multilivello) per verificare le ipotesi di ricerca proposte.

Nonostante le potenziali limitazioni della tesi ed i suggerimenti per studi futuri destinati a indagare l'importanza della resilienza nel contesto organizzativo, riteniamo che i risultati di questa tesi hanno importanti implicazioni pratiche e teoriche per lo studio di come le organizzazioni, così come gli individui ed i gruppi che le compongono, sono in grado di adattarsi con successo e prosperare in condizioni avverse. Soprattutto nelle condizioni socio economiche atuali, caratterizzate dalla crisi economica e da una recessione globale, riteniamo che questi risultati siano molto utili e di valore sia per la ricerca che per la società. 


\section{AGRADECIMIENTOS}

De la misma forma en que la investigación nos enseña que las relaciones interpersonales son centrales para el desarrollo de la resiliencia, hay muchas personas que han contribuido al desarrollo de mi propia resiliencia en las etapas más y menos felices de la realización de esta tesis. La elaboración de la misma no habría sido posible sin el apoyo de todas estas personas, y algunas otras que me han alentado y asistido durante la elaboración de la tesis y su corrección, a las que estoy muy agradecida.

En primer lugar quiero dar las gracias a mis Directoras de tesis por haber confiado en mí y haberme dado la oportunidad de emprender mi camino en el mundo de la investigación. En los primeros pasos de este camino vuestra guía ha sido imprescindible para mí, y aún lo sigue siendo of course, pero también os quiero agradecer la autonomía, confianza y el espacio a mi iniciativa que me habéis ido proporcionando in crescendo a lo largo de este proceso. Gracias Isabel, por haber sido mi persona de referencia desde el principio, sin apenas conocerme. En estos años has sido constantemente mi contacto con la realidad, con tu espíritu práctico y tu gran corazón me has alentado siempre a dar lo mejor de mí sin perder de vista las cosas más importantes y sabiendo que podía contar contigo para todo. Gracias Marisa, por haber sido fuente persistente de motivación a lo largo de estos años, por haber sido capaz de encontrar las palabras para estimular mi crecimiento y desarrollo en los momentos buenos y también, muy necesario, en los más duros. Tu optimismo y entusiasmo me has contagiado muchísimas veces y me has servido como inspiración para seguir perseverando hacía mis objetivos.

Sin embargo, mi camino en el WoNT no habría sido el mismo sin mis queridas y queridos wonters, personas de una calidad humana y profesional inestimable. Compañeros de muchas experiencias y de gran aprendizaje, cómplices en los buenos momentos vividos entre los despachos y el F2F, en los congresos y en todas las actividades extra laborales que he tenido la suerte de compartir con vosotros. Gracias por todos esos momentos wonters, gracias a los que me han acompañado desde el principio y siguen aquí, a los que han emprendido su camino hacia otros parajes, a los que han llegado más recientemente y a todos los que han compartido períodos breves pero igualmente felices. En especial quiero mencionar los tres wonters que para mí han sido mucho más que compañeros durante este camino. Vale, mi Compi por antonomasia, gracias por ser la amiga y el apoyo incondicional con el que contar 
siempre y en todas las circunstancias. Gracias por tu sensibilidad, generosidad y positividad. Nuestro vínculo de amistad va mucho más allá de las paredes del despacho que hemos compartido desde el primer momento. Món, posiblemente la persona más bondadosa que haya conocido jamás, gracias por tener siempre el tiempo y las ganas de compartir conmigo tu curiosidad y el amor por el conocimiento, así como las muchas carcajadas. Isra, cómplice en muchos momentos importantes, gracias por estar cuando lo necesito, por creer en mis capacidades y en mi trabajo, animándome constantemente para alcanzar lo mejor. Gracias, amigos mios.

I also want to thank Laura Borgogni and Hans de Witte for giving me the opportunity to join your research groups during my research stays in Rome and Leuven, respectively. I really enjoyed the time that I spent with you. I am also really grateful for your warm welcome and the work we developed together during those months, and afterwards. I feel that both research stays helped me to further develop professionally and as a person. Definitely, that was possible because you. Grazie mille, Laura! Dank je wel, Hans! Thanks for being part of my doctoral apprenticeship.

Un ringraziamento speciale va fatto a tutti i miei affetti in Italia, ai miei amici e a tutta la mia famiglia, però in particolare ai miei genitori Denise e Giuseppe per aver sempre creduto in me ed avermi appoggiato senza eccezione in ogni mia scelta. Siete state voi le persone che mi hanno insegnato a dare i primi passi e mi hanno dato la fiducia necessaria per poter intraprendere il mio cammino in autonomia. E grazie ai miei fratelli, Alby e Linda, per essere partecipi del mio progetto e assecondare con orgoglio i miei obiettivi. Come sorella maggiore, sono tanto orgogliosa di voi e delle meravigliose persone che siete e state diventando. A voi quattro, che con il vostro amore siete il mio punto fermo, non importa la distanza fisica che ci separa, semplicemente grazie.

Finalmente, quiero agradecer a la persona que incluso desde antes del comienzo de mi tesis ha creído en mí y en mis aspiraciones, me ha incitado a perseguir mis objetivos y me ha acompañado cada día y cada noche durante todo el camino. Gracias Álex por estar en todos los momentos que han marcado este camino, por comprender y apoyarme de manera incondicional, por tu insustituible presencia siempre. Pero sobre todo gracias por la maravillosa persona que eres, por nuestro grande amor y por hacer que mi vida sea aún más feliz al estar a tu lado. A te che sei, semplicemente sei, compagno dei giorni miei, sostanza dei sogni miei. 
